\title{
THE RECOVERY PROJECT: THREE DRAMATIC WORKS CONCERNING ALCOHOLISM AND RECOVERY
}

A Dissertation

Presented to

The Faculty of the Graduate School

At the University of Missouri

In Partial Fulfillment

Of the Requirements for the Degree

Doctor of Philosophy

By

AARON MICHAEL SCULLY

Dr. David A. Crespy, Dissertation Supervisor

May 2018 
(C) Copyright 2018 by Aaron Michael Scully

All rights reserved 
The undersigned, appointed by the dean of the Graduate School, have examined the Dissertation entitled

THE RECOVERY PROJECT: THREE DRAMATIC WORKS CONCERNING ALCOHOLISM AND RECOVERY

Presented by Aaron Michael Scully

A candidate for the degree of

Doctor of Philosophy

And hereby certify that, in their opinion, it is worthy of acceptance.

Dr. David A. Crespy

Dr. Cheryl Black

Dr. Kevin Brown

Dr. Wayne Breckhus 


\section{DEDICATION}

To all alcoholics who are suffering - may you find peace 


\section{ACKNOWLEDGEMENTS}

Dr. David Crespy - I could not have done this without you. Your guidance and encouragement made this dissertation possible. Thank you for believing enough in my skills as both a scholar and playwright to take a chance on this dissertation. Your incredibly vast knowledge of dramatic writing and your unwavering belief in its power will forever inspire me. Somehow, you knew when to be patient and when to push. Your mentorship and friendship mean the world to me. I will never be able to thank you enough, Dr. Crespy.

Dr. Cheryl Black - I am continually awestruck by your intelligence and talent. Thank you for teaching me how to "make it matter." Your love of theatre history is infectious. I could spend hours talking to you about the moments, events, people and movements that have brought us to our present point. You have taught me so much. I am especially grateful for teaching me how to be a better writer. Thank you, Dr. Black.

Dr. Kevin Brown - Your Performance Ethnography class came along right at the right moment. The safe environment you provided for me to be open and honest about my recovery was a pivotal moment in the evolution of this dissertation. Thank you for your mentorship and friendship and challenging me to set aside my reservations about exploring the culture of recovery. Without that, I'm not sure this dissertation would be what it is - something profoundly personal that helped me to learn as much about myself as about others. For that, and much more, thank you.

Dr. Wayne Breckhus - Thank you for guiding me on my journey through identity theory. The knowledge I gained had a profound impact not only on this dissertation, but on me as well. I learned a great deal about how important of a factor recognition of identity is for a recovering 
alcoholic. More importantly, though, you helped me to gain a better understanding of who I am and for that I will remain forever grateful.

\author{
Dr. Richard (Buzz) Herman, Dr. Julie Rae Mollenkamp and John Wilson - University of \\ Central Missouri Theatre and Dance Faculty - You all gave me the foundation I needed to be \\ successful in my doctoral studies. You ingrained in me a love of theatre scholarship that will \\ remain with me always. You made me a better artist, scholar and person. I will forever cherish \\ our friendship and feel incredibly blessed to be your colleague.
}

Amy Mickelson - Thank you for being an inspiration in the crucial final days of completing this dissertation. You were truly a Godsend. Your suggestions, editing and proofreading took the quality of this dissertation to a whole new level. I sure am lucky to have you as a friend. Thank you, Amy!

Robin Scully and Katie Scully - my parents - your continual love and support through everything is all a son could ever ask. You NEVER gave up on me. You instilled an appreciation for education which has made me a lifelong learner. You taught me empathy, which, for a playwright, may be the greatest gift of all. I love you, Mom and Dad.

Ashley Miller-Scully - To my wife, thank you for your patience. Thank you for allowing me to hide and write for hours on end. Thank you for dealing with a long-distance relationship while I went off to school. Thank you for always supporting my dreams. I love you. You make everything worth it. 


\section{TABLE OF CONTENTS}

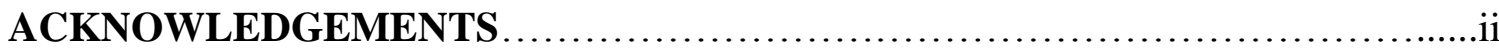

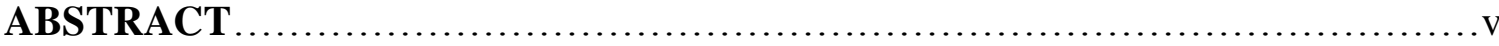

Chapter 1: Introduction.................................................

Chapter 2: Purpose, Literature Review, and Methodology ......................16

Statement of Purpose..................................................... 16

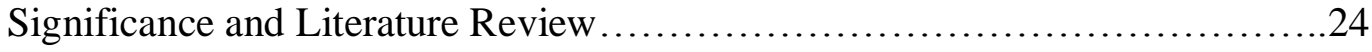

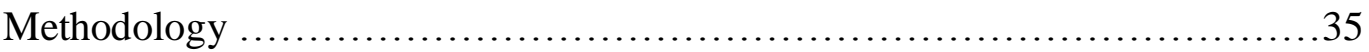

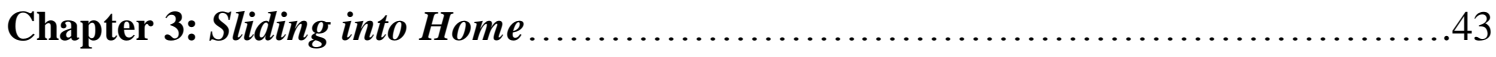

Introduction......................................................... 43

Sliding into Home: A Play in Two Acts..................................52

Chapter 4: The Disappointments ........................................ 133

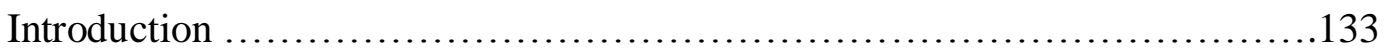

The Disappointments: A play ....................................... 143

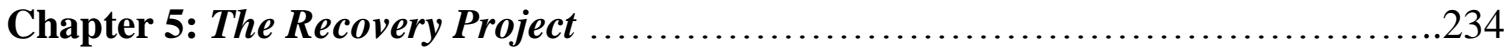

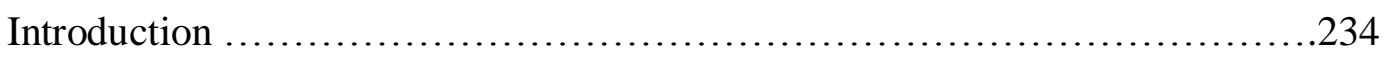

The Recovery Project: An Ethnographic Performance Text ..................243

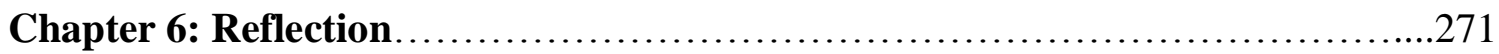

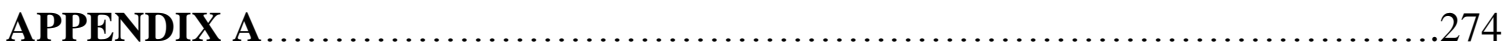

The Twelve Steps of Alcoholics Anonymous ..............................2274

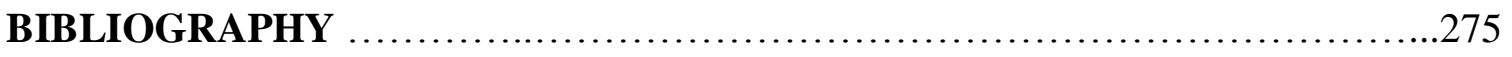

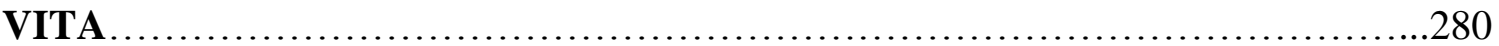




\title{
THE RECOVERY PROJECT: THREE DRAMATIC WORKS CONCERNING ALCOHOLISM AND RECOVERY
}

\author{
Aaron Michael Scully \\ Dr. David A. Crespy, Dissertation Supervisor
}

\begin{abstract}
This dissertation explores the transformative nature of storytelling in alcoholism recovery. I created a trilogy of dramatic works titled The Recovery Project, which address the underrepresented narrative of recovery through my personal experience with alcoholism recovery, and the experiences of others. The three plays, Sliding into Home, The Disappointments, and The Recovery Project are not a trilogy in the traditional sense; rather they represent the three stages in the life of a recovering alcoholic: active alcoholism, acceptance of a problem, and recovery.

Sliding into Home is a family tragedy told with a non-linear structure. The Disappointments is a semi-autobiographical inspired work about my journey through treatment. The final play, The Recovery Project is an ethnographic performance text. I conducted interviews with several people who have differing lengths of sobriety. Based on these interviews, I wrote a non-fiction narrative about finding recovery.

Each dramatic work is prefaced with an introduction that describes the inspiration for each play, my personal connection to each work, their specific purpose, dramatic techniques utilized, their evolution, their development and possibilities for the future of each play. A variety of dramatic techniques including magical realism, stage realism, and performance ethnography informs the narrative structure of each play. The purpose of these plays is to aid in the understanding of alcoholism and recovery.
\end{abstract}


"Stories are a communal currency of humanity."

- Tahir Shah in Arabian Nights

"The feeling of having shared in a common peril is one element in the powerful cement which binds us."

-Alcoholics Anonymous

"This guy's walking down the street when he falls in a hole. The walls are so steep he can't get out. A doctor passes by and the guy shouts up, 'Hey you. Can you help me out?' The doctor writes a prescription, throws it down in the hole and moves on. Then a priest comes along and the guy shouts up, 'Father, I'm down in this hole can you help me out?' The priest writes out a prayer, throws it down in the hole and moves on. Then a friend walks by, 'Hey, Joe, it's me can you help me out?' And the friend jumps in the hole. Our guy says, 'Are you stupid? Now we're both down here.' The friend says, 'Yeah, but I've been down here before and I know the way out."'

-The West Wing, Aaron Sorkin

God grant me the serenity to accept the things I cannot change; courage to change the things I can; and the wisdom to know the difference.

-The Serenity Prayer 


\section{Chapter 1: Introduction}

This dissertation is built upon a foundation of the power of storytelling. The idea that stories can change the world gives this dissertation its purpose. As a recovering alcoholic, I owe my life to the power of storytelling because without stories I would not have recovered and without recovery I would have nothing; not my family, my friends, my career, my life. I certainly would not be writing this dissertation. Rather, as they say in recovery, "I would be in an institution, jail, or dead." It is the sad truth. I was given a second chance at life; therefore, I feel a certain debt is owed to the recovery that allowed me this life. In an attempt to pay that debt (which can never really be repaid, and most would say is not even owed) I write stories, using my chosen medium of drama, which I hope will help others. I utilize my personal experiences, the experiences of others, inspiration from other playwrights, sociological studies on alcoholism and identity, different dramatic techniques including magical realism, stage realism and performance ethnography, and, perhaps most importantly, creativity, to generate dramatic work that addresses/explores the subjects of alcoholism and recovery. To provide a model of exploration for others, I examine alcoholism recovery through a lens of relational identity theory. In doing so, I authored three dramatic works that converse with each other but may also exist separately.

Storytelling is generally acknowledged as a means for personal, and collective, identify formation as well as affirmation and reconciliation. "Storytelling is a sharing experience. When we tell, we show our willingness to be vulnerable, to expose our deepest feelings, our values. That kind of nakedness that says we care about what we are 
relating invites children [people] to listen with their minds and hearts." ${ }^{1}$ When considering the assertion that stories can help an alcoholic or those associated with alcoholics, questions as to the efficacy of such method is a legitimate concern. The simplest way to address this concern is to tell a story; a true story that anyone associated with or interested in recovery from alcoholism would benefit from knowing.

One evening in 1935, at the Mayflower Hotel in Akron, Ohio, Bill Wilson wanted a cocktail. He had completed his work for the day and sat alone in the hotel lobby. Bill stirred as he sat and watched the conviviality among the people drinking at the bar. He desperately wanted to join them. There was a problem though; Bill Wilson was an alcoholic and was trying to stay sober. The length of his sobriety at the time was the longest since he had first picked up a drink over twenty years prior and he desperately did not want to relapse. However, the pull of the alcohol combined with the joy of the bar patrons was more than he could handle. As he felt himself being drawn to the drinking, laughing people at the bar, an idea struck him like a lightning bolt: he wanted to talk to another alcoholic. He was not sure why, but his instincts told him it might help. In any case, it seemed like a better idea than taking a drink.

Bill frantically ducked into the closest phone booth and scoured the phone book for possibilities. He contacted the local Oxford Group and asked if they knew of any alcoholics with which he could talk. The person gave him a list of names and numbers. Bill called all of them until he finally reached the residence of Dr. Bob Smith. Though apprehensive, the doctor agreed to allow Bill to come over for a brief chat. Bill arrived at his house and the two men sat down. The doctor planned on meeting with the stranger for

\footnotetext{
1 Ellin Greene, Janice M. Del Negro, Storytelling: Art and Technique (Libraries Unlimited: Santa Barbara, CA, 2010), 42.
} 
no more than fifteen minutes, but that was not to be the case. For hours, the two men traded stories of their drinking days and their failed and successful attempts at sobriety. Through this storytelling, a lifelong friendship developed. Not only that, but something even greater happened — something that would aid in the recovery of millions of alcoholics.

Bill ended up being right, visiting with another alcoholic helped. His conversation with the doctor momentarily alleviated his desire to drink. The doctor, after talking with Bill, felt better about his sobriety than ever before. By telling stories to each other they realized they understood each other; that they were not alone. The meeting of these two men would come to be considered the first meeting of Alcoholics Anonymous. Dr. Bob Smith would come to be known as Dr. Bob and Bill Wilson as Bill W., the founders of Alcoholics Anonymous, better known as AA. ${ }^{2}$ Alcoholics have been meeting and telling their stories ever since. The latest report of the General Service Office of AA announced that in 2016 there were over 2 million members of AA worldwide. ${ }^{3}$ This statistic provides evidence of the efficacy of AA. If it did not work, why would so many join and why would it have lasted so long?

Prior to moving forward, it should be stated that Alcoholics Anonymous and Twelve-Step Programs are not the only means to recovery. Many other programs and treatments do exist, and I am not here to discount the effectiveness of any alternative treatment. "Alcoholics Anonymous, a singularly valuable grassroots organization ... has become an important part of sobriety for many people. But twelve-step recovery is not

${ }^{2}$ Michael Fitzpatrick. Dr. Bob and Bill W. Speak: AA's Cofounders Tell their Stories (Center City: Hazeldon, 2012), 65-67.

${ }^{3}$ AA. Org. specifically: https://www.aa.org/assets/en_US/smf-53 en.pdf, Accessed April 4, 2018. 
the only approach to substance dependence, and it is certainly not sufficient, or even helpful, for everyone."4 Alcoholics Anonymous worked for myself and many of the people who influenced the writing these plays; therefore, it follows, that AA is a determining component of this dissertation.

Stories are everywhere. Every human being possesses his or her own story. Each day, each moment is a story. Stories are told so our conscious selves can make sense of the world and so people can attempt to make sense of others. In Bert O. States book Dreaming and Storytelling, he proposes that the very nature of consciousness is storytelling; human beings are narrative machines, so much so, that our minds continue to tell stories as we sleep. Additionally, he surmises our ability to craft our own stories, to change our stories, is key to our survival, as storytelling and narrative were, and are, crucial to our evolution as human beings. ${ }^{5}$

In recovery, it is suggested an alcoholic share his or her story, so they can make sense of their disease. Writer and historian Cody Delistraty states the following about why humans tell stories:

Stories can be a way for humans to feel that we have control over the world. They allow people to see patterns where there is chaos, meaning where there is randomness. Humans are inclined to see narratives where there are none because it can afford meaning to our lives - a form of existential problem-solving. Stories can also inform people's emotional lives. Storytelling . . . allows people to peek into someone's conscience to see how other people think. This can affirm our own beliefs and perceptions, but more often, it challenges them. ${ }^{6}$

Storytelling/narration helps people to make sense of the world, as well as possibly

${ }^{4}$ Leslie Jamison, The Recovering: Intoxication and its Aftermath (Little, Brown and Company, New York. 2018), 449.

5 Bert O. States, Dreaming and Storytelling, (Cornell University Press: Ithaca, NY. 1991), 187-2014.

6 Cody C. Delistraty, "The Psychological Comforts of Storytelling." The Atlantic. November 02, 2014. https://www.theatlantic.com/health/archive/2014/11/the-psychological-comforts-of-storytelling/381964/ Accessed March 3, 2018. 
challenging their beliefs; therefore, it is no accident that storytelling found its way into the process of alcoholism recovery. Until Bill W. and Dr. Bob told their stories to each other and then decided to share their stories with others, no other treatment for alcoholism came close to the success of Alcoholics Anonymous. ${ }^{7}$ The Alcoholics Anonymous' signature text, titled Alcoholics Anonymous, also known as "The Big Book," is a primary source that, in addition to its content on recovery, provides fifty autobiographical stories from alcoholics who found recovery in AA. This exemplifies the importance the AA founders and subsequent AA leadership placed on the power of narrative in recovery. ${ }^{8}$

Though Alcoholics Anonymous possesses many facets, the core of AA works through narrative. Some members of AA could possibly argue this point—for some it may be the working of the twelve steps, and for others their newly found spiritual awareness. Nevertheless, narratives are an integral aspect of the Alcoholics Anonymous program. The first step of AA is "We admitted we were powerless over alcohol - that our lives had become unmanageable." 9 This first step becomes the beginning of the next chapter of the alcoholic's personal narrative - a shift in his/her identity. If that admittance is not made, the new chapter cannot begin, and the alcoholic's life will remain in its current chapter. If no change is made, the alcoholic's life will end, most likely, in tragedy, and a chapter rooted in sobriety will never start. Also note the use of the pronoun "We" instead of "I." This is significant in the narrative of sharing admittance, or, in other

${ }^{7}$ For example, : www.hazelden.org/web/public/vcsum0research.page or https://www.scientificamerican.com/article/does-alcoholics-anonymous-work/

8 Alcoholics Anonymous: The Story of How Many Thousands of Men and Women Have Recovered from Alcoholism, 4th Edition, (Alcoholics Anonymous World Services, Inc.: New York City. 2001), 182- 559.

9 Ibid, 59. 
words, taking the first step with other members of AA and realizing an individual's story is part of a larger narrative, thus creating a sense of belonging and comfort in the recovering alcoholic.

The second step in the AA program states, "Came to believe that a power greater than ourselves could restore us to sanity." 10 Note in this step the wording "Came to believe." It does not say "Must believe" it states, "Came to believe." Bill W. and Dr. Bob and the other contributors to the "The Big Book" understood that our lives are a continuous narrative - that a struggling alcoholic does not show up at a meeting and automatically change their belief system and/or behaviors. A newcomer in AA shares their story, listens to the story of others, and then chooses how to "believe." In other words, recovery is a process. That process is a story, thus making recovery a dynamic narrative that unfolds in the alcoholic's life.

At the beginning of every AA meeting, the first few paragraphs of Chapter Five of the AA Big Book are read. The chapter is called "How it works." It is read at every meeting in case a newcomer happens to be there and wants to know what AA is all about. In the second paragraph of the passage it states: "Our stories disclose, in a general way, what we used to be like, what happened, and what we are like now." 11 During the meetings, each AA member is asked to share what they used to be like when they were actively drinking, what they did to recover, and what their life is like in recovery. In other words, they are asked to share their story. With this sharing, AA members learn about each other, they learn what they can do to stay sober; they become aware they are not alone, and perhaps most importantly, they realize, or are reminded that there is hope for a

\footnotetext{
10 Alcoholics Anonymous, 59.

11 Ibid, 58.
} 
better life.

Simply put, one of the reasons AA is effective is because of its engagement with storytelling. However, I am not on a mission to prove that AA works. AA's success rate, or people who achieve long term sobriety, is around eight to twelve percent for people who join. Therefore, considering that since Bill W. and Dr. Bob met millions of people who joined AA, this means hundreds of thousands of men and women around the world have been aided by AA in their pursuit of recovery. ${ }^{12}$ Since I argue that AA works because of its incorporation of narrative creation; I wrote dramatic works, which might act as an additional tool for the alcoholic seeking recovery.

Given the importance and inherent nature of narrative in the life of a recovering alcoholic, it seems a practical step to utilize playwriting as an additional tool to aid in that recovery. This is not a new idea. With every play written and/or performed that concerns itself with an aspect of alcoholism, more awareness and insight into the disease is created. In $19^{\text {th }}$ century America, prior to television and film, alcoholism was addressed in popular culture as part of a social movement for temperance, which sought to curtail the rising effects alcoholism was having on American culture. In this pre-Realism, melodramasaturated theatrical era, the subject of alcoholism in theatre was addressed from the sidelines, holding the alcoholic at a distance, actively treating alcoholic characters as the "other," or people who were outside what was considered "normal" society. However, during the $20^{\text {th }}$ century and leading into present day, playwrights explored more personal stories, which included alcoholism as either a plot device, character trait, or thematic

\footnotetext{
12 From AmericanAddictionCenters.org. Within the text, it explains that quantifying the success of AA is difficult. Around $10 \%$ is also given as is 1 in 15 . This data suggests that over the years at least 10 million people have tried AA and of those, at least 1 million people have found recovery. Since AA is an anonymous organization, however, any quantifiable data is subject to question.
} 
element.

For many playwrights who write about alcoholism, deeply personal reasons can influence their choice to examine the subject. Some playwrights may simply use alcoholism for dramatic purposes; however, others utilize playwriting to come to grips with their own alcoholism, to explore and accept a troubled family history, or as a medium to share their personal perspective. For years, playwrights have exhibited their own understanding of alcoholism for various reasons. Eugene O’Neill wrote about his family's history of alcoholism and addiction in Long Day's Journey into Night. O'Neill, himself was an alcoholic. He quit drinking in 1939 prior to writing his Pulitzer winning autobiographical tragedy. In that same year, Susan Glaspell "conducted a battle in Chicago, not with the city, but with the alcoholism that she had not gotten completely under control." 13 She won the battle and was sober from 1939 onward. Lillian Hellman, a popular $20^{\text {th }}$ century playwright and screenwriter said success and drinking were the reasons she began therapy. ${ }^{14}$ Tennessee Williams was an alcoholic. Alcohol and alcoholism was prevalent in many of his works. Williams never found sobriety, nor did he try. Edward Albee was an alcoholic as well, saturating his play Who's Afraid of Virginia Woolf? with drinking. However, upon achieving sobriety, Albee refrained from the overt inclusions of drinking that epitomized much of Who's Afraid of Virginia Woolf? Lanford Wilson, a Missouri playwright, struggled with alcoholism throughout his life and it figures very strongly into several of his plays.

Alcoholism is an ingrained, permanent thread of American society; therefore,

\footnotetext{
13 Linda Ben-Zvi, Susan Glaspell: Her Life and Times (Oxford University Press: New York, NY, 2005), 372

14 Alice Kessler-Harris, A Difficult Woman: The Challenging Life and Times of Lillian Hellman (Bloomsbury Press, New York, NY, 2012), 53.
} 
playwrights whose work attempts to mirror current culture would be remiss to ignore alcoholism's penetration into American culture. Some contemporary playwrights who have utilized alcoholism or addiction in their plays include Stephen Adley Giurgis, Quiara Alegria Hudes, Paula Vogel, and Duncan Macmillan. Playwrights will write about alcoholism as long as alcoholism continues to be a major social issue.

Alcoholics are said to be "children of chaos." 15 Many playwrights create order out of chaos. Sam Smiley explains this concept well in his book Playwriting: The Structure of Action:

Playwrights tend to create form in the disorder of existence. In daily life, focused unity is impossible, and so writers often reject what they see and reconstruct through their personal vision a substitute universe in their art. For that material space, and time, they destroy some of the worlds' confusion. Artists don't want to end the world; they wish to create it. ${ }^{16}$

Chaos is a common theme for an active alcoholic, both internally and externally. In AA's first step, alcoholics admit that "our life has become unmanageable." Their internal self struggles to alleviate the cognitive dissonance that consumes them. An active alcoholic is in a constant state of attempting to justify his/her actions; the alcoholic recognizes there is chaos and is usually quick to blame this chaos on everything but his/her own actions.

Depending on the degree and length of an alcoholic's addiction, there is a good possibility the alcoholic's external life is in disarray. There are usually strained, if not broken relationships, unpaid bills, problems at work, disappointed children - the list is endless. Most of these external problems cause conflict, thus making them ripe for dramatic writing. Presenting this conflict onstage may be "good" theatre, but for an

15 Twelve Steps and Twelve Traditions (Alcoholics Anonymous World Services, Inc, 2014), 146.

${ }^{16}$ Sam Smiley, Playwriting: The Structure of Action, (Yale University Press: New Haven and London, 2005), 4. 
afflicted playwright, such as myself, writing about alcoholism serves another purpose; it compartmentalizes the chaos. The hope is audiences who see plays about alcoholism and recovery understand their disease better because they get to see it organized for them. Perhaps if they recognize their own life in the play, they may be able to see a way out of it.

So, why me? Why do I think I can write plays about alcoholism that will be impactful and important? I am no Eugene O'Neill or Tennessee Williams, nor I do claim to possess a tenth of their skill level. I have had a few productions of some plays. I am at the nascent stage of professional career as a playwright. I am a teacher and scholar who writes plays, sometimes acts and sometimes directs. I am, however, a "professional" recovering alcoholic with impeccable credentials.

My own drinking days lasted for over twenty years. I got drunk for the first time when I was twelve years old and; from that point on, I never stopped trying to get drunk. I got fired from jobs. I went to multiple rehabilitations. I was arrested several times. I almost died when my liver stopped working. While in the hospital, the doctor told me that one more pint would have killed me. A near-death experience did not stop me. I relapsed about three months after my hospital stay. Soon after, I was arrested and charged with my third DUI and went to prison for five months. After prison, I had a four-year stint of sometimes happy, sometimes miserable sobriety; until again, I relapsed. That relapse landed me in yet another treatment facility. This time, though, I did something different; I listened. I finally listened. I listened to the stories of my peers. I listened to the stories of my counselors and chaplains. I listened to myself tell the story of my life. I thought about what the next part of the story would be. I desperately wanted a new, 
different chapter and that is when my recovery truly began.

I know what worked for me and it was, and still is, stories. In treatment, a counselor said to me, "if you hang out with normal people too long, you start to think that you are one." That may be the most important lesson I learned. I must continue to listen to the stories of other alcoholics. I am not normal and never will be. The stories of other alcoholics helped me to get sober and helps me to stay sober. Telling my story aids in my sobriety. Dr. David Crespy is quoted by Gary Garrison in his book A More Perfect Ten stating "If a play doesn't cost you something to write, then maybe it's not really worth the effort." This is profoundly true when it comes to disclosing and examining aspects of one's life; which, unfortunately for many people, is considered best left unexamined and unsaid. Alcoholism still carries with it a certain stigma; however, I am willing to embrace that stigma if it helps just one more alcoholic achieve sobriety. My life has led me down a path where I am now able to share my story through a medium that has the potential to reach and assist countless people. It is my duty to do my best to make this happen. I am writing plays about alcoholism because giving testimony to the disease helps destigmatize alcoholism as well as recovery. I have stories to contribute and a platform on which to deliver them. They worked for me and they will work for others. It's what Bill W. and Dr. Bob did, so I shall do the same.

Through my years of active alcoholism, attempts at recovery and finally gaining a lasting, honest and true state of recovery, I have come to realize certain truths about alcoholism and recovery. Not all recovering alcoholics have the same perspective or notion of truth. Recovery is personal and different things work for different people. Therefore, prior to continuing, it is important to disclose my personal truth of how I view 
alcoholism and recovery. This truth informs my perspective and it would be an impossible task to remove my truth from my writing. The following are my aesthetic truths, not necessarily based on fact, but what I hold to be true:

1. Alcoholism is a disease. There is no cure. It can only be treated.

2. Alcoholism can be inherited. Children of alcoholics are more likely to become alcoholics than children of non-alcoholics.

3. Without admittance of a problem, an alcoholic cannot recover.

4. Recovery is an ongoing, never-ending process.

5. An active alcoholic and/or addict is not in control of his/her actions.

6. Listening to the stories of other alcoholics and sharing our own stories is an effective tool in recovery.

7. Much of the American public does not understand alcoholism.

8. There is not always a psychological deficiency that causes alcoholism.

9. Physical addiction to alcohol is incredibly powerful.

10. Without ridding the body of alcohol, the mind will never allow itself to begin recovery - detoxification MUST come first.

11. AA's twelve step program is not a program on how to achieve sobriety. Instead it is a program that teaches an alcoholic how to live a sober life.

12. Not all alcoholics need an AA program to get sober.

13. There is a difference between an alcoholic believing they cannot drink and an alcoholic that does not want to drink.

14. Relapse is nothing of which to be ashamed. 
15. For an alcoholic, recovery will be one of the most difficult things to achieve in their life.

16. It is possible for an alcoholic to recover and live a happy and fulfilling life.

17. Though each alcoholic has a unique story, we are all similar in some way.

18. Non-alcoholic family and friends of alcoholics who want an alcoholic to stop drinking should not change their own behavior to accommodate the alcoholic's recovery. It only makes the alcoholic feel ashamed all over again.

19. Alcoholism kills people.

20. Alcoholism is not the alcoholic's fault.

Though these personal beliefs about alcoholism and recovery are explored, addressed, illuminated and/or argued directly or indirectly throughout the dramatic works included in this project, they are more prevalent and recognizable in The Disappointments. Comparatively, The Recovery Project, because it is an ethnographic work, also touches on many of these beliefs; however, they are the beliefs of others and it was inherent that in creating the work, I remove myself and my beliefs from the process. Conversely, in Sliding into Home these beliefs are not transparently revealed in the drama; rather they are included in the development of the characters and their subsequent actions, which are based on their alcoholic and/or addictive character traits.

The Disappointments is highly autobiographical, both in story and ideals. The Disappointments uses plot, subject matter, and linearity as it follows an alcoholic throughout his recovery at a treatment facility. Many of the ideas and tools I personally learned in my own journey to recovery are presented to Second, the protagonist of The Disappointments, by his counselor, Patrick. One of Patrick's objectives is to teach 
Second and his other patients this set of beliefs, which, essentially are my beliefs. Second's education about alcoholism leads to his recovery.

In The Recovery Project many of my personal beliefs come through; however, this is not due to any prompting on my part, but manifests because of the similarities among recovering alcoholics. As alcoholics try to recover, especially if they utilize a twelve-step program like AA, it is only natural that a somewhat-aligned belief system is shared. For The Recovery Project, I only gave one prompt to each interviewee; "tell me what you were like; what happened, and what you are like now." They responded accordingly. Therefore, my beliefs may be recognized in the text, but they are entirely those of the recovering alcoholics interviewed.

Sliding into Home is shaped with a focus on plot and gets its drive from the actions of active alcoholics and addicts and those who love them. Therefore, it was essential that I somewhat stepped away from my beliefs about recovery and let the characters I built tell the story. Regarding this, I strongly believe the playwright cannot be taken out of the play and this is the case for Sliding into Home. Much of the action of the characters, especially those afflicted by addiction, such as JD, Cobb and Dale, is justified by the twenty guiding principles previously outlined. Though these principles are not on the surface, they simmer underneath, stoking the action of the play.

Alcoholism is a disease that is not going anywhere anytime soon. As Norman Denzin surmises in his seminal text on Alcoholism, The Alcoholic Society, the United States is a country that loves alcohol but does not like alcoholics. ${ }^{17}$ As advertising and

\footnotetext{
${ }^{17}$ Norman Denzin, The Alcoholic Society: Addiction and Recovery of the Self (New Brunswick, NJ, U.S.A.: Transaction, 1995), 2-4.
} 
marketing firms are paid millions to entice people to drink more, rehab facilities and twelve-step programs with little to no budgets do their best to help alcoholics to stop drinking. This dichotomy is apparent; yet it is largely left unchallenged in our society.

However, I am not here to argue the politics of alcohol in America. Instead, I recognize this vicious cycle and wrote plays that may help. 


\section{Chapter 2: Purpose, Literature Review and Methodology}

\section{Statement of Purpose}

As previously stated, it was my intention to utilize my personal experience, the experiences of others, inspiration from other playwrights, sociological studies on alcoholism and identity, different dramatic writing techniques and, perhaps most importantly, creativity, to generate dramatic work that addresses/explores and increases understanding of the subject of alcoholism and the experience of alcoholics. Questions guiding this project include: How can I create dramatic works that may contribute to the recovery from, and de-stigmatization of alcoholism? What different playwriting techniques can I use to make these plays the most effective? What past experiences of my own, if any, should I include in these works? What are the aspects of alcoholism and recovery that are necessary to cover? How do I make these plays engaging so they will have the most impact possible?

This series of plays is intended to entertain, to educate, and to act as an additional tool in the understanding and treatment of alcoholism. They are not meant to replace, criticize, or promote current methods of alcoholism treatment or various treatment programs. This dissertation is about creating new, substantive, and impactful works for the stage that will impact alcoholics, recovering alcoholics and the public in several ways: 1) By sharing narratives, as with AA, alcoholics will know that they are not alone.

2) By sharing my personal experiences, alcoholics can decrease their fear of treatment and the sober life style. 3) By witnessing the horror of an active alcoholic's life compared to the positivity of a sober life, an active alcoholic may be encouraged to consider the latter. 
For this purpose, I wrote three plays. Each play approached alcoholism from a different perspective utilizing a different style and form of playwriting. In addition, I wrote a scholarly introduction, which elaborates the intended purpose/goal of each play, the inspiration for each play, the perspective and lens through which each play is written, the theoretical approach, structural design, and how each play fits into the canon of dramatic literature. Though these plays are original works, they are not meant to be investigations or experiments in form, but rather a utilization of learned playwriting skills, theoretical approaches, and style choices specifically chosen to maximize the impact and strength of the storytelling.

Though one of these plays is specifically titled The Recovery Project, the three plays can be placed under the common moniker of The Recovery Project. This is because the three plays together work towards a common goal: understanding alcoholism. This goal is two-fold. Through the literature and/or performance, my intention is to provide various audiences with either an initial or further understanding of alcoholism for active alcoholics, alcoholics seeking recovery, recovering alcoholics, loved ones of alcoholics or the public-at-large. Additionally, and perhaps a bit selfishly, writing these plays allowed me to pursue a more complete understanding of the disease, which has immensely impacted the past twenty-five years of my life. Put simply, writing these plays helped, and continues to help, keep me sober.

Separately, each play was written for its own unique specific purpose. Sliding into Home offers an intimate portrait of a family wounded by unintended actions caused by drinking. More specifically, it directly addresses the effects a drunk driving accident can have on those involved. Though the play is set against the backdrop of an overbearing 
father and his relationships with his children and wife, the action of the play is put in motion by an accident caused by drunk driving. In the United States in 2016, 10,497 people died in drunk driving related automobile accidents. That is one death every fifty minutes. Additionally, 290,000 people were injured in drunk driving crashes. ${ }^{18}$ Though these statistics are troubling to say the least, they do not address the consequences these accidents have on the loved ones of those killed or injured; nor do they address the effects a drunk driver's actions and subsequent punishment has on his/her friends and family. These effects cannot be explained statistically because the mental and emotional repercussions a drunk driver's actions have on him or her, their loved ones, or their victims cannot be quantitatively gauged; however, this does not discount the pervasiveness and severity of the impact.

Personally, my own DWI arrests, which, by the grace of God, did not result in injuries, did result in my own mental anguish. It also resulted in a lot of stress on my family. ${ }^{19}$ When I went to prison/rehab, my mother and sister were tasked with trying to hold my life together while I was away for five months. I know the stress of this nearly put my mother "over the edge." With Sliding into Home, I deliberately wanted to show audiences the effect that drinking and driving has on the offender and his/her family. Perhaps after seeing the play, someone in the audience will decide not to drive after having some drinks and a life may be saved. If my play results in the safety of just one person, I will consider it worth it.

Additionally, Sliding into Home attempts to depict the effects of the "American dream" and how dissatisfaction with one's life can wreak havoc on his/her emotional

\footnotetext{
18 www.nhtsa.gov/risky-driving/drunk-driving (2017 Statistics are not yet available)

19 See, for example: americanaddictioncenters.org/alcoholism-treatment/family-marital-problems/
} 
state and cause not only him/her, but those he/she closely interacts with, to engage in behaviors he/she otherwise would not. ${ }^{20}$ Specifically, the play examines how a father's obsessive behavior affects his children. His obsession is not alcohol, rather it is his need to live vicariously through his three sons and their potential success as baseball players. Naturally, each son reacts differently to their father's obsession; one in defiance, and the other two with substance abuse issues that result in addictions. This gives the additional purpose for this story beyond the more straight-forward effects of DWIs, to illuminate for audiences a recognition of behavior, either of their own or of others, and to gain a more informed perspective on how the actions of one can affect another. ${ }^{21}$

The purpose of The Disappointments is to closely examine the treatment of alcoholism. Additionally, I want to aid those in recovery to more fully understand what they are going through and allow those considering recovery a glimpse into what they might expect. To achieve this lofty goal, I decided to utilize my own experience, specifically utilizing my last experience in a treatment facility, which occurred in November and December of 2015 at Valley Hope in Boonville, MO. Additionally, it also utilizes my experience with the prison/rehab I experienced at the Western Missouri Correctional Center (now the Western Reception, Diagnostic, and Correctional Center) from August to November of 2011. I possess an extensive daily journal of the latter experience.

Though this journal would seem an effective primary resource, it was utilized more to inform the characters in The Disappointments rather than the story or the aspects

\footnotetext{
20 Alcoholics Anonymous, 21.

21 See, for example: J.D. Jameison and William Stone, "Predicting DWI education success," Federal Probation 55, no. 1 (March 1991): 43-47. PsycINFO, EBSCOhost (accessed March 19, 2018).
} 
of recovery that are addressed. This is due to the nature of the journal, which does not focus on my recovery, but more on the day-to-day happenings and my extreme desire to go home. However, one aspect that does mirror my stay at Valley Hope was the attitude toward recovery which the protagonist in The Disappointments possesses as compared to the other alcoholics/addicts in the facility. Second, the protagonist of the play, desires recovery. In my experience, however, I have found that most people in rehabilitation do not really want to recover. That is one of the truths I believe much of the public and families and friends of alcoholics are misled to presume; that everyone in rehab wants to get better. Some, if not most, simply do not want recovery. I want to illuminate that fact. $^{22}$

Alcohol and addiction treatment facilities are tragic yet funny. With The Disappointments, I want to demystify any false perceptions people have about treatment. During my stay at Valley Hope, which lasted twenty-four days, I heard many anecdotes and life-stories that were painful and heart-rending but were also moving and inspirational. I watched as patients came in, stayed a few days, then left because they could not stand being sober. While there, a patient everyone really liked and expected to thrive on the outside, died of an overdose soon after leaving, which left those still in treatment reeling. Several patients were kicked out for using or sneaking in booze. Two patients were kicked out because they got drunk and were caught having sex in the woods adjacent to the facility.

At Valley Hope, when a patient finished his/her treatment, he/she receives a coffee mug, which they get to decorate and then hang on the wall. There are hundreds of

\footnotetext{
${ }^{22}$ See, for example: J.D. Jameison and William Stone. "Predicting DWI education success." Federal
} Probation 55, no. 1 (March 1991): 43-47. PsycINFO, EBSCOhost (accessed March 19, 2018). 
cups lining the walls; this proves empowering to those who feel like they are not going to make it through treatment. Strikingly, amongst the array of hanging cups, there is a section containing a shocking number of cups belonging to previous patients that have died due to their alcoholism or addiction.

Converse to the tragedy is the comedy that permeates the treatment facility. Addicts and alcoholics, for the most part, are very bright, funny people. Though their stories may be tragic, their sense of humor is evident. It is awe-inspiring to witness someone come out of detoxification and regain his/her sense of self as his/her brain and body mend. This metamorphosis releases a joy and humor in people unlike anything I have ever seen. I distinctly remember a night during a game of spades at Valley Hope in which the four of us at the table laughed hysterically for hours. There is a selfdeprecating, sarcastic humor among a treatment cohort that makes treatment not only bearable, but in fact, fun. However, I would be negligent if I did not state there are exceptions to this. There exist patients who enter and just want to leave. They are mad, unpleasant, sad, depressed, and/or bound by trauma and they never snap out of it. It is a challenge not to allow their darkness to affect one's own desire to enjoy treatment and/or focus on recovery.

With The Disappointments, I wanted to show all this. To do this, and this will be explored more in the methodology section, I utilized realism and linear techniques. It is reality, or the truth about treatment, that I want audiences and/or readers to recognize and digest. Intentionally, I did not want audiences to be confused by a theatricality or a style that would result in any confusion and/or questions about the reality of treatment. The most recent play produced on alcoholism, addiction and treatment is Duncan 
MacMillan's People, Places and Things (2015). MacMillan's play “presents a theatrical interpretation of the treatment of alcoholism and addiction." 23 This results in a play that does not allow a glimpse into the realities of treatment but is more an existential journey about addiction and theatre. This is contrary to my goal, which, as previously stated, is to allow audiences to see the reality of treatment. However, the popularity of this play reveals there is a place in American Theatre for plays about alcoholism and addiction. ${ }^{24}$

The Disappointments aesthetics utilizes Aristotelian techniques, traditional linear plot structure, engaging characters, and the current trend of ninety-minute, nointermission and continuous (no pauses for scene changes) scenes to tell an engaging story that educates people on the realities of alcoholism treatment and recovery. Additionally, I set out to dramatize my own experience in treatment. Telling an autobiographically-inspired story lends credence to the realism of the play.

The Recovery Project functions as a dynamic ethnographic performance text that allows for adaptations, which specifically targets people trying to recover from alcoholism. The dialogue of the play was created by using the actual words of people in recovery. Through several interviews with recovering alcoholics and addicts, the script shows people who may be trying to recover what it is like to be an alcoholic in recovery. By using words of actual people who have found recovery, the desired effect on audiences (those trying to get sober) is that they get to see and hear the possibilities of a life without substance abuse. The AA supplementary book Twelve Steps and Twelve Traditions states in its exploration of the third step of the AA program that "there is only

\footnotetext{
23 Michelle Paul, "People, Places and Things: Addiction, Identity and Performance" (Journal of Contemporary Drama in English, (Nov. 2016, Vol 4, Issue 2), 267 -285.

24 In 2017, People, Places and Things transferred from the London National Theater to St. Ann's Warehouse in New York City.
} 
one key, and it is called willingness." 25 The end goal of The Recovery Project is to help alcoholics become "willing" to recover. Then, perhaps, they will find recovery.

The play functions as a one-person show to be performed in recovery houses, treatment centers, possibly jails and/or prisons and for the general public. The play has minimal scenery (only one chair is needed); and, perhaps some minimal costumes are required to delineate among the characters (much of this would be figured out in the rehearsal room). I intend to be the first actor to perform the text, but I want to make it available to any production team who might be interested.

The Recovery Project is inspired by the work of Anna Deveare Smith. Smith's work in ethnographic performance is legendary. Her plays Fire in the Mirror and Twilight: Los Angeles, 1992 are credited for pushing ethnographic solo performance into the psyche of American theatre; making it relevant and more popular, enticing producers to risk the style. In a review of Notes from the Field, Smith's 2016 work about the intersection of two American institutions, public school and prison, New York Times critic Ben Brantley states, "she creates dialogue out of monologues among souls who, in real life, might never have occasion to speak to one another."26 My goal here is similar, I put a variety of characters on stage and have them speak to each other, not literally, but voices in one room speaking about the same subject: recovery. The hope is that these voices inspire willingness and, in turn, hope, which then leads to recovery.

\footnotetext{
25 For more on "willingness" see Twelve Steps and Twelve Traditions, 34-41.

26 Ben Brantley, "Review: Anna Deveare Smith's 'Notes From the Field' Delivers Voices of Despair and Hope," The New York Times, Nov. 2, 2016.
} 


\section{Significance and Literature Review}

It is difficult to predict the potential significance of creative work. The three plays were written with the end goal of being produced; however, it would be irresponsible of me to guarantee future productions. Therefore, the significance lies in the strength of each play as literature and where that literature fits into the dramatic canon. The significance, originality, and effectiveness of the literature comes from my perspective as a playwright and a recovering alcoholic. Additionally, knowledge gained from extensive study, research and conversations with other alcoholics boosts each play's significance and authenticity.

The dramatic canon consists of various works that address alcoholism and its personal and social effects. Some works use alcoholism as merely a narrative device in an effort to give certain characters, or scenes, a foil from which a drama can unfold. As I discuss in this section, the canon consists of meaningful works that do address the depth and complexities of this disease. My work, however, deals with the underrepresented narratives of recovery. As I argue, recovery is intertwined with the process of storytelling. My contribution to the dramatic canon regards recovery as the master narrative from which all action derives. Thus, The Recovery Project fills a gap within the dramatic canon. It is a continuation on a theme. Where others have focused on the active alcoholic, I focus on recovery.

The following provides analysis that compares The Recovery Project trilogy to other playwrights' work that addresses or utilizes alcoholism and/or recovery as a subject. These include works from playwrights such as Eugene O'Neill, William Inge, Edward Albee, Duncan Macmillan, Gary Lennon, and Tracy Letts. Others, of course, 
exist, but the work of these particular authors was, and remains, influential on my own creative work. Additionally, a comparison will be made between The Recovery Project and the work of Anna Deveare Smith.

The American stage is no stranger to plays that advocate for sobriety and/or explore alcoholism. In 1844, as part of the temperance movement, The Drunkard or The Fallen Saved, a play by William Henry Smith, premiered in Boston and quickly gained popularity. In 1850, it was given a 100-night run by P.T. Barnum in lower Manhattan and soon gained national popularity and productions in cities all over the country. "Barnum's production of The Drunkard heralded the entry of temperance narratives into mainstream theatre and immediately became the standard against which all other temperance dramas were measured." ${ }^{27}$ The American Temperance Society, the engine powering the temperance movement attributed much of its rising popularity to The Drunkard and other pro-temperance plays like T. S. Arthur's Ten Nights in a Bar-room. The Drunkard is a melodrama, which was the most popular theatre style of the $19^{\text {th }}$ century, exemplified by the enormous popularity of the $19^{\text {th }}$ century mega-hit, Uncle Tom's Cabin. The Drunkard and the subsequent other temperance plays had their desired effect. The plays delivered the message of abstinence in an entertaining way, thus engaging the audience. This allowed for the temperance ideals to fully penetrate the individual and collective consciousness.

Temperance plays were integral in the rise of the $19^{\text {th }}$ century temperance movement. The temperance movement culminated in a major push in the 1910s, which resulted in Congress passing the $18^{\text {th }}$ Amendment to the United States Constitution. The

\footnotetext{
27 John W. Frick, Theatre, Culture and Temperance Reform in Nineteenth-Century America (Cambridge
} University Press, 2008), 113. 
new Amendment passed in 1918, prohibited the sale and possession of alcohol throughout the nation. Although prohibition proved unsuccessful when the government was unable to take alcohol completely out of the hands of American citizens, the problem of alcoholism had, nonetheless, entered the zeitgeist of the American psyche and was never to exit.

Eugene O'Neill used realism's popularity in the early/mid-20th century to explore his own anguish brought on by the alcoholism and addiction that plagued his family. With his semi-autobiographical masterpiece, Long Day’s Journey into Night, O’Neill took a giant leap forward into the staged reality of alcoholism by providing an honest, horrifying portrayal of a day in the life of a family tormented by their liquid demons. O'Neill wrote the play between 1941 and 1942, but, at his instruction, the play was not to be published or produced until twenty-five years after his death. However, after O'Neill died, his wife turned the manuscript over to be published and performed in 1956 . The agonizingly honest portrayal of addiction and alcoholism combined with O'Neill's skill as a playwright struck a chord with theatre audiences and posthumously won O'Neill his fourth Pulitzer Prize in 1957. The rise of realism and popularity made the exploration of alcoholism and addiction on stage a viable option for producers to consider allowing numerous plays about alcoholism and addiction to be produced since Long Day's premiere and publication. Though an argument may be made that at the center of Long Day's is the morphine addiction of wife and mother Mary "there is, of course, sufficient evidence in the play that the Tyrone men are alcoholics." 28 I can personally attest to the

28 Steven F. Bloom, “Empty Bottles, Empty Dreams: O’Neill's Use of Drinking and Alcoholism in Long Day's Journey Into Night." Critical Essays on Eugene O'Neill. Editor: James Martine (G.K. Hall: Boston, MA, 1984), 167. 
depiction of gradual, into complete inebriation of the men over the course of the day.

This is a routine that is characteristic of an active alcoholic.

Eugene O’Neill was an alcoholic. He battled his alcoholism until the age of thirtynine after which point he remained abstinent. O’Neill was a "periodic drunk" who would sober up long enough to write his plays then return to "research-intensive benders." 29 In 1927, O'Neill sobered up prior to the advent of AA and without participation in a treatment program; however, this does not discount his insight into the workings of the mind of the alcoholic. In an article written for The Eugene O'Neill Newsletter by Gloria Dibble Pond, she states:

Before the principles of Alcoholics Anonymous (AA) were fully articulated, Eugene O'Neill dramatized remarkably two of the central characteristics that make alcoholism a family disease: denial and enabling or acquiescence in the development of the disease. In Long Day's Journey Into Night, O'Neill created a family whose members reinforce each other's addictions and who use morphine, whoring, and greed as opiates analogous to alcohol. ${ }^{30}$

Aside from its importance to the dramatic canon, Eugene O'Neill's play still has a profound impact on me every time I read it. As a recovering alcoholic, and someone who has the personal experience of having a drug-addicted parent, I recognize O'Neill's ability to tap into the harsh reality of alcoholism and addiction, which assures me I am not alone in my experience. Knowing that he was willing to write this and was willing to expose his personal experience (even posthumously) is one of the compelling reasons I chose to embark on this project.

In 1939, prior to Long Day's, O’Neill wrote another work that is saturated with

29 Doris Alexander. Eugene O'Neill's Last Plays: Separating Art from Autobiography (Athens: University of Georgia Press, 2005), 88.

${ }^{30}$ Gloria Dibble Pond., “A Family Disease,” The Eugene O'Neill Newsletter, Vol. IX No. 1, Spring, 1985. 
alcohol and alcoholics. The Iceman Cometh is about several alcoholics who hang out in a saloon in Greenwich Village in 1912. "It would be difficult to imagine a work of literature more thoroughly steeped in alcohol." ${ }^{31}$ All the action takes place in the saloon throughout the course of one day as the men in the play drink (or don't drink) and talk about their unrealized hopes and dreams. Hickey, one of the central characters of the play, "confuses his friends when he shows up early instead of drunk." 32 This play is another example of O'Neill's uncanny sense of alcoholism's effects on the psyche of an individual.

The only play written for this project that loosely resembles an O'Neill work is Sliding into Home, as it addresses how alcoholism and addiction can be detrimental to the health of the American family. In The Disappointments, we see similarities to the unrealized dreams of the characters in The Iceman Cometh, which result in the constant need of an alcoholic to escape the misery brought on by the feeling of being a disappointment to oneself or others. However, The Disappointments is a play that possesses a theme of hope and recovery while The Iceman Cometh is tragic, and its theme is that men must be driven by "pipe dreams" or else they fall apart. This directly contradicts AA teachings, which proposes that people need to appreciate what they already have.

Premiering first at the Westport County Playhouse, then moving to Broadway's Booth Theatre on February 15, 1950, William Inge's Come Back, Little Sheba, follows the story of Doc, a recovering alcoholic whose relationship with a young woman leads him to relapse. William Inge was an alcoholic who had turned to the then nascent

31 T.B. Gilmore, "The Iceman Cometh and the anatomy of alcoholism," Comparative Drama 18(4), 335.

${ }^{32}$ Ibid. 
Alcoholics Anonymous to aid in his recovery. From the opening pages of the play, the early philosophy and program of AA is explored in the play's text. In the opening scene, Doc and his wife Lola discuss Doc's upcoming year anniversary of his sobriety. Lola asks him if he going to a meeting that night and Doc states that he is not, that he is going on a Twelfth step call. He says to Lola, "I showed you that list of the twelve steps the Alcoholics Anonymous have to follow. This is the final one. After you learn to stay dry yourself, you go out and help other guys that need it." 33 In this one line of dialogue, which was performed before thousands of audience members over the course of the Broadway run, a window into AA was opened. One could surmise, as well, that a few alcoholics in the audience heard this; and, perhaps after witnessing the performance found their way to their first AA meeting.

When the theatrical style of realism was introduced to theatre and embraced by mass audiences in the first half of the $20^{\text {th }}$ century, playwrights began using realism's societal mirror effect to present alcoholism on stage. Playwrights showed audiences the many negative effects the disease has on alcoholics and the people that interact with the alcoholic and are also affected by the disease. Some of America's most lauded plays have explored alcoholism. Pulitzer Prize-winning plays that continue to influence my own understanding of alcoholism and how it works in dramatic writing include Long Day's Journey into Night by Eugene O’Neill (1957), Cat on a Hot Tin Roof by Tennessee Williams (1955), How I Learned to Drive by Paula Vogel (1998), August: Osage County by Tracy Letts (2008), Water by the Spoonful by Quiara Alegria Hudes (2012), and Between Riverside and Crazy by Stephen Adley Guirgis (2015). Other plays that

33 William Inge, Come Back, Little Sheba, (New York: Samuel French, 1950), 11. 
influence my writing in the context of alcohol or alcoholism include Who's Afraid of Virginia Woolf? by Edward Albee (1962), Fifth of July by Lanford Wilson (1978) and The Motherfucker with the Hat by Stephen Adley Guirgis (2011).

Of the more contemporary works, those most influential plays on this project are August: Osage County by Tracy Letts, Blackout by Gary Lennon, and People, Places and Things by Duncan Macmillan. August: Osage County like Long Day's explores the effects addiction has on family. It was an additional resource in the writing of Sliding into Home. Blackout is a fictional account of members of AA telling their stories over the course of an AA meeting. It is the dramatic work that most closely resembles the content of The Recovery Project. Although I appreciate this play; it epitomizes the type of play I did not want to write - an overly-dramatic sob fest peppered with unlikeable characters. People, Places and Things, being the most recent work about alcoholism and recovery to garner several major productions, has been important to this process as it has also taught me that I did not want over to over-theatricalize The Disappointments.

Another pillar in the foundation of this trilogy is my desire to write plays that are about alcoholism and recovery. The comparison of the amount of plays which include active alcoholism and addiction to plays about recovery is really no comparison at all. As represented in my literature review, it is noteworthy to recognize most of the plays influencing the writing of this trilogy are plays about active alcoholics and addicts - that is simply because more of these plays exist. We live in a world where there are way more alcoholics than people recovering from alcoholism. Therefore, if theatre is a reflection of society, then it makes sense that this is the case.

Perhaps society is ready for more plays about recovery. The production, 
publication and strong reviews of MacMillan's People, Places and Things is a good starting point. However, on television, there are two popular programs on major networks that deal directly with recovery. The first show is a sit-com titled Mom which showcases strong comediennes in Allison Janney and Anna Faris. The show's creator/showrunner is Chuck Lorre, the hottest sitcom producer in the business right now who also happens to be a recovering alcoholic. Though I have trouble buying into the sitcom genre - the show has garnered multiple positive reviews - its popularity has allowed it to remain on the air since 2013.

The other show is the immensely popular This is Us, an hour-long drama created by Dan Fogelman (no history of alcoholism that I can find). At the heart of this nonlinear generational family exploration is a loving father of three children. Told through flashbacks, viewers discover that the father is an alcoholic who struggled to get sober and ultimately joined AA, so he would not lose his family. It is apparent the show's writers took great care in telling this story. It is a well-done example of the lesser told narrative of alcoholic recovery. Perhaps if these television shows can be successful, there is room on the stage for more plays about recovery.

Anna Deveare Smith's plays Fires in the Mirror and Twilight: Los Angeles, 1992 as well as her book Talk to Me were highly influential on the creation of The Recovery Project. In Talk to Me, Smith discusses at length the importance of listening to people. It is one of the reasons why I chose to give the interviewees for The Recovery Project an open-ended question and then just let them speak while I listened. Though The Recovery Project is very similar in structure and method to the ethnographic performance texts of Fires in the Mirror and Twilight: Los Angeles, 1992, there is a key difference. When she 
is conducting interviews, Smith plans to play the actual characters she interviews and gets their permission. I did not have that privilege due to need for guaranteed anonymity for the interviewees. This highly influenced the text of The Recovery Project, as it became more about content than character, which is somewhat contrary to what Smith does.

Thomas Michael Campbell's 2013 dissertation Alcoholism on the American Stage: De-Stigmatizing Socially Constructed Depictions of the Alcoholic through Performance is the most recent dissertation concerning the subject of alcoholism on the American Stage. Campbell's dissertation “examines plays that perpetuate stigmas as well as plays that seek to subvert stigmas and stereotypical depictions as a means of creating avenues for discourse." ${ }^{34}$ My dissertation is very much in conversation with his. His dissertation does an excellent job of defining terms and explaining alcoholism and how it works on the human body and mind. He explains the stigma associated with alcoholism and explains how this stigma has been propagated due to the depiction of alcoholism in specific plays. He counters this by also discussing plays that represent alcoholism in ways that help to de-stigmatize alcoholic. Finally, he presents an argument for how theatre could further this de-stigmatization. His appendix includes a dramatic work that he authored. It follows a character in recovery and how the stigma of being an alcoholic affects his life. This play, Descarte a la Mode, is "designed to illustrate the negotiations with identity found with new-found sobriety" and Campbell's "hope is that [the play] challenges all participants to see the complications involved when a person must face his/her damaging use of alcohol."." ${ }^{35}$ I cannot understate the impact Campbell's work had

\footnotetext{
${ }^{34}$ Thomas Campbell, Ph.D. Alcoholism and the American Stage: De-Stigmatizing Socially Constructed Depictions of the Alcoholic through Performance, (Dissertation, Southern Illinois University - Carbondale, 2013.) http://opensiuc.lib.siu.edu/cgi/viewcontent.cgi?article=1668\&context=dissertations

35 Thomas Campbell, 180 -181.
} 
on my own and I feel my dissertation is really a continuation of his insightful work. The main difference in our two dissertations is that my dissertation focuses on the creation of dramatic work and Campbell's focuses on work which has already been created. Though he presents his own play as part of his dissertation, it is supplementary to his thesis.

Norman Denzin's seminal 1995 book, The Alcoholic Society: Addiction and Recovery of the Self has been significant in my understanding of the science and scholarship that exists about alcoholism and recovery. His insight and explanation of theoretical frameworks associated with alcoholism are comprehensive and enlightening. Infusing dramatic work with scholarship is not easily done, but Denzin's exploration of the linear narrative of the alcoholic's life from first drinks to recovery were extremely helpful in creating characters and their motivations. Additionally, and perhaps most importantly, this book allowed me to understand myself a little better.

Wasted: Performing Addiction in America (2015) by Heath Diehl explores how addiction and alcoholism is portrayed in American pop culture and how this exploration is inspired by, and concurrently, propagates the social construct of, viewing the alcoholic or addict as an “other.” Additionally, as in Denzin's work, theories of identity and their influence on the alcoholic are described. Since I am writing plays that will hopefully find their way into mainstream culture, this book made me aware of the negative effects pop culture can have on society's view of the alcoholic/addict when not treated with care. The book also addresses the idea of waste and the metaphor of waste as it pertains to the alcoholic/addict. This view reinforced my belief that resentment due to unrealized dreams is a frequent catalyst for an alcoholic's disease progression.

Diehl's scholarship is firmly placed in the humanities, specifically performance 
studies. Diehl provides additional justification for my project as he argues there is a lack

of alcoholism/addiction scholarship as it pertains to the arts and humanities. He states:

To date, the bulk of extant scholarship on the subject of addiction hails from the natural and social and sciences. Within the arts and humanities, significantly less attention has been devoted to the subject of addiction, and those scholars have pursued this subject typically have identified as 'historians' and their intellectual work has tended to concentrate on a select few concerns . . . historical expressions of addiction ... and socio-historical forces that have contributed to the rise and/or decline in popularity of a specific substance. ${ }^{36}$

This categorical lack of artistic addiction scholarship makes the addition of The Recovery Project, The Disappointments and Sliding into Home relevant.

The Recovering: Intoxication and its Aftermath (2018) by Leslie Jamison is an autobiographical reflection on Jamison's life as an alcoholic and subsequent recovering alcoholic. This book became important late in the process of writing this dissertation, but it has profoundly affected me. Jamison is a scholar who earned a Ph.D. in English from Yale. She found recovery before she entered her Ph.D. and when it came time to write her dissertation, she wanted to do something meaningful — at least meaningful to her. In the book she discusses her first meeting about her dissertation and the professor pressing her to find a topic. She ends this discussion with something that has stuck with me since I read it. She states, "I think addiction is the opposite of variation." She goes on to explain this: "Addiction is just the same fucking thing over and over again. Thinking of addiction in terms of generative variation is the luxury of someone who hasn't spent years telling the same lies to liquor store clerks." 37 In other words, the story never changes, until it does.

\footnotetext{
36 Heath Diehl, Wasted: Performing Addiction in America (Farnham: Ashgate, 2016), xii.

37 Leslie Jamison, 424-425.
} 


\section{Methodology}

Though each of the plays written for this project are different in many ways, they do act as a trilogy; the three plays are all in conversation with each other. Ultimately, I determined that the plays needed to stand alone; but, if read in order they mirror the story of an alcoholic who finds recovery. The trilogy has a beginning, middle and end like an alcoholic telling the story of what he/she was like, what happened and what he/she is like now. Therefore, the trilogy begins with a story, Sliding into Home, in which no one identifies as an alcoholic, recovery is not sought, nor even discussed, and this leads to tragedy. The middle play, The Disappointments, finds its characters seeking and discovering recovery. There exists a moment about halfway through this play where the protagonist, Second, admits that he is an alcoholic and his recovery truly begins. This moment could be considered as the middle of the trilogy, an identity shift which ultimately, at the end of the play, leads to hope and recovery for Second. The end play, The Recovery Project is comprised of stories from people who readily identify as alcoholics, have found recovery, and are living sober lives.

Identity is the most important aspect of an alcoholic finding recovery. It is why the first step is dependent on the declaration of a new "alcoholic" identity. An alcoholic cannot move forward until they "admit [they] are powerless over alcohol; and [their] lives have become unmanageable." It is also why, in AA, we constantly state we are alcoholics. An identity shift is different from an alcoholic going to his first meeting, visiting a doctor or seeing a therapist, though within any one of these an identity shift may occur. An identity shift can be characterized as a point in a person's life where 
he/she self-identifies in a new way that had otherwise remained unacknowledged. With alcoholism, however, this shift only occurs when an alcoholic honestly admits he/she has a problem. The alcoholic is the only one who knows whether he/she is being honest or not, though this honesty can manifest itself in the actions of an alcoholic. Put simply, an alcoholic can just say he/she is an alcoholic, but that is just a word. An alcoholic who honestly admits he/she is an alcoholic and take steps toward recovery experiences an identity shift. Identity theories in the social sciences are numerous and each potential illuminating as framework for this trilogy. However, relational identity theory provides the most meaningful method in which to frame this trilogy.

Within his article, Alcoholism and Identity; How an Alternative Framing of Identity can facilitate Alcoholics Anonymous Research, Lance Brendan Young describes relational identity theory. "Relational identity theories, in their purest form, state that identity is nonexistent absent interaction with others. People understand who they are only when they understand how they differ from other people and jointly ascribe significance to those differences." ${ }^{38}$ Relational identity theory builds upon both personal identity theory and social identity theory. Personal identity theory posits that identity is: conceptualized by personality, characterized by personality traits, determined by nature, located in the individual, and individually determined by what the individual chooses to disclose. Social identity theory asserts that identity is: conceptualized as a social role, characterized by cultural expectations, personally determined, but limited to context and develops over a lifespan. Relational identity theory advances that identity is conceptualized through interaction, characterized by meaning this is negotiated

\footnotetext{
38 Brendan Lance Young, "Alcoholism and Identity: How an Alternative Framing Of Identity Can Facilitate Alcoholics Anonymous Research," (Addiction Research \& Theory, 19.3, 2011), 213.
} 
interpersonally, determined by past, present, and by the anticipated responses of others. ${ }^{39}$ In respect to alcoholism, personal identity theory sees alcoholism as an "inherited vulnerability or trait" that is best treated by "purposeful rearrangement of motives." Social identity views alcoholism as an "adapted response to societal stressors" treated by “control of cognition, coping behaviors, and consumption," whereas relational identity theory regards alcoholism as a "relational breakdown:" an alcoholic's relationship with alcohol transformed into one of dysfunction wherein treatment occurs with rejection of the relationship with alcohol and "rearrangement of relationships." 40 Put in the simplest of terms, our identity is shaped by our relationships with everything.

I gravitated toward relational identity theory for the following reasons: 1) my relationship with alcohol, though I always drank somewhat alcoholically, evolved towards the end of my drinking days into utter dysfunction; 2) it is my interaction, or relationships, with other recovering alcoholics that helped me to achieve sobriety and retain sobriety; 3) one of the most important aspects of sobriety is knowing one's limitations and how those limitations relate to the world in which the alcoholic exists and moves; 4) abstinence is not recovery, though, of course, there exists a relationship between the two; 5) and perhaps most importantly, recovery from alcoholism cannot occur, I contend, unless the relationship with alcohol is repudiated and the building of new, substantial, productive and nurturing relationships occur.

Dynamic relationships, interesting relationships, loving relationships, volatile relationships - these are just a few of the types of relationships one might find in a work of dramatic literature. This does not just include relationships between or among human

\footnotetext{
39 Ibid, 215.

${ }^{40}$ Lance B. Young, 215.
} 
beings; but, rather it is an ecology of relationships. People have relationships with their home, their job, their dog, their phone, their education, music, movies, food and alcohol. The way in which a character relates to people, places and things is what determines their identity. People, places and things are also what one needs to change their relationship with while in recovery. Acknowledging that these different elements—character, people, places and things, and recovery are all in dialogue allowed me, a theatre scholar and playwright, to wrap my head around a social science theory, which could be implemented as a theoretical framework for this project.

Relational identity theory manifests itself throughout the trilogy. Overall, and perhaps, most importantly is the relationship characters have with alcohol and/or drugs and the evolution of this relationship. In Sliding into Home, the Stewart family is surrounded by the fog of the dysfunctional relationship members of the family have with drugs and alcohol. This relationship does not change, alcohol is not repudiated, relationships build and are broken by what alcohol has done to the family. The Disappointments shows the impact of repudiation (or abstinence) combined with new relationships and the positive result it can have on an alcoholic. However, its counterpart is also presented in that some characters devolve as they re-embrace their relationship with their addiction. This theory is perhaps best manifested by those involved in The Recovery Project. As the stories in the play unfold, it is apparent the relationship the participants maintain with Alcoholics Anonymous or Narcotics Anonymous in addition to the shift in their identity have ultimately resulted in their ability to stay sober.

Identity theory as a social science is usually used to predict behavior. However, in alcoholics or addicts, this is a skeptical endeavor at best. Mr. Young's article, 
"Alcoholism and Identity: How an Alternative Framing of Identity can Facilitate Alcoholics Anonymous Research," which, as the title suggests, attempts to aid in the ability to elucidate what treatments work and why, and is grounded in well-thought-out research and ideas, is still only scratching the surface. Alcoholics and addicts are unpredictable - this is because the disease is relentless. It is "cunning, baffling and powerful" $^{\text {"11 }}$ thus making it difficult for scientists to derive concrete conclusions about successful treatments. There is a fluidity to recovery; on any given day, an alcoholic's recovery can be strong and then the next day he/she is intoxicated again. It happens all the time - much to the chagrin of scientists everywhere. However, as a playwright, relational identity theory allows me to create a model to recognize the relational issues of alcoholism and recovery; while these relationships may not be wholly predictive, I am able to better understand these relationships and write about them truthfully.

Recovery can and does happen for some alcoholics. In forming the overall arc of this trilogy, I kept coming back to recovery. This is because it is the recovery that matters, not the alcoholism. Alcoholism is physically, mentally and socially destructive. Recovery is physically, mentally and socially productive. This project is meant to act as a productive entity, not a destructive one. However, a recovery needs a disease. Cancer does not get treated until someone has it; same with alcoholism. Most plays about alcoholism are just that; about alcoholism. They focus on the disease. I, however, focus on recovery from the disease, because I intend for my plays to be efficacious - to help alcoholics and the people who must live with them, support them, and love them, to understand the nature and possibility of recovery, rather than dwell on the ravages of the

\footnotetext{
${ }^{41}$ Alcoholics Anonymous, 58-59.
} 
disease.

In Thomas Campbell's dissertation, he contends that there are three stereotypes in theatre representing the alcoholic. These alliterative terms are useful: "the Loveable Lush," "the Despondent Drunk," and "the Violent Villain." ${ }^{2}$ Additionally, he argues that representations of the alcoholic in dramatic literature have evolved into a more truthful depiction in the past decades. However, playwrights have never been able to completely shake the alcoholic stereotypes for one main reason; they usually depict the alcoholic in active alcoholism. The plays written for this project are not completely free of stereotype, and I would never claim them to be; however, the focus on recovery and not the alcoholism (or addiction at times) allows for the plays to be grounded in a more truthful representation of alcoholism and the alcoholic.

Recovery is based in honesty and alcoholism is not. This assertion guides the impetus of utilizing recovery, and not active alcoholism, as an integral component in the crafting of these plays. In reflecting on my own recovery, the stories of others, and what I have learned from AA and working with a sponsor, I came to realize that my alcoholic life was a lie. During active alcoholism, an alcoholic is not their true self - I certainly was not. In simplified terms, an inebriated person acts differently than he/she would if he/she were in recovery; the alcoholic makes choices he/she otherwise would not, does things he/she otherwise would not and says things he/she otherwise would not. Therefore, the alcoholic is not living his/her truth, but living a life controlled by alcohol.

The recovering alcoholic is forced to face truth. Not only must they accept they have a problem and shift his/her identity; he/she must also learn to live life a without

\footnotetext{
42 Thomas Campbell, 42.
} 
alcohol. In a story from Alcoholics Anonymous, the storyteller states “. . . unless I accept life completely on life's terms, I cannot be happy." ${ }^{33}$ This means the recovering alcohol is who he/she is; the recovering alcoholic lives the life given to him/her, makes choices, does things and says things without the falsity alcohol possesses over him/her. Essentially, the recovering alcoholic becomes his/her true self again.

So, how does this idea of recovery-based dramatic writing differ from plays written with the focus on active alcoholism? More specifically, how does its separate the plays I wrote from others? It means that characters were built by first concentrating on what they were like before they became alcoholics. I never looked at a character as the "alcoholic" or "addict" character in the play. They are people dealing with the disease of alcoholism or addiction. They were who they were prior to the disease afflicting them; they encounter the disease and then, if they recover; they become themselves again, perhaps altered, but living their life again. This may seem counter to the identity-shift argument insofar as the alcoholic becomes a recovering alcoholic, but it is not. An alcoholic's transition into recovery means a transition back to truth. The alcoholic regains agency over their life; rather than maintaining the disenfranchised position in which active alcoholism cast them. These plays are a search for the truth; therefore, they are a search for recovery.

It is a deliberate choice, inspired by this focus on recovery, that these plays do not depict "war stories." "War stories" are the stories recovering alcoholics share about their time in active alcoholism. They differ from a recovering alcoholic recalling certain moments in their active alcoholism, which they feel shapes their history. "War stories"

43 Alcoholics Anonymous, 417. 
are usually crazy, full of conflict, funny, and entertaining anecdotes. These stories do have their place in recovery because they are a way we, in recovery, relate to each other; however, these stories tend to glamourize alcoholism and that is averse to the purpose of these plays. To that end, I had to be deliberate in my execution of writing these plays to not make them "war stories" or include "war stories." I found that if I focused on recovery the notion of "war stories" being an aspect of the plays was easily alleviated.

The use of relational identity theory and the focusing on recovery greatly informed the dramatic works included in this project. As a playwright, it can be challenging to keep a constant theoretical framework in mind while writing creatively. This trilogy of plays is a result of the attempt to be mindful of this methodological framework. 


\section{Chapter 3: Sliding into Home}

\section{Introduction}

What would it be like to kill someone unintentionally? I have thought about his question often over the past several years. I received my first DWI in 1995. I was pulled over for having a tail light out. I was young and dumb and deserved it. In 2007, I received my second DWI; I was pulled over for having a license plate light out (I did not even know there was such a thing) and was barely over the legal limit. I did not feel like I deserved this DWI and fought in the courts to no avail. However, my third and final one, I was falling asleep at the wheel and people driving behind me called the cops because they thought I was dangerous. I was dangerous. I was wielding a deadly weapon without any control over that weapon, whatsoever. When I finally came to understand this, it scared the hell out of me.

What happened was (and this is no excuse, just an explanation) my doctor had given me a prescription for Ativan to help me detoxify from alcohol. I went to see him in the morning because I really wanted to stop drinking. However, I could not get past the physical grip the alcohol held over my body and mind. Subsequently, the doctor gave me pills to help me sleep and curtail the shakes. When I arrived home from the pharmacy, I took two pills and fell asleep. All I remember of what happened next is a flash of sirens in my rearview mirror and then I woke up in a jail cell, having no idea what had occurred. Apparently, at some point after falling asleep, I awoke and decided to drive somewhere. I assume I was probably going to get more booze but cannot be sure. That morning, June $3^{\text {rd }}, 2011$, I left my house and did not return home until November $2^{\text {nd }}$, over five months 
later.

For the first couple months of being locked up, I was consumed with selfloathing. Then, in the treatment center at the Western Missouri Correctional Center, my counselor asked me this question: "What if you would have hurt or even killed someone?" This question hit me like a thunderbolt. At first, I felt ashamed that I had not even thought of that scenario. Soon, though, the shame wore off and I was filled with gratitude that my actions, of which I was not in control, did not result in the causing of pain to another. To this day, I feel blessed someone else did not have to get hurt for me to find my recovery.

Stories like mine abound, only many of them end in tragedy. Nicole LaFreniere, at the age of twenty killed three of her own friends while driving drunk. ${ }^{44}$ Eighteen-yearold Brandy Graff killed two sisters in 2005 after drinking all day at the beach and getting behind the wheel. ${ }^{45}$ One need only Google "tragic drunk driving stories" to find an abundance of these heartbreaking stories. It happens often.

The main take-away from reading these stories is the all-consuming guilt these people feel. Not only do they feel guilt, but their families feel ashamed too. A dark cloud forever exists over the offender's family. Many of the drunk drivers plead guilty. They readily accept the punishment they receive to feel like they have adequately repented. Most of the stories online are from people who have somewhat overcome this tragic fate.

\footnotetext{
44 Nicole LaFreniere as told to Jessica Kowal, "I Drove Drunk and Killed Three People,” Cosmopolitan Magazine, Dec. 3, 2015, https://www.cosmopolitan.com/lifestyle/a50255/three-people-killed-drunkdriving-story/ (accessed April 12, 2018).

45 Bethany Vaccaro, “Drunk Driving: 'I Drove Drunk and Killed Two Sisters,"” Glamour Magazine January 2, 2011, https://www.glamour.com/story/drunk-driving-i-drove-drunk-and-killed-two-sisters (accessed April 12, 2018).
} 
The stories of those that succumb to the guilt are not present. I imagine I would be one of those people. I do not know if I could handle it. Again, I feel very lucky.

So, what would it be like to kill someone while drinking and driving? That was the original "prompt' for Sliding into Home. Using that prompt, I began to create the story of a family afflicted with the aftermath of a drunk driving accident. However, I needed something else. I needed more specificity. In the playwriting classes I teach, I tell my students often that "specificity is interesting." For example, in the case of Sliding into Home, if I was to just write about a family with characters that have no specific interests, characteristics, or differences, I would bore my audience. It would not be interesting. I needed something and that something became baseball.

It was a happy accident that my main character's name was Cobb. I had that name in my head for years as a potential name for a character in a play. In thinking about his name, I, in a moment of inspiration, connected his name to Ty Cobb, the famous baseball player. Now, I have always been a loyal and avid Kansas City Royals fan and they had just won the World Series in 2015, so I had baseball on the mind. In a rush, the play started to come together in my head. I would use baseball to make the play more specific. The character of Dale became clear; a father who almost made it to the big leagues, but his dream was unrealized. He then becomes determined to have sons that would realize the dreams he could not. With Dale's character set, I knew I had a play.

One thing I noticed in prison and continue to notice more and more in treatment and in the AA program is the impact of unrealized dreams. Once people are forced to deal with the fact that they are not going to become the person they hoped they would be, they try to numb themselves to their lack of progress. This is known as resentment. 
Norman Denzin states that "Resentment toward the past, toward others, toward the present and the future is felt. The repeated experiencing and reliving of this temporal and emotional attitude toward others and toward time itself characterizes the alcoholic self." 46 To summarize, alcoholics blame others for their "failures" and do not deal well with failure. This is something I wanted to explore in Sliding into Home especially because my own resentment of unrealized dreams, and my inability to let that go, was one of the driving forces behind my own lack of recovery.

I wrote Sliding into Home while a student in Dr. David Crespy's Advanced Playwriting. In this class, Dr. Crespy takes us through his Dreamwork Playwriting Seminar, which emphasizes non-linear technique, magical realism and theatricality. I welcomed the challenge of incorporating this technique into the play. The Dreamwork Seminar utilizes the act of experiencing dreams phenomenologically to create dramatic writing. Crespy states that dreamwork is "for any storyteller looking to transform their storytelling with the unexpected, the surprising, and the mysterious quality of dreams."47 While in the class, Dr. Crespy encouraged us to create a "dream cache." It is a brown, paper bag full of notes and memories from our dreams - and it was during this time of creating my dream cache that I realized I had a lot of dreams about drinking alcohol. These dreams, of course, were abstract, but they made me realize how my relationship with alcohol was deeply embedded in my subconscious. Though I did not pull this play directly from my dream cache, the class inspired me to experiment with a non-linear direction to reach the play's climax, poetic language, and having a ghost on stage. It also

\footnotetext{
46 Norman Denzin, Pg. 350

47 David A. Crespy, Dreamwork for Dramatic Writing [unpublished manuscript], (University of MissouriColumbia), 1.
} 
taught me that just because a play is a tragedy based on very real experiences, it does not mean it cannot be magical.

Using non-linear techniques was, perhaps, the most challenging aspect of the dream seminar to wrap my head around. I remember when I figured out how I was going to create a non-linear plot. I will never forget the moment, sitting in class, that it hit me what if Cobb was not driving? What if J.D. was driving and Cobb took the rap? I could not believe the thought came into my head. I had surprised even myself. I could not wait to write. I knew I could write the play through flashbacks to the night of the accident to leave bread crumbs that would lead to the ultimate truth and answer the major dramatic question: To what lengths will sons go to please their fathers? I will say that this moment was when, for the first time, I truly considered myself a playwright.

Non-linear technique can make a linear story more explosive and impactful. In his book, Playwriting in Process, Michael Wright contends that "separating plot from structure is crucial. The two are often linked together as if identical, but nothing could be further from the truth. Plot is what you wish to show an audience; structure is how you intend to show that plot." 48 With this in mind, I created a plot that told linearly would seem traditional in structure. However, through flashbacks and "dream sequences" interjected into the plot, I could create a non-linear structure that continually informs the plot. By jumping back in time to the night of the accident, suspense is created concerning what happened on that fateful night.

At this point, I needed something to tie it all together. I knew that J.D. was going to appear as the "dead brother" and talk to the audience. I decided that he would be an

${ }^{48}$ Michael Wright, Playwriting in Process, (Newburyport: Focus Publishing/R. Pullins Company, 2010), 101. 
appreciator of poetry and recite poetry. I tried to write some poetry for him, but it was not working. Then I remembered a poem that a classmate performed when I was high school. The name of the poem was Casey at the Bat. I looked it up and read it. I was amazed at how well it fit into the story — if one reads the play and the poem closely, a parallel narrative can be recognized.

Additionally, the poem was used to enhance the magical realism of the play. J.D. recites the poem during his monologues in which he addresses the audience. His use of the poetic language fights against the abrasive language used in much of the rest of play, giving his scenes a more dream-like feel. The poem is also used specifically to tie in Americana and the popularity of baseball as a representation of America's sportsobsessive culture. The poem acts as a deliberate metaphor for the pervasiveness of alcohol, like sports, in American society.

The use of the dynamics of the father/son relationship in playwriting is not an original idea, but it is an effective one. Influenced by Arthur Miller's Death of a Salesman, which also uses non-linear technique to tell the story of a father's unrealized dreams and the effects it has on his sons, Sliding into Home explores this theme as well. The use of the father/son dynamic is a familiar, relatable relationship for audiences as evidenced by the myriad of plays, movies, television shows, and narrative works that explore this relationship. One unique thread of the relationship of the father to his sons in Sliding into Home is that one of his sons is an adopted African-American. The Stewarts (the last name of the family in the play) are rumored to have adopted him because they thought he would be a good athlete. By adding this character, whose name is Kal, I added a different perspective, language and voice to the play. Additionally, since Kal does not 
possess the genetics of his father, he is not genetically inclined to be an alcoholic or addict.

Sliding into Home possesses a "twist-ending." These types of endings can be problematic in that they are not always successful. If an audience member figures out the twist early, then they may disengage from the performance. In writing the play, I was careful not to give too much away, though hints at the ending exist throughout. In the two readings of the play so far, over ninety percent of the audience did not see the end coming. I consider this a successful twist.

The writing of the play happened quickly for me. Over the course of a few weeks, I would sit and write, and write, and write. I could not wait to get back to the play and tell the story of this family. It was a heart-breaking play to write. An artistic journey like no other I have ever had. One that ultimately led to a play, which I think is engaging and powerful. Most of all, I am pleased with how well it reflects the reality of a family dynamic and the effects of unrealized dreams.

After completing the first draft, the further development of Sliding into Home occurred over the course of six months. The first workshop I had of the play was in my Advanced Playwriting class wherein I was given feedback by my peers and my professors on how to improve the play. At that point, much of the concern with the play was about the character of Juana, Kal's girlfriend, who is white but wants to be Latina. Some people in the workshop were confused and found her character offensive. However, they were mistaken in thinking she actually was Latina. I revisited the script to ensure this was clear. Overall, the feedback in this workshop was extremely positive. Additionally, the play was performed as a staged-reading as part of the 2016 
Mizzou New Play Series. The feedback there was positive. It was there I was ensured that my use of Casey at the Bat was an effective choice as a few people in the audience related to the poem and were positively impressed by how I wove it into the narrative. The response I received from this performance granted me self-permission to ultimately (or at least temporarily) lock the play.

In December of 2016, I was informed that Sliding into Home was a semi-finalist for the Eugene O'Neill National Playwrights Conference. This meant is was in the top 200 plays of over 1200 plays submitted. This was further assurance that the play works on several levels; however, as it did not advance past the semi-final round, I feel I need to revisit the play at some point to get it to the next level. In revision, three specific elements of the play would change: the setting, the structure and the language. This may seem like a complete overhaul, but it is not. The story is not going to change, and the intent of the story is not going to be altered, but there are some practical revisions I can make that would strengthen the play.

I would like to change the setting to a more dream-like, expressionistic set. This set would be a baseball field in which all the action takes place. This would include the scenes at the bar, the living room, etc. The reason for this is to provide the audience the perspective of watching the Stewart family's struggle as if it were a sport, a game, and the audience are the spectators. This amplifies a metaphor of how society watches people suffer and on one hand, do nothing about it and the other and more extreme, watch for their own entertainment and enjoyment.

Structurally, I want to look at the journey of each woman in the play. I would like to introduce Juana and Marcy earlier to allow these characters an arc. Right now, Juana 
and Marcy enter toward the end of the play and both act as characters to further plot. I want them to be more than that-I'm not sure how, but I feel the play needs that. Also, I want to develop Sharon's story further. Her desire to want a more fulfilling life is an important aspect of the overall story and more attention should be paid to it. Overall, I do not believe I gave the women of the play the time they deserve, and I want to remedy that. They have been incredibly affected by the alcoholism, addiction, unfortunate actions, and personalities of the men in the family, so they deserve as much.

Finally, I want to make the language of the play more specific. In particular, I want to use the specific language and jargon of baseball in the bar scene flashbacks with Cobb. Cobb will ruminate on specific aspects of baseball as he drinks, which could be used as metaphors for the scene that follows. This specific language will make the play more interesting. Additionally, specificity about baseball will be key in allowing the audience to understand how much Dale's obsession with baseball has affected his family. Even though he has sworn off playing baseball, Cobb cannot stop talking about it. Knowing that I need to learn more about baseball has been a great gift - it simply means I need to watch it more and go to more Royals games! 


\section{Sliding into Home: A Play in Two Acts}

By Aaron Michael Scully

Copyright Aaron M Scully 508 Fountain Hills Dr.

Warrensburg, MO 64093

(660) 924-6304

aaronscully76@gmail.com 


\section{Characters}

Ty Cobb Stewart (Cobb) - white male - Ages 23 and 27

Sharon Stewart - Cobb's Mother - Age 56

Dale Stewart - Cobb's Father - Age 58

Marcy Stewart - Cobb's sister - Age 24

Calvin Ripken Stewart (Kal) - African-American Male -Cobb's adopted brother - Age 17

Juana - White, but wants to be Latina - Kal's girlfriend Age 16

Joe Dimaggio Stewart (J.D.) - Cobb's brother - died at age 21

Time:

Present and four years prior to the present

Setting:

Naperville, IL, a suburb of Chicago. The action takes place in the living room/dining and backyard of the Stewart home and the interior of a bar.

J.D.'s action takes place in a time and place that exists only in our imaginations. 
Setting: The living room/dining area of the Stewart home. It is middle-class, which is apparent by the consolidation of the living room and dining area. The room consists of a couch, love seat, La-Z-Boy, coffee table, and a dinner table that seats six. Perhaps the living room is more to stage right and the dining area more to stage left. The room exists as one and is decorated accordingly. Family pictures adorn the walls. Baseball artifacts (trophies, encased baseballs, bats) intermingle with shelves of books (novels, classics, recent best-sellers) around the room. This may seem an odd juxtaposition, but the decorating is sensible and intelligent. Against one wall is a liquor cabinet containing assorted bottles of liquor. A door exists upstage that goes to the rest of the house. Stage right is the front door. Additionally, there should be a playing area that acts as a backyard and an area that acts as the bar Cobb is in during the flashback scenes. These two playing areas can just be suggested with minimal set pieces. However, it is, of course, up to the creative team how this is done.

\section{Act One, Scene One}

Time: Four years ago.

The first scene takes place downstage right. A bar sits in the downstage right area. The bar is not part of the Stewart home and should suggest that it is a bar in an establishment of some sort. The sounds of a baseball TV commentator calling a game is heard coming from a TV which the audience does not see. Two bar stools sit behind the bar.

Ty Cobb Stewart, otherwise known as Cobb, sits on one of these stools. A Bombay Sapphire and tonic and an empty shot glass sit on the bar in front of him.

Lights rise on bar only.

Cobb is a handsome twenty-three-year-old. He sips his drink. He pulls out a cell phone, looks at it, and sets it on the bar. He downs the rest of his drink. It is his first drink of the night. He is not drunk. Yet.

\section{COBB}

Barkeep! Excuse me. Excuse me! Can I get another Bombay when you get a minute? Bombay Sapphire. Yes. And tonic. With a lime. Thanks. (beat) What's that? Yeah, sure. Why not? Another tequila couldn't hurt. (to himself) A little tequila never killed anybody.

Cobb picks up his phone again. He looks at his watch. The sounds of the baseball game seem to be getting louder.

\section{COBB (CONT'D)}


Hey, would you mind changing the channel? Or just turn it off? (Beat) Yeah, I know it's the Cubs, but I'm the only one in here and I'd rather not watch it. (beat) Yeah, that's right. I don't like baseball. (beat) I know, I know. Wrong town to hate baseball. (Beat) Could you at least mute it then? (to himself) Both teams suck anyway.

The sound of the TV instantly goes away. Cobb grows impatient. He picks up his phone and dials. He waits for someone to answer. The person answers.

\section{COBB (CONT'D)}

Hey. Where are you? I told you seven-thirty! (beat) No. No, no, no, no, no. Don't hang up. Hey! Yeah, look. Come on. It's not a big deal. (beat) Sabermetrics, huh? Oh yeah? It's statistically impossible, huh? Little brother, you should know, more than anybody, that anything can happen. It's baseball. Somebody is gonna win and somebody is gonna have to lose. (beat) Listen. Just don't stop at his... (beat). Okay, Okay. Just get here.

Cobb hangs up. Places the phone on the bar.

Bartender! That drink!

\section{COBB (CONT'D)}

He picks his phone up again and looks at it. Puts it back down.

Shit.

\section{COBB (CONT'D)}

The lights on the bar fade. Cobb exits. The bar disappears.

\section{Scene Two}

Time: Present

Lights up on the Stewart home. Sharon Stewart enters. She carries a bottle of Windex and a rag. She places the Windex and rag on the coffee table and fluffs the pillows of the couch. She picks up the rag and Windex and crosses to a row of trophies. She dusts them. As she is doing this, she starts to hum a little. Perhaps she hums Tracy Chapman's "Give Me One Reason" or something like it.

Sharon's humming turns into all out-singing.

She finishes the trophies and crosses to the pictures on the walls. She starts dancing a bit and squirting the pictures with Windex. She is getting into it now. She sings louder, dances, squirts Windex and polishes.

She polishes a picture of her family and pauses a little. She pulls it off the wall. She looks at it and continues to sing, but a sadness enters her voice. 
She repeats the same line of the song a few times. It gets sadder and quieter. She is mesmerized by the picture and is engrossed in a memory.

There is a KNOCK at the front door! The knock startles Sharon and she drops the picture. The picture shatters on the floor.

Shit!

\section{SHARON}

Another knock. She stares at the broken picture and shattered glass.

\section{SHARON (CONT'D)}

Oh no.

Another knock. She turns and crosses to the door.

One second!

\section{SHARON (CONT'D)}

Sharon crosses to the door and opens it. Standing in the doorway is Cobb, but not the Cobb that we saw in the first scene. It is definitely the same person, but this Cobb has aged a little. His head is shaved, and he wears a black T-shirt, worn jeans, and prison issue shoes. He's in better shape. He has tattoos on his arms. He has a green knapsack flung over his shoulder.

\section{SHARON (CONT'D)}

Cobb.

\section{COBB}

Hi Mom.

\section{SHARON}

What are you ... ummm ... what are you doing? Here?

I got out a few days early.

\section{COBB}

\section{SHARON}

Oh.

\section{COBB}

I'm sorry, I just . . . It just happened. My C.O., he, well, he came and got me from my cell right before morning chow and told me my time was up.

\section{C.O.?}

\section{SHARON}




\section{COBB}

Oh, I'm sorry. The correctional officer. The prison guard.

\section{SHARON}

Oh.

\section{COBB}

(laughing) The I.D.O.C. - always full of surprises, huh?

\section{SHARON}

I guess so.

\section{COBB}

I just ... well, I got out early is all. Good behavior, I guess.

Oh. Well. That's nice.

\section{SHARON}

\section{COBB}

Yeah. No shit. I'm sorry I didn't call. I couldn't call. It was all happening really fast and I wasn't about to tell them to slow down so I could make a phone call. And there really aren't any pay phones anymore. I didn't even think about pay phones not existing. I didn't see one anyway. Well, I'm just sorry to show up unannounced like this.

Well, it sure is a surprise.

SHARON

Pause.

Ummm, come in.

\section{SHARON (CONT'D)}

You sure?

COBB

SHARON

Of course.

COBB

Okay.

They enter the house. This is very awkward.

Careful. I just broke some glass.

SHARON 
COBB

I'm sorry. Oh. It wasn't cause of me . . . I didn't ... I mean the knock, I didn't startle . . .

\title{
SHARON
}

Oh, no, no, no. Heaven's no. I broke it earlier. I just haven't got around to cleaning it up.

Pause for the Price is Right?

COBB

Pardon?

\section{SHARON}

\section{COBB}

You still uhh watchin the Price is Right every day? Not sure about that Drew Carey Barker's hard to beat.

\section{SHARON}

You remember. I . . . well . . . sometimes, I guess. But not every day.

\section{COBB}

I watched it religiously when I was ... God this is weird to say ... when I was locked up. It reminded me of you.

They let you watch TV?

\author{
SHARON
}

COBB

Sure.

SHARON

Oh.

\section{COBB}

Look, Mom, if this is making you uncomfortable I can come back some other time, or not at all. I don't know that I deserve to ... .

\section{SHARON}

Can I take your bag or sack or whatever it is and set it somewhere? It looks heavy.

COBB

Oh. This? Pretty fancy, huh? It's OK. I really . . . I . . . well I wasn't going to stay. I just thought I would stop by. And you know ... say Hi.

Pause. 
I'm sorry. This was mistake. I'm sorry, Mom.

\section{SHARON}

I just ... I'm not sure what to say.

\section{COBB}

Mom, I just, I well, I don't want you to think I came here expecting anything. I can go if you ...

\section{SHARON}

Oh. I didn't . . I just . . . I just can't believe your standing here.

\section{COBB}

I know. This day has been a long time coming. Feels like a dream.

A good dream, I bet.

\section{SHARON}

$\mathrm{COBB}$

Yeah. A very good dream.

\section{Pause.}

\section{COBB (CONT'D)}

I just really wanted to see you is all. I mean it's been . . .

\section{SHARON}

Four years.

\section{COBB}

Yeah. Four years. Well, almost. One thousand three hundred and ninety-nine days. Not that I was counting.

I would have visited.

\section{SHARON}

\section{COBB}

I know. There's just . . . I didn't want you to see me in . . . well I just, there's really just never a good enough reason to visit an Illinois State Prison. Believe me.

\section{SHARON}

I suppose. (beat) You know it's been longer than four years. I hadn't seen you in a couple months before the ... the ...

Accident.

$\mathrm{COBB}$ 
Yes.

\section{SHARON}

COBB

I'm sorry about that. I thought distance would be good. The press and all. Dad, you know, he was pretty pissed and I . . .

SHARON

I know.

\section{Pause.}

COBB

Well. I should get going. There's a halfway house that's got a bed for me not too far from here.

Okay.

\section{SHARON}

COBB

It's good to see you, Mom. I'm sorry for being gone for so long. And I'm sorry about J.D. I really wish I could have been here.

Me too.

\section{SHARON}

\section{COBB}

Mom. Umm, How about you? You been doing okay?

\section{SHARON}

Me? Oh, don't be silly. I'm fine.

\section{COBB}

You look good. (beat) Alright. Well. I'll be seeing you.

\section{Cobb turns to leave.}

Cobb. Wait.

\section{SHARON}

\section{COBB}

Yeah?

SHARON 
I mean you just got here for pity's sake. I haven't seen you in years. You just got out of . . . you must be dying for some real food. I could make you a sandwich. Turkey on wheat with mayo and mustard? Or maybe you could stay for dinner.

\section{COBB}

Dinner wouldn't be for a few hours.

\section{SHARON}

Well then you can stay for a few hours.

What about Dad?

\section{COBB}

\section{SHARON}

What about him?

COBB

Is he gonna be good with that?

\section{SHARON}

Why wouldn't he be?

\section{COBB}

Well, I . .

\section{SHARON}

It's settled, then. You'll stay for dinner.

COBB

I would need to call the halfway house and make sure it's okay.

Why?

\section{SHARON}

COBB

Parole.

\section{SHARON}

Uggghh. I hate hearing these words in this house. Parole and prison and all that.

\section{COBB}

I'm sorry.

\section{SHARON}


It's fine. It's part of our lives, now, I guess. These words. Prison, parole, involuntary whatever. All these words. I just never thought they'd be part of my, well, part of my lexicon.

You're what?

COBB

SHARON

My lexicon. You know, my vocabulary.

COBB

Yeah. I know what it means. I just ...

SHARON

I've been taking classes a N.C.C.

COBB

No shit?

SHARON

Language.

COBB

Sorry.

SHARON

I have been. For a while now. A couple of years. Four semesters and a summer actually.

COBB

What are you studying?

\section{SHARON}

English.

COBB

That's great, Mom. You always did love books.

\section{SHARON}

Yes. Well. I'm actually writing a collection of short stories.

COBB

Wow.

It's silly.

SHARON 
Cobb

No, it isn't. I've been doing a lot of writing myself. I'd love to read something of yours.

Really?

\section{SHARON}

COBB

Sure.

\section{SHARON}

Look. Why don't you have a seat? On the couch. I need to clean up this broken glass. Don't want anyone to get hurt.

\section{COBB}

You sure it's okay if I stay for a while?

\section{SHARON}

Yes. It's very nice to have you home. I'm just gonna grab the broom. (indicates the knapsack) Here let me take that. I'll put it in the bedroom.

COBB

That's okay, Mom. I'd like to keep it with me. It's everything I own in world.

SHARON

Oh. Okay. Suit yourself. Go ahead, sit.

Cobb sits on the sofa.

Would you like to watch TV?

SHARON (CONT'D)

\section{COBB}

No. No thanks. I'm good. I'd like to keep talking to you. I would love to hear about the classes you've taken. And the short stories.

Would you?

\section{SHARON}

COBB

Very much so.

\section{SHARON}

Well. I'll just be a minute.

Cobb stands. 


\section{COBB}

Can I help? I'm sorry, I should've ... .

\section{SHARON}

No, no, no. Don't be silly. Sit. Sit.

Sharon exits. Cobb sits for a moment and looks around taking in the room. He stands and crosses to look at one of the trophies.

COBB

(to off)

I take it Dad's not here?

\section{SHARON (OFF)}

He's at the ballpark.

COBB

Some things never change.

SHARON (OFF)

(overlapping)

Never change. I know. He spends more time there now than ever.

Still scouting future stars, huh?

COBB

(to off)

Something like that.

\section{SHARON (OFF)}

COBB

(to off)

Anybody good?

Sharon enters with broom, dustpan and small trash can and cleans up the shattered glass.

\section{SHARON}

A couple promising players. There's a lot more kids coming out from the inner city. Mostly in hopes that your father will work with them. There's this one kid, well, your father won't shut up about him. Names Andre or something. Black kid, of course.

Really? Does he know Kal?

\section{COBB}

\section{SHARON}


Kal? Why would he?

I don't know, I just thought ...

COBB

\section{SHARON}

What, because they're both black? All black people don't know each other, Cobb.

COBB

(laughs)

I thought maybe from playing ball.

\section{SHARON}

Kal doesn't play ball.

\section{COBB}

Really?

\section{SHARON}

Nope. After J.D . . . he well, he just didn't want to anymore. Of course, your father pushed him to stick with it, but ... It's too bad. He was good.

Better than J.D.?

\section{COBB}

\section{SHARON}

Oh yes. Better than you even.

\section{COBB}

What? J.D. was a way better than me.

\section{SHARON}

Don't be foolish. You know that's not true. You were always the best, you just chose a different path. If you don't like baseball, you don't like baseball.

\section{COBB}

I wish's you would of been that understanding when I was in high school.

\section{SHARON}

It was never me that wasn't understanding.

\section{COBB}

True.

\section{SHARON}

Mmm-hmm. 
COBB

And J.D. was always best. He was always better at everything.

\section{SHARON}

Now I know you know that's not true.

She pulls the picture from the broken frame and hands it to Cobb.

Hold this for a second.

\section{SHARON (CONT'D)}

Sharon exits with the mess. Cobb is left looking at a picture of his family.

How is Kal?

COBB

(to off)

SHARON (OFF)

Huh?

COBB

(to off)

How is Kal?

\section{SHARON (OFF)}

He's good. Senior year, you know. Don't see him much. He's got a serious girlfriend. Some white girl who thinks she's Hispanic. Goes by Juana. Her name is Jane, but she likes to be called Juana. It's ridiculous. I don't like her.

COBB

Yeah. Kal told me you weren't too big on her.

$\mathrm{Kal}$ ?

SHARON (OFF)

COBB

Yeah. Kal visited me last week.

Sharon enters. Sits.

What?

SHARON

COBB

Yeah. Just showed up. 
Really?

\section{SHARON}

\section{COBB}

Yeah. He told me a little about Juana, but didn't say much else. He definitely didn't tell me you were taking classes at N.C.C. Didn't tell me he wasn't playing baseball either.

Then what did you talk about?

\section{SHARON}

COBB

Not much, really. He got there with like fifteen minutes left in visiting hours. They wouldn't let him in at first because they didn't believe he was my brother. Something about being my adopted brother and not a blood relative. I'm sure it was more about him being black than anything. He kept asking me all these questions about what prison was like and then he said he had something really important that he wanted to ask me about. But the C.O.s came and got me. Kal isn't in any trouble, is he?

Not that I know of.

\section{SHARON}

COBB

Huh.

Yeah.

\section{SHARON}

COBB

Weird.

SHARON

Very.

Pause.

COBB

I'm sorry, Mom. This is a very strange day for me.

Me too.

SHARON

Pause.

COBB

Mom. 
Yes.

\section{SHARON}

Yes.

May I say something?

\section{$\mathrm{COBB}$}

\section{SHARON}

Of course.

COBB

I . . . well . . I just . . I'm very sorry for all that happened. I'm sorry about the accident. I hope you know I never meant for any of this. I'm sorry about J.D. I'm sorry that I didn't want you to come visit me. I'm sorry our family didn't turn out the way you wanted it to.

\section{SHARON}

You know, I never blamed you for anything. It was an accident. I was frustrated that you didn't want me to visit, but I understood. Didn't really have much desire to visit my son in prison anyway. I got your letters every few months and they were a comfort. (beat) J.D., though, I don't know what happened. A few months after you went to prison...God I've never been able to say that without wincing . . . "my son is in prison" . . oh well, but a few months after you went, he just started to change. His friends changed, he quit playing ball, he started using drugs. He just, he became a different person.

I tried to write him.

\section{COBB}

\section{SHARON}

I know. He just ... he got so ... lost.

Yeah.

\section{COBB}

\section{SHARON}

Well, I just ... I don't know. (beat) Let's change the subject. Something happy.

Marcy?

\section{COBB}

\section{SHARON}

I said something happy. Marcy is Marcy. A force to be reckoned with. Just got hired by a big marketing firm in the city.

You see her much?

\section{COBB}

\section{SHARON}


Hardly.

I wrote to her. She never wrote back.

COBB

\section{SHARON}

Not surprising. (beat) Maybe I can get her to come home for dinner for once. You know, to celebrate you coming home.

You think that's a good idea?

$\mathrm{COBB}$

SHARON

Why wouldn't it be?

$\mathrm{COBB}$

I don't know.

\section{SHARON}

It'll be great! Get all my children under the same roof for once. I think it may be just the thing this family needs.

Yeah.

$\mathrm{COBB}$

SHARON

Your family has never stopped loving you, Cobb.

Sure.

$\mathrm{COBB}$

SHARON

I'll go call them. Is there anything you need?

COBB

I actually need to call may parole officer still, if I could borrow a phone.

Sure.

\section{SHARON}

COBB

You know what I would love?

What?

\section{SHARON}




\section{COBB}

A coke. No. A Dr. Pepper. Do you have ...

We do! I'll get you one.

\section{SHARON}

COBB

That would be incredible.

\section{SHARON}

Well. This is pretty darn exciting.

\section{COBB}

I'm glad you're having fun.

\section{SHARON}

I am. Doesn't seem to happen too much lately.

Sharon exits. Cobb sits on the couch. Again, he looks around at his surroundings. He is almost overwhelmed with joy. On the other side of the dining table is a small liquor cabinet. He gets up and walks to it. He opens it. He pulls a bottle of Bombay from the cabinet.

Hello old friend.

\section{COBB}

Cobb opens the bottle and smells it. He considers taking a swig but doesn't. After a moment, he puts the lid back on and puts it back. He goes back to the couch and sits down. He looks around again. He smiles.

\section{COBB (CONT'D)}

(Calling out)

Mom, do you mind if I lay down on the couch?

What's that?

\section{SHARON (OFF)}

\section{COBB}

(Calling out, louder)

Do you mind if I lay down on the sofa? Been awhile since I've felt real cushions.

Of course not. Make yourself at home.

\section{SHARON (OFF)}

Cobb unties his shoes and takes them off. He sets them neatly by the couch. He lays back on the sofa. 
Lights fade to black for a moment then...

Scene Three

Time: J.D.'s world. There is no specific time.

A spot comes up downstage left. J.D. Stewart enters. He is the all-American young man. Handsome, chisel-faced, muscular and fit. He wears baseball uniform and a baseball glove. He tosses a baseball in the air and catches it in his glove. He addresses the audience.

J.D

The outlook wasn't brilliant for the Mudville nine that day; The score stood four to two with but one inning more to play. And then when Cooney died at first, and Barrows did the same A sickly silence fell upon the patrons of the game. A straggling few got up to go in deep despair.

The rest clung to that hope which springs eternal in the human breast;

J.D. begins to exit. But stops and turns back to the audience.

J.D.

Yes. Poetry. Poetry, like baseball, can be an acquired taste. But not to worry. Something is bound happen soon. The ball is in play.

He exits.

Lights fade to black.

Scene Four

Time: Present.

Lights up on the Stewart home.

Dale Stewart, Cobb's father, is standing over a sleeping Cobb looking down at him. He watches him sleep for a moment, then pokes him with a baseball bat.

DALE

Wake up.

He nudges him again.

Hey. Cobb. Wake up.

\section{DALE (CONT'D)}


Cobb pops up. A prison reaction. He swipes the bat from Dale's hands, raises it, and is about to swing.

Back motherfucker!

\section{COBB}

Dale puts his arm out to stop the attack.

\section{DALE}

Whoa! Hey!!!

COBB

Oh shit. Dad.

DALE

Cobb.

COBB

Shit.

DALE

Now there's a greeting.

COBB

Sorry. Second nature.

DALE

For a criminal, I guess it would be.

COBB

Sorry. I'm sorry.

DALE

What the hell are you doing here?

COBB

Just came by to say hi to Mom. And you.

Sharon!!!

DALE

COBB

I'll go.

DALE

Good. Sharon!! 
COBB

Okay then. I see you are still pissed.

\section{Sharon enters.}

Hi Dale.

\section{SHARON}

DALE

Sharon. What is this person doing in my house?

You're home early.

SHARON

DALE

Rain. Did you let this in here?

SHARON

Of course.

DALE

Really?

SHARON

Dale. Don't.

COBB

Look, Dad, I can just go. I know I ...

DALE

Shut up.

\section{SHARON}

Dale, please.

\section{DALE}

Tell me, son, what do you think gives you the right to sleep on my couch. Does this look like some sort of flophouse for convicts?

Dale.

\section{SHARON}

COBB

(overlapping)

Yeah. I'm gonna go ahead and go. 
Cobb grabs his shoes and is ready to leave, but his bag is on the floor behind his father. He stops.

\section{COBB (CONT'D)}

My bag.

DALE

You think you can just come in here and everything is gonna be just hunky-fuckin-dory, huh?

Dale.

\section{SHARON}

COBB

No. That's not . . look, I just need my bag and I can go.

DALE

You shit for brains. What made you even consider that this would be okay? Huh?

Dale.

\section{SHARON}

COBB

My bag. Please.

DALE

You are fucking unbelievable. Prolly a faggot now too, huh?

Dale! Stop it!

$$
\text { SHARON }
$$

\section{COBB}

That's enough.

DALE

What? Am I right? Prison turn you into a sissy boy?

Watch yourself, Pop.

\section{COBB}

\section{DALE}

Am I right boy, you turn fag on us?

\section{COBB}

Your pushing it, old man. 
DALE

What are ya gonna do, hit me?

\section{SHARON}

Just give him his bag. Please, Dale.

Dale picks up Cobb's bag.

\section{DALE}

What? This?

COBB

Give it to me.

DALE

What you got in here, drugs? Fag porn? Some shank souvenirs?

Dale, this is preposterous!

\section{SHARON}

DALE

Enough with the big words, Sharon!

COBB

My bag. Now.

Dale hands him the bag.

DALE

Now get the hell out of my house! Now.

COBB

I'm sorry, Mom.

\section{SHARON}

I'm sorry too.

Cobb begins to exit.

DALE

Yip-fucking-eee. We're all sorry! (to Cobb) This is your fault you know.

Stop it!

\section{SHARON}

COBB 
Excuse me.

DALE

One at bat and you couldn't get one lousy hit.

COBB

You have got to be kidding me. Not this shit again. You are a ridiculous human being, you know that?

\section{DALE}

One lousy hit. And you blew it! If you'd a hit that ball, you'd of been a champion. J.D. would have been a champion. Damn noodle-armed pitcher was throwing up ducks and you whiffed'em. Three in a row.

COBB

I can't believe . . . all that's happened ... and this is what you bring up.

DALE

You are the definition of a loser. Loser. Alcoholic. Criminal. A goddamn loser.

COBB

You need to let it go. Really, Dad. Let it go. Bye, Mom.

I'm sorry, Cobb.

\section{SHARON}

DALE

Let it go? It's gone! It's been gone! Til you had to show your face here again. If you'd a hit that goddam ball...

\section{COBB}

Jesus Christ. Listen to yourself. Five years. It's been over five years since that stupid game.

DALE

Champions are champions. You, son, are no champion. Your brother could have been, but you, you are a loser.

Dale. That's enough.

\section{SHARON}

COBB

I'm leaving.

\section{DALE}

Good. Walk away. That's what losers do. 
I missed on purpose.

What?

COBB

I said I missed on purpose.

DALE

I'm sorry.

COBB

I missed on purpose! I struck out on purpose!!!

DALE

No you didn't.

COBB

I did.

\section{DALE}

No way.

COBB

I coulda pummeled those pitches. Rocketed 'em. It was like batting practice. Pitcher's arm was like rubber. Three floaters right down the middle and I missed 'em all. On purpose.

Bullshit.

DALE

Bullshit.

I missed on purpose. Live with that.

COBB

DALE

Get out!

Yep. I missed. On purpose.

COBB

DALE

You did not.

COBB

I did. 
This is horseshit.

\section{COBB}

J.D. was on deck. I was sitting next to him in the dugout. I remember like it was yesterday. That kid Lewis was up first and struck out. Grady bunted on. Good call on your part, Coach Stewart. Stevie Frills was up and I was on deck. Right before I took the field, I looked back at J.D. and he looked at me and said, "Strike out. Please." He had this look on his face, this look of terror. The whole time I was on deck, I kept looking back at him and he was just staring into space, terrified. Horrified. Scared. (beat) Kirk Johnson was up next. Ole K.J. Accidental Sac fly. Second baseman dropped the ball on the relay and Grady made it to third. All I had to do was get a base hit. Just get on base. As I was taking my practice swing, I looked back at the dugout and J.D. looked at me. I could see it, shimmering in the sun, a tear falling out of his eye and onto his cheek. He was scared, Dad. He was really scared. And I'm his big brother, so I struck out.

What was wrong with him?

\section{SHARON}

\section{$\mathrm{COBB}$}

I don't know.

\section{DALE}

You don't know? You say you don't know? This is bullshit. Horseshit. And a whole lot of it. No son of mine would have thrown a ball game.

\section{Cobb laughs.}

\section{DALE (CONT'D)}

What's so funny? This is uhhh ... what do they call it? Criminal behavior. It's like a mental problem. A disease. Half the boys at the park got it. You're just a born liar. I mean, Jesus Christ, you just got out of prison - what should we expect?

\section{COBB}

Nothing. And you're right. I've been in prison for four years and out less than four hours. I don't need this.

\section{DALE}

That's it. Walk away. Pussy. Quitter.

COBB

You want me to swing on you, don't you? That's what you want, isn't it?

You ain't got the guts.

DALE 


\section{SHARON}

Dale, please. Cobb, I want to talk to you about J.D.

\section{DALE}

Nothing to talk about. Cobb here is a fucking loser. And that's that.

\section{COBB}

Say that again.

DALE

What? Loser.

\section{$\mathrm{COBB}$}

Yeah.

DALE

You are a loser.

Cobb has had enough. He steps to his father.

COBB

Again.

DALE

Loser.

\section{SHARON}

Please stop this.

COBB

Don't push me.

DALE

Go ahead.

\section{COBB}

God damn you ...

Cobb steps up and cocks his fist back. He holds it for a moment. He's about to swing when the front door opens. Kal bursts in and sees Cobb.

Cobb!

\section{KAL}

COBB

Kal. 
Cobb lowers his fist. Kal, in his excitement to see his brother, is oblivious of the tension in the room. He runs over to Cobb and bear hugs him.

KAL

Holy shit, man. You're out. Oh, man, it's good to see you! I can't believe you're ... what, you get out early?

$\mathrm{COBB}$

Yeah.

DALE

Kal.

What, Pop?

KAL

DALE

Cobb was just leaving.

\section{KAL}

Leaving? But he just got here! How long you been home?

COBB

About twenty minutes.

KAL

How long you been out?

\section{COBB}

About four hours.

KAL

Wow. Holy Shit!

\section{SHARON}

Kal. Language.

\section{KAL}

Sorry, Mom. Wow this great! Four hours, huh? After four years . . man, you must be about ready to burst out your skin! I would be like ... man, "get me a woman, a beer, a burger, a steak, a woman" Wow. It's good to . . .

Kal, would you shut up!

\section{DALE}

KAL 
Whoa, Dad. What's up your ass?

DALE

He's not welcome here.

What?

KAL

COBB

It's cool, Kal. We can catch up some other time.

KAL

Other time? What are you talking about? You're not staying here?

COBB

No.

Mom?

KAL

SHARON

It's not ...

DALE

Your brother is a . . a . . a . . murderer. I won't allow a murderer under my roof.

KAL

Murderer? Dad, what's going on with you? That's a bit harsh, don't you think? Cobb isn't a murderer. It was an accident. Involuntary vehicular manslaughter. Cobb never meant to hurt nobody. He isn't a criminal.

You don't understand, Kal.

DALE

KAL

Understand?

DALE

It's above your pay grade.

\section{KAL}

Pay grade? Dad, you sound like a dick. You need a nap or something? Look Cobb, I don't know what's up Dad' ass, but it is damn good to see you. Come on man, tell me all about the "big house." You didn't get turned out did ya?

\section{SHARON}


I thought he . . .

Sharon realizes Dale doesn't know Kal went to visit Cobb and stops before she says too much.

... sent you letter.

\section{SHARON (CONT'D)}

\section{KAL}

Uhh, yeah. But I want the real dirt. You have to shank anybody?

$\mathrm{COBB}$

Look Kal, Dad isn't real comfortable with me being here, so I think I should probably go.

KAL

Oh, don't pay any attention to Pop. He's just a hothead sometimes. Surely, he wouldn't kick my only living brother out into the street before we even get a chance to catch up. Would ya, Dad?

Dale.

\section{SHARON}

Yeah, come on Dad.

\section{KAL}

\section{DALE}

You know what? I'm going for a walk. I need to clear my head.

\section{KAL}

Take an umbrella, Pop. It's gonna rain soon.

Dale looks at his family. He realizes he's the odd man out.

Gone when I get back.

DALE

KAL

Hey, Pop, maybe while you're out walking you can try and jiggle that gigantic stick out of your ass.

\section{SHARON}

I'm making lasagna for dinner, Dale. And Marcy is coming over.

\section{KAL}

Ahh, hell yeah! Moms has got the bomb lasagna. 
What?

Sharon walks Dale to the door. She whispers to him.

\section{SHARON}

Marcy is coming for dinner. Now I don't know what the hell your problem is, but maybe, while you're out, you can try and come to your senses. If you could find it in your heart to let Cobb stay for dinner, it would mean a great deal to me. I have dreamed of the day that I could have all my children together again, and that day has finally come.

\section{DALE}

Not all your children.

\section{SHARON}

Yeah, well. Come on, doesn't it sound a little bit nice?

\section{DALE}

Sounds like a God damn train wreck.

Dale looks back at his sons. He looks at his wife. He leaves.

What's his deal?

\section{KAL}

COBB

His problem is me. He's got a right to be pissed.

Yeah, but for four years?

\section{KAL}

COBB

Dad can hold a grudge.

\section{SHARON}

He sure can. You okay, Cobb?

\section{COBB}

Yeah. A little rougher than I expected. I'm glad you walked in when you did, Kal.

Why?

$$
\text { Kal }
$$

\section{COBB}

Things were getting pretty hairy between Dad and me. 
Oh. You mean like ... ?

\section{KAL}

\section{COBB}

Yeah.

KAL

You'd a kicked his ass. Look at you, all buff and blown out.

\section{Kal grabs Cobb's bicep.}

KAL (CONT'D)

White boy's got some guns. Man, it's good to see you.

SHARON

It's been awhile, has it?

KAL

It sure has.

\section{SHARON}

Is that so?

KAL

Mom, why you being so ... oh shit ... you told her?

\section{COBB}

I didn't know it was a secret.

KAL

Shit.

\section{SHARON}

Language.

KAL

Sorry, Mom. I just didn't want you gettin all upset and wanting to go visit too. That's all.

SHARON

Cobb thinks you might be in some trouble. Are you?

Trouble?

KAL

\section{SHARON}

Yes. Trouble. 
KAL

Me. In trouble. Shoooooot. I'm squeaky clean.

\section{COBB}

Then why'd you wanna know what prison was like? You seemed nervous. We hardly had a chance to talk by the time the guards came and got me.

KAL

What black man don't get nervous at a prison? I wanted to see my brother, that's all. Really.

You're lying.

\section{SHARON}

\section{KAL}

(playfully)

Me? Lying?

\section{SHARON}

Yep. I don't know what about. But you're lying.

KAL

So, Lasagna, huh? I'll call Juana.

\section{SHARON}

What? No, no, no, no, no, no. This is going to be a family dinner. No Juana.

But Mom, I love her.

KAL

(like a puppy dog)

\section{SHARON}

No.

KAL

Please.

\section{SHARON}

No.

KAL

Pretty please. I swear she won't talk too much.

That'll be the day.

\section{SHARON}


KAL

She won't talk. She'll be too busy shoveling your kick ass lasagna down her pie hole. C'mon, Mom.

Oh, all right.

\section{SHARON}

KAL

Awesome. Wait til you meet her, Kal. She's a total freak.

What?

SHARON

KAL

That's a good thing, Mom.

\section{SHARON}

Alright, well Marcy is going to be here at six. I better get started on the food.

COBB

Marcy's coming?

\section{SHARON}

She sure is.

KAL

She's a freak too.

SHARON

Kal.

KAL

It's a good thing!

COBB

You think I should stay? I mean Dad was pretty fired up. The whole murderer thing was a bit much.

KAL

Yeah, but you aren't a murderer. It was an accident, right? You just drank too much. Could happen to anybody.

No. Not anybody. Just idiots.

COBB

KAL 
Huh. (beat) Well don't worry about Pop. You should hear him down at the ballpark. Sounds like General Patton rallying the troops.

Patton, huh?

\section{COBB}

KAL

Yeah. All like, "listen you little pussy maggots, you will fight to the end!" He's totally losing it.

Kal. Be nice. He'll calm down.

\section{SHARON}

\section{COBB}

Alright. But if things start up again, I'm leaving. No arguments.

\section{SHARON}

Fine.

KAL

Ah, dude. It'll be totally chill. Trust me.

\section{SHARON}

You still need to call the uhhh ...?

COBB

P.O.? Yeah.

SHARON

In the kitchen.

$\mathrm{COBB}$

Okay.

KAL

I'll call Juana. She's gonna be siked. Her Mom don't cook shit.

Language.

SHARON

Shit. Sorry. I mean. Sorry.

\section{KAL}

SHARON

Cobb? 
COBB

After you.

Cobb turns to Kal.

\section{COBB (CONT'D)}

It's good to see you little brother.

You too.

\section{KAL}

They embrace. Cobb grabs his bag and follows Sharon to the kitchen. Kal takes out his phone and calls Juana.

\section{KAL (CONT'D)}

Hey, baby. Sorry. I mean, Hola, Juana. Como esta? Sorry, como estas? (beat) Guess what? Lasagna tonight. I know, straight up mackin. And guess what else. My brother's home! Yeah. My big brother. Got out early. Yeah. He's white. Cause I was adopted. I don't understand how you don't understand. I was adopted when I was a baby. Why? Because my Dad thought it would be a good idea to adopt a black kid. I've told you this like five times. Yeah. Well, maybe if you weren't always staring at your damn phone when I am trying to talk to you. Yeah. Lasagna. Prolly salad too and rolls and all sorts of shit. My mom - she's like Chef Boyardee on steroids. Okay baby ... yeah about six. I can't believe my brother is finally home.

\section{Blackout.}

\section{Scene 5}

Time: Four years ago.

Lights up on Bar.

Cobb sits at the bar. He now has two empty glasses in front of him. He checks his watch.

What's that? I probably shouldn't.

\section{COBB}

He looks at his watch and checks his phone.

COBB (CONT'D)

You know what? I can handle one more.

After a moment, his phone buzzes on the bar. 


\section{COBB (CONT'D)}

Yeah. Where are you? On your way. That's what you said a half hour ago. You're gonna be another ten minutes? Look. Let me explain something to you. If you want this, if you need this, then you will come to the bar, now. I mean right now. And get it. You're lucky I just ordered another drink. You got ten minutes or I'm gone. Gone, little brother, I'll be gone. Gone, gone, gone.

He hangs up the phone.

\section{COBB (CONT'D)}

I should've hit the damn ball.

Lights fade.

\section{Scene 6}

Time: Back in J.D. 's world.

Lights up downstage left.

J.D. enters. This time he carries a baseball bat. He takes practice swings and addresses the audience.

\section{J.D}

I remember the first time I made contact. When my bat hit the ball. It was like magic. Of course, I didn't understand it then. You know? The physics of it. The velocity of the ball. The fluidity of the swing. The angle of the bat. The firmness of the stance. The speed. (beat) I was enraptured. It was at that moment that I understood my Dad. Totally understood him. That magic - it's like a drug to him. The worst kind of drug. It got him high for a while, but now he can only stand there and watch while others get high right in front of him. Torture. Anyway, more poetry: Where were we?

Then from five thousand throats and more there rose a lusty yell;

It rumbled through the valley, it rattled in the dell;

It pounded on the mountain and recoiled upon the flat, For Casey, mighty Casey, was advancing to the bat.

J.D. exits with the bat over his shoulder. He whistles "Take me out to the Ballgame."

Lights fade. The Stewart home is still visible, minus the family picture.

End Act I 


\section{Act Two, Scene One}

Time: Four years ago.

Cobb sits at the bar. He is half-intoxicated.

COBB

\section{(As if talking to the bartender)}

Yeah. I said Dale Stewart. No, Dale Stewart. Yeah. He's my Dad. My father. You've heard of him? You're shittin me? He only played for the Cubs for like a week. He had one hit. No Ribbies. Batted exactly one hundred. Went oh for nine and on his tenth at bat got a triple. Played only five games in the majors then, BOOM!! - he blew his knee sliding into home. (beat) Nope. Never scored a run. (beat) Yeah, that's right. Right fielder. Impressive - you sure know your baseball. (beat) What's that? Oh. Well, he spent a couple years trying to rehab his knee, but it was never the same. Got married. Popped out a few pups including yours truly and ... what's that? He's a high school teacher and baseball coach. Gonna retire soon. At least, so he says.

Cobb's cell phone rings.

\section{COBB (CONT'D)}

Cobb here! Good. Good. See you in a minute.

\section{COBB (CONT'D)}

Bartender. Another Bombay please. And a Vodka soda and two shots of tequila. My brother's on his way. You should meet him. He's a helluva ball player. As good as my father? I don't know. Never saw my Dad play. Only coach. My brother J.D. though, he'll be famous someday. He'll be the son my Pop always hoped he would have. A majorleaguer. A star. He keeps trying to fuck it up. But I won't let him. No sir. He will be a star. I'm sure of it.

Lights down on bar.

\section{Scene Two}

Time: Present

Lights up on the Stewart home. J.D. stands in the middle of the living area holding a trophy. He is still in a baseball uniform, but it is halfway untucked. He looks somewhat disheveled. 
J.D.

(Addressing the audience)

Second place. Illinois State championship. The closest my father ever got to helming a championship team. If we'd of won, we would of went to nationals. Been on TV. ESPN. All that. So close. I remember watching my father when Cobb went up to bat in the bottom of the ninth. It looked like my Dad was inhaling victory. His barrel chest heaving in and out and in and out. We just couldn't win, though. We couldn't. I couldn't let us. It would of been the end of me. The end. I think, though, it marked the end of my father instead. It solidified his anger at his underachievement. (beat) I'm not sure why God creates big brothers like Cobb. Protectors. Guardian Angels. Life savers. Sometimes, though, I don't know if being protected from life is always the right thing. Sometimes, I think, you just gotta let life hit you. Like a wild pitch straight to the jaw.

J.D. replaces the trophy.

J.D

Casey. Casey, Casey, Casey, Casey, Casey. Would you like to hear more Casey? No? Yes? Some of you. Good. Where were we?

There was ease in Casey's manner as he stepped into his place; There was pride in Casey's bearing and a smile lit Casey's face. . I'm sorry. Somebody's coming. Gotta go. But don't worry, I'm on deck. Be up soon.

J.D. exits

Dale enters through the front door. He takes in the room, surprised there no one in the house. His focus, for some reason, is drawn to the trophy which J.D. was just holding. He walks to it and picks it up. He looks around as if he is going to get caught doing something he shouldn't. He replaces the trophy. He walks over to the empty spot on the wall where the family picture once hung. He drags a finger across the empty space on the wall.

Sharon enters. She has silverware to set the table.

SHARON

Oh. You're back.

DALE

I'm back.

\section{SHARON}

Good.

DALE

(indicating the empty spot)

What happened here? 


\section{SHARON}

Oh that. It fell off the wall and broke when I was dusting earlier. The picture hanger must have worn.

\section{DALE}

Huh. I'll get a new frame and hanger and hang it back up.

\section{SHARON}

That'd be nice. How was your walk?

Fine.

DALE

Where'd you go?

\section{SHARON}

DALE

I was headed to the ballpark but it started raining so I stopped at Shorty's and got a beer.

\section{SHARON}

Oh. You were gone awhile. It didn't rain long.

\section{DALE}

So?

So.

\section{SHARON}

So what?

DALE

\section{SHARON}

Nothing. I just ... I'm trying to put together a time line, I guess.

DALE

A time line? I swear this school stuff has changed you.

SHARON

I hope so.

\section{DALE}

What? Not happy with your life here?

\section{SHARON}

Don't be ridiculous. Don't you want your students to change? To become more enlightened? 


\section{DALE}

Enlightened? I just want them to shut the hell up and pass.

And play baseball.

\section{SHARON}

DALE

Play something. Be good at something. I never cared what.

And your own children?

\section{SHARON}

DALE

Oh come on, I just walked in the door. Can we just not argue? For a few minutes. I imagine this dinner tonight is gonna be a bench clearing brawl.

It'll be fun.

\section{SHARON}

DALE

We'll see.

\section{SHARON}

Yes. We will. So you went ...

DALE

I left here, I walked toward the ballpark, it started raining, I stopped a Shorty's, I drank some beers, it stopped raining and I walked home. Satisfied?

SHARON

Some?

DALE

Yes. Some. A couple of beers.

\section{SHARON}

Oh.

What's that? What's "oh."

DALE

SHARON

I just ... I just don't want you losing your temper again.

\section{DALE}

I don't lose my temper. 
Well you coulda fooled me?

\section{SHARON}

DALE

I just ... I don't understand how he thinks he can just waltz right back in here and everything is gonna be fine.

\section{SHARON}

He doesn't. Cobb is smarter than that, Dale. He's still our boy. Our son. He's had a pretty rough go of it, don't you think.

Well, he did it to himself.

DALE

SHARON

He never meant for any of this to happen.

DALE

Oh yeah, well what about him striking out on purpose?

\section{SHARON}

Dale. Seriously? Cobb has been in prison for four years and all you can think about is that stupid championship! He's been through more than I can imagine. He's dealing with the guilt of ending the lives of two innocent people. He lost his brother while he was in jail. Couldn't even go to his funeral. I happen to think he's doing pretty good, all things considered.

You think he's innocent in all this?

\section{DALE}

\section{SHARON}

Yes. Don't you? He's fulfilled a punishment that I'm not sure he even rightly deserved. Whatever sins he committed, he's served his penance and then some. I mean four years, Dale. Four years of prison. Don't you think that's enough. Don't you think it's time you forgive him? Forgive him for everything.

\section{DALE}

What about what he said about J.D.? Did he tell you what was wrong with him?

I didn't ask him.

\section{SHARON}

Why not?

DALE 


\section{SHARON}

Because Dale. What is it you are missing here? Huh? Our son got out of prison today. After four long years. I haven't spoken to him or seen him during that entire time. I have no idea what it was really like in there, but I imagine it was not very pleasant. I thought it might be nice for him to enjoy himself today. To enjoy his first day of freedom. Not grill him with questions about what prison was like, or his dead brother, or the night of the accident. The last thing I'm going to ask him about is why he struck out in a baseball game when he was in fucking high school!

\section{DALE}

Alright! I just ...

You just what?

\section{SHARON}

DALE

I just ... He ... he just shows up here like it's no big deal . . .

\section{SHARON}

He knows it's a big deal! He understands! He gets it! Why don't you?!

DALE

Okay. Just calm down!

\section{SHARON}

Can't we just have a nice family dinner? Is that so difficult?

DALE

Yes, Sharon. It is. This family ... this family ...

SHARON

This family is a family. And you need to treat it as such.

Fine.

DALE

SHARON

So you'll behave?

DALE

Yes.

And be nice?

SHARON

DALE 
Yes.

And no questions.

SHARON

DALE

No questions.

SHARON

Good.

DALE

Fine.

SHARON

Fine.

DALE

Good.

A pause.

Where is Cobb, anyway?

\section{DALE (CONT'D)}

SHARON

He's out back. Playing catch with Kal.

For the first time, we see Dale smile.

DALE

Catch? Whose glove is he using?

\section{SHARON}

J.D.'s.

DALE

It fit?

SHARON

Yes.

DALE

Huh. 
Dale walks to the window and looks out. As he is looking out the window, Kal and Cobb appear downstage, throwing a baseball back and forth. Sharon crosses over and looks out the window too.

The following is a split scene.

Cobb and Kal play catch while speaking. The continue to throw the ball while Dale and Sharon speak.

How's your arm?

\section{COBB}

KAL

Healthy as ever. How's yours?

\section{COBB}

Solid. I threw a bit on the inside.

\section{KAL}

No shit?

\section{COBB}

No shit. Actually put kind of league together. There's some good athletes in the joint.

Cool. You pitch?

\section{KAL}

\section{COBB}

Kind of. Had to use racquetballs and two by fours. Didn't have gloves. It was prison ball, you know.

Huh.

\section{KAL}

COBB

Made the best of the of the situation we were in.

I can't imagine.

KAL

COBB

It's impossible to imagine until you're there.

It was a total trip visiting you.

KAL 


\section{COBB}

Just promise me that's the last time you ever set foot in there. You don't ever wanna go for an extended stay.

Shit. No worries, Cobb.

\section{KAL}

You sure?

\section{COBB}

\section{KAL}

Yeah man. I'm going to college, not prison. Thinking about becoming a dentist or some shit.

\section{COBB}

Really? That's good to hear little brother. Very good to hear.

\section{Back to Sharon and Dale.}

You should join them.

\section{SHARON}

\section{DALE}

Naah.

\section{SHARON}

Well, if you're not going to, then help me set the table.

Sharon leaves the window and crosses to start setting the table.

DALE

Just give me a minute.

\section{Alright.}

\section{SHARON}

\section{Back to Cobb and Kal.}

KAL

Wish you wouldn't have told Mom I visited you.

\section{COBB}

You didn't tell me it was a secret.

\section{KAL}

Yeah, I guess I forgot that part. I wanted to, when I came to visit . . . 
What?

KAL

Ahh. It's nothin. You believe Marcy's actually coming home?

COBB

Nah. Should get interesting.

To say the least.

KAL

To say the least.

Did Bunt die while I was inside?

COBB

Yeah.

KAL

COBB

Dam. I loved that dog.

KAL

Yeah. He was cool.

COBB

So much happens in four years.

Yeah.

\section{KAL}

COBB

You guys thought about gettin another one? A dog, I mean.

KAL

I think Pop wants one, but Mom doesn't want to take care of it.

Mom's pretty smart.

\section{COBB}

KAL

Yeah.

Back to Dale and Sharon.

DALE

What do you think they are talking about? 
Who knows?

\section{SHARON}

DALE

Kinda different without Bunt chasing the ball back and forth.

\section{SHARON}

We aren't getting another dog.

\section{DALE}

I know, I know. At least they don't have worry about stepping in dog shit.

\section{SHARON}

Yeah. That's why we're not getting another dog.

DALE

Backyard doesn't seem so empty with the boys out there.

I'm sure it doesn't.

\section{SHARON}

Sharon returns to setting the table.

Back to Cobb and Kal.

So, this Juana girl. It serious?

COBB

Oh I don't know.

KAL

COBB

What did you say? She's a freak.

KAL

Ahh, I just say that. She's alright. She gets me, I think.

COBB

Man. Women. I miss them.

KAL

I bet.

COBB

You ever see Arianne? 
KAL

She's still around. I saw her at the Seven-Eleven like a month ago. She asked about you.

COBB

No kidding.

KAL

Yeah. She looked good. You should call her.

COBB

Maybe.

Back to Dale and Sharon.

SHARON

You wanna help me in the kitchen?

DALE

Just another minute, okay.

Sharon crosses back to the Dale and puts her arms around his waist.

SHARON

Our boys.

DALE

We're missing one.

SHARON

Yes. He's out there though. In some way, he's out there.

DALE

Maybe.

SHARON

I believe he is.

DALE

Sharon.

SHARON

Yeah.

DALE

Was this all my fault? 


\section{SHARON}

Yours? Why would you say something like that?

\section{DALE}

I feel like I fucked 'em up.

It wasn't your fault.

\section{SHARON}

\section{DALE}

I don't know. I just wanted ... I just wanted them to be great. They all had the talent. They just needed to be pushed, like my father pushed me.

\section{SHARON}

You wanting them to be good at something did not push that car over into the wrong lane. Cobb was drunk. That was it. That was all. He made a mistake.

\section{Yes, but J.D.}

\section{DALE}

\section{SHARON}

There was something else going on with J.D. I don't know what, but I have a feeling that Cobb does. We can ask him when the time is right.

DALE

How could they all end up hating baseball?

They don't hate baseball.

\section{SHARON}

Sharon gestures out the window.

Case in point.

\section{SHARON (CONT'D)}

\section{DALE}

Maybe I should apologize to Cobb for earlier.

Go apologize. Take your glove.

\section{SHARON}

DALE

You think?

\section{SHARON}

Sure. Go play catch with your boys. 
All right.

\section{SHARON}

I'll be in the kitchen. Whippin up my bomb ass lasagna.

Sharon exits to kitchen. Dale crosses to a coat rack by the front door and grabs his glove. He crosses toward Kal and Cobb.

\section{COBB}

Dad's really something, huh?

\section{KAL}

He's just a hot head. It's that competitive gene he's got. Makes him a little nuts. Lucky I don't have that gene.

$\mathrm{COBB}$

Yeah. But too bad you didn't get the good looks gene.

\section{KAL}

Shit. I'm all that and big ole bag of Funyons.

\section{COBB}

Believe what you want, little brother.

KAL

Oh I believe. (impersonating Donkey from Shrek) I believe, I believe, I believe, I believe, I believe ...

Dale comes downstage, glove in hand.

\section{DALE}

You all right there boy? Look like you're having a seizure.

Oh, Pop. Hey. What up?

KAL

Thought I might join you.

DALE

He holds up the glove.

Sure.

\section{KAL}


Heads up.

\section{Cobb throws the ball to Dale.}

\section{DALE}

Good throw. Keep your elbow out.

COBB

Sure.

Ahh Pop. Give it a rest.

KAL

DALE

You know I can't help it.

KAL

True. Very true.

DALE

So, Cobb. About earlier . . .

COBB

I shouldn't have surprised you like that.

DALE

Yeah.

COBB

I'm sorry.

DALE

It's alright.

COBB

And just to clear things up, all guys that go to prison don't develop homosexual relationships.

Uhh dude, what?

KAL

DALE

It was nothin. Just a conversation we were having.

Oh the whole sissy ...

KAL 


\title{
COBB
}

Yeah. Let's drop that subject, alright.

\author{
DALE
}

Done.

KAL

Whoa come on ... you get turned out or what?

DALE

Kal! Jesus. Your elbow, son.

KAL

Alright. Alright. (beat) Seriously, though, Cobb. What was it like in there?

Dale doesn't stop the inquiry. Cobb catches the ball and looks at it. He tosses it up in the air a couple of times.

COBB

You really want to know?

KAL

Yes.

COBB

Dad?

\section{DALE}

Wouldn't hurt knowing a little about what your life was like for the past few years.

\section{COBB}

Alright then. At first, it was pretty rough. Scary you know. It's not like you see in the movies or on TV though. The scariest thing is that you don't know anybody. You don't know your cell mate or who you are sitting by at chow or who you are smoking a cigarette next to.

You smoked?

DALE

COBB

Everybody smokes in prison.

DALE

Huh.

COBB 
Yeah. Haven't smoked one today, though. Don't even really want one. Anyway, so you don't know anybody. All you know is that everyone around you is a criminal of some kind. Really, they could be anything except the sex offenders - they are all in P. C.

P. C.?

KAL

Protective custody.

COBB

Sickos.

\section{KAL}

COBB

Yes. Yes they are. You haven't the slightest. We are actually lucky we have prisons. There are definitely a lot of people who belong there and not out in society.

\section{DALE}

I've known a few. Kal keep your goddamn elbow out.

KAL

Alright.

\section{DALE}

Guys I grew up with. They never had a shot. Would rather steal something than work for it any day. Don't care about whether they hurt other people or not. Think they deserve everything because they were given nothing.

\section{COBB}

Yeah. Dad. That's exactly right. In prison, that pretty much divides people. The inmates who mind their own business and everyone else who would just assume stomp your fucking face in for their own enjoyment. Most dudes just keep to themselves, but it only takes a few stompers to make a prison wing, or a chow hall, or the yard an uneasy place to be. I tell you what, I grew up quick. Learned really quickly that fear will kill you. It's like you used say about hitting a baseball, Dad: "you'll never hit unless you swing with confidence." I actually had that saying written on a piece of paper taped to the wall in my cell. My friends liked that saying.

No kidding?

DALE

Yeah.

COBB

Yeah.

You get in fights?

\section{KAL}




\section{COBB}

A few. Won some, lost some. But never backed down. Ended up in the hole a couple times, which is pretty rough.

The hole?

\section{KAL}

\section{COBB}

A cell by yourself, with nothing to do but stare at the ceiling. Time is definitely the enemy in the hole. It was never a big deal, though. The C.O.s knew I never started any of it. The hole was more of a formality. Overall, I got treated pretty good. Got into a routine and it actually went by pretty fast. Dad, you taught me about routines, you know practice routines?

That's right, Pop. You're all about routines.

\section{KAL}

Yeah. I guess I am.

\section{DALE}

KAL

So, Cobb. I wanted to ask you something?

COBB

Yeah.

KAL

It's about ... well ... it's about the night of the accident. I was talking to Marcy and she said that-

Kal throws the ball to Dale.

DALE

Kal! I said keep your goddamn elbow out!

KAL

What, Pop? It's not like I play anymore.

DALE

Another conversation for another time.

COBB

Dad.

KAL

(same time as Cobb's "Dad") I'm not playing. 


\section{DALE}

We'll see.

\section{COBB}

If he doesn't want to play, he doesn't want to play.

\section{DALE}

You stay the fuck out of this.

\section{KAL}

C'mon, Dad. Can't we just play catch?

\section{DALE}

I just don't get it! What the hell did I do to deserve this?! None of my sons have the courage, the determination to make it to the big leagues. It's a goddamn waste of time. You were all a goddamn waste of time!

Were?

\section{COBB}

KAL

Okay, then. It looks like cool Dad has left the building and Coach asshole is back. You bi-polar or something? You been drinking?

Dale throws the ball at Kal. It hits him in the gut. Kal bends over in pain.

\section{COBB}

Dad! What the fuck!

Cobb runs to Kal. Dale crosses and stands over them.

\section{DALE}

I'm sick of your smart-ass mouth, running all the goddamn time.

\section{Dad!!! Jesus.}

COBB

Screw you, old man.

\section{KAL}

DALE

Go to hell you little leach!

COBB

\section{That's it.}


Cobb has had enough. He steps to his father.

DALE

What are you gonna do, boy?

COBB

You are not our coach.

Cobb punches Dale in the gut.

You're our father.

\section{COBB (CONT'D)}

DALE

You son of a bitch!

Dale charges at Cobb, but Cobb handily throws him to the ground.

Dad. Stop.

KAL

COBB

You're pathetic.

Dale gets up and brushes himself off. He's ready for more.

DALE

That all you got, boy?

COBB

Come on, Dad.

KAL

Yeah, Pop. Calm down. What the hell is wrong with you?

\section{DALE}

Waste. Waste of talent. Waste of life!

Dale takes off toward Cobb. Kal grabs Dale from behind and stops him.

Get off me!

\section{DALE (CONT'D)}

KAL

Dad! 
C'mon Dad! Enough!

COBB

Sharon appears.

\section{SHARON}

Hey!!! What the hell is going on out there!?

They all pause and look at each other.

Nothing, Sharon. It's nothing.

DALE

Yeah, Mom. Nothin.

KAL

Kal lets go of Dale.

Yeah, Mom. It's nothing.

COBB

\section{SHARON}

Okay, then. Well it's time to come in. Dinner's almost ready and Marcy is on her way.

DALE

Alright, Sharon. One minute.

\section{SHARON}

Don't be long.

DALE

We won't. One. This never happened. Two. After dinner, Cobb, you leave. You're no longer welcome here.

Oh. Come on, Dad.

KAL

COBB

Fine.

DALE

Kal, you'll be gone soon enough.

Dad.

KAL 


\section{DALE}

You boys are too Goddam complicated. Why can't you be simple. Like ...

\section{COBB}

Baseball?

DALE

Yes. Like Baseball.

\section{COBB}

Baseball's not simple, Dad.

DALE

Yes it is. Go out and win. Pretty simple.

Dale walks toward the house.

Dad.

KAL

DALE

After dinner. Gone.

Dad.

KAL

Dale turns around.

KAL (CONT'D)

Catch.

Kal throws the ball.

DALE

Keep your elbow out, son.

Lights fade.

Black out.

Scene Three

Time: Present

The living room. 
J.D. bursts through the front door. He is off-kilter, inebriated. He still wears his baseball uniform, but it is now torn, almost shredded. He stumbles and the next lines are delivered at an annoyingly loud volume with a drunken slur.

J.D.

Ten thousand eyes were on him as he rubbed his hands with dirt!

Five thousand tongues applauded when he wiped them on his shirt!

Then while the writhing pitcher ground the ball into his hip,

Defiance flashed in Casey's eye, a sneer curled Casey's lip!

J.D. Sits on the living room couch. Out of a pocket he pulls out a case. It is his kit for shooting heroin. He calms and slowly recites the next lines of the poem, while we watch him shoot up.

From the benches, black with people, there went up a muffled roar, Like the beating of the storm-waves on a stern and distant shore;

"Kill him! Kill the umpire!" shouted someone on the stand;

And it's likely they'd have killed him had not Casey raised his hand.

He allows the drug to wash over him and sinks into the couch. As this happens, Sharon enters from the kitchen with a pan a lasagna and places it on the table. She looks around the table.

\section{SHARON}

Me. Cobb. Dale. Kal. Marcy. And Juana. Juana. Unbelievable.

She crosses back toward the kitchen then stops. She looks back at the table. She looks past the sofa where J.D. is sitting as if she senses something there. She then looks toward the sky.

\section{SHARON (CONT'D)}

I really wish you were here for this J.D. I really do.

She exits. J.D. comes to just enough to say the following.

J.D.

I do too, Mom. I do too. Go on and eat without me.

Lights fade.

Blackout.

Scene Four

Time: Four years ago. 
Place: At the bar.

Cobb sits at the bar in silence. A few moments pass. He picks up his phone and looks at it. He puts it in his pocket. Another moment passes.

\section{COBB}

What's that? No thanks. Sobering up a little before I go. Looks like my bro is no show. (beat) Is the game over? It is? Who won? I see. That's good, I guess. Must've bet on the Cubs, huh, little brother. (beat) I'll go ahead and settle up.

Cobb pull his wallet out and throws a credit card on the bar. Just then, J.D. bursts in, much like he did in the previous scene, inebriated and loud.

J.D.

Not so fast! We got some drinking to do!

COBB

Where the fuck have you been?

\section{J.D.}

Oh my brother. What a glorious day it is. Just glorious.

\section{COBB}

I take it you bet on the Cubs.

J.D.

To win and the over. Parlay, parlay, parlay. God I love that word. Parlay!

\section{COBB}

So, I've been waiting here all this time for nothing.

J.D.

Not nothing big brother. To celebrate! Bartender. Two tequilas.

How much you win?

COBB

J.D.

A good gambler never reveals the amount of his winnings.

Enough, I guess?

COBB

J.D.

Oh yes. More than enough. 
Good. Cause I'm low on funds as it is.

J.D.

You? Money bags? Well. No worries. I'll buy!

COBB

I don't think so, J.D. I drank enough waiting for you. I need to get going.

J.D.

Hold on a second! I've got something to tell you.

$\mathrm{COBB}$

What?

J.D.

It's a secret. Come closer.

COBB

Fuck you. Get away from me.

J.D.

Okay, then. (beat) THE OUTLOOK WASN'T BRILLIANT FOR THE MUDVILLE NINE THAT DAY!

COBB

(Overlapping)

Not again.

J.D.

THE SCORE STOOD FOUR TO TWO WITH BUT ONE INNING MORE TO PLAY!

COBB

(Overlapping)

Yeah, this his him. The guy I said would be famous one day.

J.D.

Oh you know I will. AND THEN WHEN COONEY DIED AT FIRST, AND

BARROWS DID THE SAME. A PALL-LIKE SILENCE FELL UPON THE PATRONS

OF THE GAME!

\section{COBB}

(Overlapping)

Yeah, yeah. A pall-like silence fell upon the patrons of the game. Will you shut up?!! I'll have one drink with you. One. 
J.D.

That's my boy! Just give me a second. I'm 'onna take a piss.

COBB

Alright. Just hurry up. Arianne is waiting for me.

J.D.

Oh. She's hot. Did I ever tell you how hot I think your girlfriend is? She is smoking!

Hold on to that one.

I'm doing my best.

\section{COBB}

J.D.

I'm 'onna drain the main vein. Then when I get back you tell me how she looks naked.

Sounds like a plan? Good. Great. Grand. Super.

COBB

Just go piss.

J.D.

Righty - Oh, Boy- Oh.

J.D. begins to exit. While he exits he continues his recitation of Casey at the Bat.

J.D. (CONT'D)

A straggling few got up to go in deep despair. The rest

Clung to the hope which springs eternal in the human breast;

They thought, "If only Casey could but get a whack at that

We'd put up even money now, with Casey at the bat."

COBB

God help me.

A few moments pass.

\section{COBB (CONT'D)}

Another Bombay, I guess.

The lights fade.

Blackout

Scene Five

Time: Present 
Place: The living Room.

Dale, Kal and Juana sit at the dinner table. There are mountains of food on the table.

\author{
KAL \\ (calling out)
}

Looks fan-fricking-tastic Mom! What do you think babe?

\title{
JUANA
}

Ay Dios Mio. I don't think I've ever seen this much food in my life.

\section{DALE}

So, Juana, are you bilingual?

JUANA

Not really. I just know a few words. But I really try to stay in touch with my Hispanic heritage.

Really? How so?

DALE

JUANA

Well. I eat at a lot of Mexican Restaurants. Taco Bell mostly.

DALE

I see.

Like I said, Juana's Mom doesn't cook much.

KAL

DALE

That so? What about your father?

JUANA

Muerte.

Excuse me?

DALE

JUANA

Mweeerrrrtttaaaaaay.

DALE

I'm sorry, I don't . . . 
He's dead. Muerte.

\section{JUANA}

DALE

Oh. I'm sorry to hear that.

No biggie.

JUANA

Sharon and Cobb enter. Sharon has a pitcher of water and Cobb carries a basket of rolls.

No Marcy yet, huh?

\section{SHARON}

KAL

Not yet.

Who's Marcy again?

JUANA

KAL

My sister. I told you.

JUANA

Marcy, huh? Is that a baseball player's name too?

No.

KAL

JUANA

Kal said you named all your kids after baseball players. Like famous baseball players. Is that true?

Sharon sits.

\section{SHARON}

Yes it is, Juana. Or should I call you Jane?

JUANA

Oh no. Me llamo Juana, por favor.

As you wish.

\section{SHARON}

JUANA 
Which players?

KAL

I told you this. I'm named after Kal Ripken, Sr. Not Junior, but senior.

There's two of them?

$$
\text { JUANA }
$$

COBB

Yes. A father and son.

DALE

Both hella good ballplayers. But Jr. was just amassing his legendary stats when Kal was named.

\section{KAL}

Yeah. Technically my name is spelled with a C, but I spell it with a K.

\section{DALE}

Never understood that one.

\section{COBB}

And I'm named after probably the greatest ball player who ever lived, Ty Cobb. But I've always gone by Cobb.

\section{DALE}

Yep. Greatest ball player that ever walked the earth.

What made him the best?

$$
\text { JUANA }
$$

\section{DALE}

Cause he had everything. The total package. Speed. Power. A rocket launcher of an arm. But most of all, he had a baseball player's attitude. Nothing kept him off the field.

Nothing.

COBB

Except his penchant for booze, women and cigars.

DALE

Yeah. Everything but those things.

JUANA

And what about your other brother? The dead one. Who's he named after?

\section{KAL}


Juana.

Just asking.

JUANA

DALE

He was named after Joe Dimaggio. The second greatest ball player who ever lived.

JUANA

Oh.

\section{COBB}

He ended up being the best ball player in the family, though.

SHARON

And I got to name our daughter. Dale and I made a deal when we got married. Dale could name the boys and I'd name the girls. Only had one daughter. And I named her Marcy. After my Grandmother.

\section{JUANA}

Is it true you adopted Kal because he was black and you'd thought he be a good athlete?

\section{SHARON}

Okay, Juana, I think that's enough with the questions.

That's what Kal said.

JUANA

Juana. Jesus.

KAL

DALE

Is that what Kal said?

JUANA

Yep.

Juana!

KAL

JUANA

What? You're the one who said it.

KAL

I never said . . . 


\section{DALE}

Would you like to know how we came to adopt Kal here?

\section{JUANA}

I would.

DALE

Well we...

\section{SHARON}

I'll tell it.

\section{DALE}

Good.

\section{SHARON}

Well. Dale used to coach a young man named Harrison. When Harrison was in -

Was he black?

$$
\text { JUANA }
$$

\section{SHARON}

Who?

JUANA

Harrison.

\section{SHARON}

Yes. Don't interrupt. It's not polite.

\section{JUANA}

Oh. Sorry.

\section{SHARON}

It's okay. Just . . okay . . . where was I?

\section{JUANA}

Harrison. You were talking about some black guy named Harrison.

\section{SHARON}

Yes. Thank you, Juana. Well. Like I was saying, Dale was coaching Harrison. It was Harrison's senior year in high school and he happened to get his girlfriend pregnant.

Harrison was looking at getting a scholarship ...

\section{DALE}

... or a major-league contract ... 


\section{SHARON}

Yes. He was trying to decide between going to college or signing a contract when he found out Gabriella...

Who's Gabriella?

JUANA

SHARON

Juana! Please.

KAL

She's my real Mom. She's messed up.

JUANA

Oh.

\section{SHARON}

Yes. His biological mother. Anyway, Gabriella was pregnant with little Kal here and Harrison was the father. Dale and Harrison were very close and Harrison was worried that taking care of a baby was going to make it hard to pursue his baseball career.

DALE

He was right.

\section{SHARON}

Dale.

DALE

Sharon.

\section{SHARON}

Anyway, Harrison and Gabriella decided they wanted to put their baby up for adoption. Well, it just so happened that I was unable to have any more children, so -

JUANA

Why?

SHARON

Another conversation for another time, Juana.

Oh. Okay.

JUANA

\section{SHARON}

So, Dale and I offered to adopt Kal. 


\section{KAL}

Harrison's family, they were poor, they were all banking on him making it in the big leagues.

\section{SHARON}

Yes. When they decided they for sure wanted to put Kal up for adoption, Dale and I decided we would do it and we'd let Harrison know how he was doing.

\section{KAL}

Yeah. He saw me a lot when I was little, then he didn't quite cut it in the majors. He works at a car dealership now.

\section{SHARON}

Yes.

JUANA

Why don't you live with him?

\section{KAL}

Because I chose not to.

JUANA

What about your real Mom?

\section{KAL}

I never even met her. She disappeared. My Dad let me decide where I wanted to live, and I decided to stay here.

He chose us.

\section{COBB}

\section{SHARON}

Yes, he did.

Wow, Kal. Todos Loco.

JUANA

It's okay. Things turned out alright.

\section{KAL}

JUANA

(to $\mathrm{Cobb})$

Didn't you kill people while driving drunk?

\section{COBB}

I, uhhh . . . 


\section{SHARON}

OKAY! Enough with the questions, Juana! Why don't' we eat?

Just then Marcy barges in the door. She is out of breath and frustrated. She is a force of nature. She speaks very quickly and a little too loud. Stillness comes over everyone at the table as they watch in awe the display that is Marcy.

\section{MARCY}

Motherfucker! There's a reason I don't come home very often. The traffic getting here is God awful! This guy cut me off and I flipped him off and he acted like he was going to get out of the car and kick my ass or something. I was like, "Bring it on! Motherfucker!" But he just drove off and nothing happened. Then I swear I hit almost every light in Naperville. I been here like five minutes and I already miss the city. (She breaths) So Hi, how is everybody!? Already eating huh? What's up big brother? Finally out of prison, huh? What are you waiting for, you going to get up and give me a hug or what?

Of course.

\section{COBB}

Cobb stands and moves out from the table.

Marcy runs to him and embraces him as hard as she possibly can. Cobb hugs her tightly.

It's okay sis.'

\section{COBB (CONT'D)}

\section{MARCY}

It finally is.

She keeps hugging him. She doesn't want to let go.

Hi Marcy.

\section{SHARON}

\section{MARCY}

Hi Mom. Hi Dad. Hi Kal. Hi, little girl that I don't know.

This is Juana, my girlfriend.

\section{KAL}

This causes Marcy to instantly let go of Cobb.

Girlfriend, huh?

\section{MARCY}


Yeah.

KAL

DALE

Yeah. Careful. Juana likes to ask questions.

MARCY

(to Juana)

Funny. I do to. What's your name?

Me llamo, Juana.

JUANA

MARCY

Nuh-huh. In English, hunny!

JUANA

Okay.

MARCY

Your name?

JUANA

Juana. I mean Jane if you want.

MARCY

Last name.

JUANA

Branch.

MARCY

GPA?

JUANA

Excuse me.

MARCY

GPA? Are you a good student? GPA?

Three point eight.

JUANA

MARCY

Play sports? 
No.

JUANA

Do drugs?

\section{MARCY}

JUANA

What? No.

\section{MARCY}

Practice safe sex?

\section{KAL/SHARON}

Marcy!

\section{MARCY}

What? I wanna know if she's a good girl or one of those slutbags like I used to know in high school.

\section{COBB}

Used to know? Used to be is more like it.

\section{MARCY}

Uh huh ho! Brother Cobb is back. Love it. Jane. I approve. Let's eat.

Everyone sits at the table and starts to eat. The lights dim a bit and J.D. enters. He walks around them, as they continue to eat and talk silently.

\section{J.D.}

That's my family. That's what I gave up. See that chair right there? The one that Juana or Jane or whatever is sitting in? That would be my chair. Instead, she's in it. Not me.

As he walks around the table he begins to recite the rest of Casey at the Bat. The following is intercut with dialogue from people at the table.

\section{J.D. (CONT'D)}

"Fraud!" cried the maddened thousands, and echo answered

"Fraud!" But one scornful look from Casey and the audience was awed.

\section{MARCY}

Cobb. I know this probably isn't the time to talk to about it, but I figured Kal haas been too scared to ask you, so I'm going to.

Go ahead.

\section{COBB}


What happened the night of the accident?

MARCY

COBB

Excuse me.

\section{MARCY}

What happened the night of the accident? We all know something happened? The cops said in the investigation that a bartender saw you and J.D. drinking at his bar like fifteen minutes before the accident.

J.D.

They saw his face grow stern and cold, they saw his muscles strain, And they knew that Casey wouldn't let that ball go by again.

I'm not sure what you mean?

\section{COBB}

MARCY

Oh, come on, Cobb.

COBB

I seriously have no idea what you are talking about.

You're lying.

\section{MARCY}

\section{KAL}

Yeah, Cobb. You're lying. That's why I came to visit you because Marcy told about this little tidbit of info. Funny thing is, you never said anything about seeing J.D. that night. Through the whole ordeal. And J.D. never said anything about seeing you that night either.

\section{SHARON}

I don't understand. What's this all about?

J.D.

The sneer is gone from Casey's lip, his teeth are clenched in hate, He pounds with cruel violence his bat upon the plate;

And now the pitcher holds the ball, and now he lets it go, And now the air is shattered by the force of Casey's blow.

Did you know about this, Dale?

\section{SHARON}

DALE 
No idea. What are they talking about, Cobb?

I seriously don't know. I swear.

$\mathrm{COBB}$

\section{MARCY}

Bullshit! I have a friend who's a lawyer and she said she worked on the case and when they were investigating it they found a bartender that swore you and J.D. were drinking in the same bar the night you killed those people. Is that true?

I don't . . . I can't ...

COBB

What is she saying Cobb?

\section{SHARON}

COBB

I don't know. I should go.

He begins to rise.

\section{DALE}

\section{SIT DOWN!}

\section{J.D.}

Oh, somewhere in this favoured land the sun is shining bright, The band is playing somewhere, and somewhere hearts are light;

What in the hell is she talking about?

\section{DALE}

\section{MARCY}

All I know is that my brother went to prison and soon after my other brother fell apart to the extent that he ended up overdosing on heroin. Something had to have happened? What was it?

\section{DALE}

What was it?

\section{SHARON}

Cobb.

\section{KAL}

Come on, Cobb. Tell us the truth.

\section{SHARON}


We deserve that much.

Alright. Alright.

COBB

\section{SHARON}

What is it, Cobb? Please. If you have answers, please tell us.

COBB

Alright. You knew about the gambling, right?

Gambling?

\section{SHARON}

COBB

Yes, J.D. was a compulsive gambler. You knew that, right? He sucked at hiding it.

SHARON

Dale?

DALE

Yes. I knew, I just ...

\section{SHARON}

You knew!?

DALE

I never thought it was that big of deal. What? Is that why he was so messed up?

COBB

No. No. No. Wait. It was . . that night . . it was . . he had won a bet and he . . I just . . . I thought if I took the rap, he would be the ball player you always wanted Dad. I thought ... I thought ...

\section{SHARON}

Oh my God. No.

DALE

Then it was.

What was?

\section{COBB}

\section{DALE}

It was my fault. It was all my fault. 
A long pause.

J.D

And somewhere men are laughing, and somewhere children shout,

But there is no joy in Mudville - mighty Casey has struck out.

Lights fade down. Lights up bar. J.D. and Cobb cross and sit at the bar. The rest of the family looks on. J.D. and Cobb transform into their drunken selves.

J.D.

Well! I have cut the root! The vein is drained!

$\mathrm{COBB}$

Shot?

J.D.

Sure.

They take the shots.

J.D. (CONT'D)

I got an idea. Let's get out of here. Let's go see Pop.

What? No way.

COBB

J.D.

Let's go throw the ball around then.

COBB

I could do that.

J.D.

I'll drive.

COBB

Where's your car?

J.D.

Had to create some revenue for that bet.

You sold your fucking car?

COBB

J.D.

Yep. 


\section{COBB}

Jesus.

J.D.

You got gloves and a ball?

COBB

In the trunk.

J.D.

Good.

$\mathrm{COBB}$

I gotta pay.

J.D.

Let me get that.

J.D. pulls out a wad of cash, pulls a hundred-dollar bill from the roll and slams it on the bar.

J.D. (CONT'D)

That's how it's done, big brother.

COBB

That so?

J.D.

Yep. Let's go.

COBB

After you.

J.D.

Alright. But I'm driving!

COBB

Fine by me.

Cobb tosses J.D. his keys.

J.D.

Earlier today, they clocked me at ninety-four with my fastball.

\section{COBB}

You're kidding? That's major league speed. 
J.D.

That's what Pop said. Wonder if your car can hit ninety-four?

\section{COBB}

Not sure that's a good idea.

J.D.

Oh, my brother. You do sound like Dad.

J.D. exits. Cobb watches his little brother for a second. He smiles then follows him out.

Lights down.

End of play. 


\section{Chapter 4: The Disappointments}

Introduction

The Disappointments is the most personal play I have ever written. Second's journey in the play is very much like my own. I knew at some point I would write a play about my experience in treatment; however, at the time I decided to write the play as part of this project, it was difficult to picture the play in my mind. Ideas for plays usually come to me in images. I will see, in my mind's eye, scenes happening and a story forming, playing itself out in my imagination. For The Disappointments, I struggled to picture anything.

The Disappointments was originally called Mike and Zach Go to Rehab! My first inclination was to write a straight comedy about treatment based on two people, Mike and Zach, who, while I was in rehab with them, would continually make me laugh. However, as I thought more and more about it, I knew the play could not be that - it could not be all comedy because treatment is inherently tragic. Two words kept ringing in my head from my time in treatment: tragic and funny. In treatment, we do cry - a lotbut we laugh more. I wanted to try and capture that truth in my text. That was the first thing I knew I had to do.

The first scene of the play I based on the day my fiancé showed up at my house with my mother to confront me about my drinking. I was passed out in my bed when I heard knocking at my door. Much like it is written in the play, I remember the sound of the knock penetrating my mind until I woke up. When I opened my front door my fiancé and mother were standing there. The first thing I said, which became Second's first line of the play, was “Ahhh, shit." At that moment, I knew what needed to happen-I knew I 
needed to go to treatment. However, when I wrote the first twenty pages of the play, I did not include that scene. It was not until after the first reading that I decided I should add it in.

We had a reading of the first twenty pages and Dr. David White, a professor of theatre and accomplished playwright, happened to be there. We started talking and I told him the play is autobiographical and he said he wanted to know why Second decided, on that day, to go to a rehabilitation center - that there needed to be an impetus or altercation that drives him. I told him about the day my mother and fiancé showed up at my house and I went to treatment. He exclaimed, "Yes! Write that!" So, I did. My fiancé, who is now my wife, also had asked me when I was going to include her in a play and so I figured this would be a good chance, though I am not sure this is what she had in mind.

I knew the play was going to be inspired by my own journey, but I knew also that it needed to be dramatized. To do this, I had to make certain decisions; most importantly, who were the characters I was going to include? This was difficult for many reasons. I really did not want to do an all-male treatment facility. Most treatment centers are co-ed. At first, I developed both female and male characters, but the character list was just too many and I was left to make perhaps the most difficult choice of writing this play; to focus on men in rehab instead of both men and women.

One of the reasons I wanted to keep the patients the same gender was to keep the set simple. The reason I want to keep the set simple is because I want to keep production costs low, so producers will be more likely to produce the play. I wanted to be able to represent the one room on stage where the characters would interact and much of the action would take place. No audience would buy into a world in which men and women 
would share the same room in a treatment center. Therefore, I settled on four roommates, all-male; but to counter this, I added a female med-tech and the fiancé. It was important to me that the counselor was male since the patients were male. I knew there would be violence and I did not want to get into the difficulties of writing violence between men and women on stage. Therefore, with the genders figured out, I set out to develop the characters.

Each character is specifically chosen to represent treatment like it is: a potpourri of characters that are completely different, but all relate to each other because they share the same disease. Originally, I specified the race of each character, but decided against that after some concerns were raised about the depiction of race in the play (more on that to come). In the play, there is Second who is educated, upper-middle class; Nifty who is uneducated, street-smart and tough; Luis (pronounced Lou-eez if played by a Latino actor) who is uneducated, lower-class and soft-spoken; Robert who is a middle-aged, middle-class country boy, a father and when sober an all-around good guy. These main characters became the representations of the common dynamic of people I encountered in treatment. People from completely different walks-of-life brought together for a common purpose: to attempt to recover from their alcoholism or addiction.

I originally wrote Nifty specifically as young African-American male. He was based on a couple of black men I was in treatment with in 2011. His language is directly inspired by the musicality of how they spoke. When I first workshopped the play one of the people at the reading, a white woman, took great offense to how I wrote the voice of the black character. Additionally, Luis was originally supposed to be Latino. The woman also took offense to the fact that the Latino character is the one that dies. After discussing 
her comments with a few people, I came to understand her complaints. Though I was writing what I felt to be my truth, I was not considering the truth of others. Therefore, I made the decision to take character-specific color out of the character descriptions and add a note that precedes the character descriptions which states:

Note: It is important this play is done with color-conscious casting. Treatment facilities consist of a diverse group of people as alcoholism and addiction does not discriminate. The playwright insists on a diverse cast. If this is not possible, the playwright would rather the play not be performed.

I was not sure leaving the color of the characters unspecified would work. So, I reread my play, allowing myself to envision the characters as different races. It worked. I felt like I did not need to change anything except for a few specific references. In last production of the play, which was a staged-reading, we had a diverse cast that was not like I originally intended. I think it was much better than my original vision.

Perhaps the most important character in The Disappointments is Patrick. Patrick is based on the actual Patrick, a counselor from my time at Valley Hope. He is smart, funny, well-educated and effective. I wanted the character of Patrick to embody those characteristics. I made a rule long ago that I would not give a character the same name as someone from real life, but this was different. Additionally, I liked the hard consonants in the name Patrick. I ran through hundreds of names trying to find something that I liked better, but nothing fit. So, I went with it.

Patrick is important because he is the voice of my truth about recovery. Previously in this dissertation, I stated twenty truths I have come to know about alcoholism and recovery. Patrick specifically addresses these throughout his scenes in the 
play. Perhaps the most important is the scene when he gets Second to realize his identity as an alcoholic. Additionally, Patrick also emphasizes the need for continual recovery. In the play, the characters state more than once to "go to meetings, get a sponsor, work the steps." In treatment, patients hear this mantra stated over and over. This is because it is what most believe works for those being released from treatment. Without those three things: going to meetings, getting a sponsor, and working the steps, the chances of an addict relapsing are very high. The chances are high, regardless. But, doing these three things_-getting a sponsor, going to meetings, working the steps_-guarantees continual attention to recovery and an alcoholic who is newly sober, if nothing else, needs a plan. That is all it is - a plan.

The play utilizes stage realism as its technique. This method was deliberately used to simplify the story for audiences. The intent of the play is to illuminate the intricacies, complications and inner-workings of an alcoholism and addiction treatment facility and the journey an alcoholic takes once they enter one. The play is not meant for what we usually deem the enlightened theatre-goer. Instead, it is meant for everyone (except children). I wanted to write a play for the masses about a subject unfamiliar to the masses.

The story has a clear, simple, traditional plot. It begins with a balance which is Second's usual drunken state but is soon followed by an inciting incident: his fiancé's ultimatum that she is going to leave him unless he goes to rehab. This sets the action in motion. Second then encounters crises and complications which lead to the climax of Patrick getting stabbed and Second realizing that fear is driving his alcoholism. After this realization, there is a denouement scene in which balance is restored: Second's fiancé has 
brought save-the-dates for their wedding to the treatment facility. This plot is purposefully easy to follow. It is Aristotelian in its Unity of Action - there is one central plot, one dramatic through line. ${ }^{49}$

Due to the simple nature of the play's plot, I knew I needed to make the characters complex. Since this play is semi-autobiographical in nature, the protagonist of the story is based on myself. His fiancé is based on my fiancé and, as previously stated, the opening scene is based on the actual events that took place. This may seem a tad arrogant, but I found myself to be unique in the treatment facility. My education level was the thing that most differentiated me from the other patients. They seemed surprised that a college graduate working on his Ph.D. would be in treatment. Some of them even nicknamed me "professor." For this play, I wanted to tell my own story as opposed to creating a character with which I was not familiar. I felt this was how I could be the most truthful. I could inject my truth into the script without doubt.

As previously mentioned, I have a journal of my time spent in prison/rehab in 2011. In this journal, I have descriptions of some of the oddest and most fascinating people I have ever met. The character that came from my 2011 stint in rehab was Nifty. This is due to the language that he used. It was a biting, energetic, street-smart language that I found exciting. This guy, as I got to know him, had a way of always externalizing confidence; however, deep down there was a real sadness to him. This was important to include because it personifies the notion of being "a disappointment." He truly felt like he disappointed everyone in his life; there were not many people that truly cared about him, if any. At times this sadness and frustration would manifest itself in lashing out and

49 Jeffrey Hatcher, The Art and Craft of Playwriting (Cincinnati: Story Press, 1996), 35 
trying to start fights. I have always been impressed by individuals who will "step to" or confront another person without any hesitation. They seem to have no fear of consequences and, to me, that makes for a fascinating character.

Nifty represents the type of person one may find in a treatment center who rarely lets his or her guard down, but when he or she does, underneath is a lot of pain. He/she cannot find truth because the disappointment with how his/her life turned out is just too much for the person to handle. However, recovery does work and sometimes people like Nifty do find it; and sometimes, like in the play, he/she turns back to alcohol or drugs to make the pain go away.

The other character I drew from my journal is Zach, the "guy that sucks." My cell-mate during part of my prison stay was a guy that sucked. I could empathize with him because that is how I am, but he was the type of guy that would shake my hand one second and rob me the next without a hint of remorse-which he did. There are a lot of good people in rehabilitation, however, there are people that do not have good intentions. It was important to include this character type because it is the truth. The benefit of this character as it pertains to dramatic form is that it allows me to include a villain to further the action.

Robert is a combination of two guys I met in Valley Hope. Like I stated earlier, The Disappointments was originally called Mike and Zach go to Rehab! Mike and Zach are two very likeable country boys, but both, at the time, were dealing with some heavy stuff. Though I decided not to write Mike and Zach go to Rehab!; I did not want to cut them out, so the two of them combined to become Robert. Robert's character is vital to the truth of this play. In thinking about the alcoholic's relationship to alcohol, Robert 
embodies the alcoholic who takes on a personality very unlike their own when they drink. After the audience meets and gets to know the character as a nice guy, he tells the story of when he hit his young son. This recollection of violence is surprising, but, sadly, not that abnormal in an active alcoholic. This provides the audience insight into the dichotomy of the personality of an active alcoholic versus a recovering alcoholic.

Luis was also inspired by someone from Valley Hope. He was not the smartest person I ever met but had a good heart and the best intentions. While at Valley Hope, I heard that a previous patient had overdosed and died. I placed that story with the character of Luis and his part in the story of The Disappointments. Luis exemplifies the tragedy of alcoholism and recovery. Luis seems like he is determined to stay in recovery, but soon after leaving treatment, he relapses and subsequently dies from the relapse. This is also a truth about recovery that I could not overlook - no matter how hard someone might try, and no matter how determined he/she may be, sometimes the addiction just wins.

Charlotte is based one of the med-techs from Valley Hope. She was very motherly. She was a recovering addict who had been through Valley Hope herself and came back to work there. I never knew her full-story, but she was a very caring person with a delightful personality. And she called everybody "hunny." Treatment centers would not run without people like Charlotte. They do not make much money, but they are completely devoted to their job and fully believe in what they do. Many of the people that choose to work in alcoholism and addiction rehabilitation are in recovery. As Charlotte states in the play, she helps other people to recover because it helps her own recovery.

Each of these characters inform the plot in some way. Additionally, they also all 
have a great impact on Second, the protagonist. Through his relationships with the others, he recognizes his own alcoholism. About halfway through the play, his identity shifts as he realizes he is an alcoholic and is like the other patients at the treatment center. They are no longer the "other" because he has become the "other." It is only when Second becomes one of The Disappointments, that he can then recover.

Because the characters are so integral to the strength of the play, I found it necessary to give them each a moment to share part of their story. To do this, I decided that each character would break the fourth wall and tell the audience part of their storysomething in their background that has brought them to this point. This technique is influenced by Bertolt Brecht's Epic Theatre. Brecht wrote plays intended to change the world. One of the techniques he used in Epic Theatre was direct address to the audience. This technique makes the audience slightly uncomfortable because the actor is looking directly at them. It is this discomfort, Brecht surmised, that provokes the audience to take action. Additionally, this was a way to once again utilize recovery narratives to enhance the effectiveness of drama. Through these monologues the audience could understand each character better and thus further empathize with them.

The Disappointments was recently performed as a stage-reading for the 2018 Mizzou New Play Series. It received a very positive response. Some of the notable comments were that it was "engaging throughout," "I learned a lot about rehab which I knew nothing about" and, most importantly for me, Patrick, the actual counselor from Valley Hope, was in the audience and told me "he was incredibly moved." He added that at one point, he wept. That was all I needed to know I had written the play I set out to write. 
This play could be produced in almost any space, with a minimal set. My goal is to get this play out in front of as many audiences as possible. I do not believe this play is going to be a Broadway hit, nor is it written for the purpose of pleasing mass audiences. I envision this play being staged in gymnasiums, conference rooms and black box theatres. More than anything, I want people struggling with alcoholism and/or addiction, people in recovery, and recovery families to see the play. I believe they would benefit from the experience. 


\section{The Disappointments: A Play}

By Aaron Michael Scully

Aaron Michael Scully

508 Fountain Hills Dr.

Warrensburg, MO 64093

aaronscully76@gmail.com 660-924-6304 


\section{Characters}

Note: It is important this play is done with color-conscious casting. Treatment facilities consist of a diverse group of people as alcoholism and addiction does not discriminate. The playwright insists on a diverse cast. If this is not possible, the playwright would rather the play not be performed.

Second - mid-twenties- alcoholic

Erica - early-twenties - Second's fiancé

Nifty - early-twenties - opiate addict

Robert - forty-four - alcoholic

Luis (or Lewis) - nineteen - heroin addict

Charlotte - Med Tech - fifties - recovering addict

Patrick - Drug and Alcohol Counselor - forties - recovering addict

Zach - twenties - addict

Location

Second's Apartment and The Good House

Time

Present

// denotes the start of the next line of dialogue 


\section{Inside Second's Home.}

SECOND sits in the chair, slumped over, passed out. A liquor bottle is on the floor close to him.

A KNOCK. Another knock. The knocks should be quiet at first, but then grow louder and louder as the sound begins to penetrate Second's mind. Underneath the knock we hear Erica from offstage.

\section{ERICA}

$$
\text { (off) }
$$

Second! Open the door. C'mon baby. Open the door. Open the door, or I'm calling 9-1-1! Second! C'mon! Answer the door!

The knocks and shouts continue. Second stirs and finally gets up. He stumbles offstage.

\section{SECOND}

(off)

Ahhh, shit.

\section{ERICA}

(off)

What are you ... Oh my God.

Second stumbles back to sit. Erica follows him.

\section{ERICA (CONT)}

Sec.

\section{SECOND}

I'm fine. Just let me sleep and I'll be fine.

\section{ERICA}

That's what you said yesterday.

What?

\section{SECOND}

\section{ERICA}

You said that yesterday.

\section{SECOND}

\section{I did?}




\section{ERICA}

Do you not remember yesterday?

\section{SECOND}

No. No. I remember. I just. I must of. I'm sorry.

\section{ERICA}

You have to get help.

\section{SECOND}

(forceful)

No.

\section{ERICA}

Why not?

\section{SECOND}

I'll be fine. It'll be fine. Just Jim- fucking-dandy it will be babe! Just need some sleep and that'll be all that I need.

I don't understand.

\section{ERICA}

What?

\section{SECOND}

\section{ERICA}

I'm not going on like this. I'm not going to marry a drunk. Either you do something, or I'm done.

An ultimatum, huh?

\section{SECOND}

\section{ERICA}

Yes.

\section{SECOND}

You sure this is the way you want to play this?

\section{ERICA}

You're leaving me no choice.

\section{SECOND}

You know what? Get the fuck out!

\section{ERICA}


Second, don't.

GO!

No, please, Sec.

OUT!

SECOND

\author{
ERICA
}

SECOND

Erica smacks Second.

\title{
ERICA
}

I can't believe you are willing to throw us away.

Erica begins to exit.

\section{SECOND}

(quietly, but enough to get her to stop)

You don't get it.

\section{ERICA}

Help me understand.

\section{SECOND}

I can't . . I can't . . .

You can't what?

\section{ERICA}

\section{SECOND}

I can't ... stop.

\section{ERICA}

Why not?

\section{SECOND}

My body ... My mind screams at me to not to get more, but next thing I know my body takes over ... It's like I'm on autopilot or something.

Oh.

\section{ERICA}

\section{SECOND}

Yeah. 


\title{
ERICA
}

My sister, she told me about this place called The Good House. It's a treatment center. It's like thirty minutes from here.

Your sister?

\section{SECOND}

ERICA

Mike went there.

Really?

\section{SECOND}

\section{ERICA}

Almost ended their marriage.

SECOND

Oh.

ERICA

Should I call them?

\section{SECOND}

Who?

\author{
ERICA
}

The treatment center.

Oh. I guess.

\section{SECOND}

ERICA

Great.

The Good House?

SECOND

Yeah. The Good House.

\section{ERICA}

Erica pulls out her cell phone and crosses to the other side of the stage. Second steps forward.

SECOND

(to audience) 
Let's get something straight. No one ever wants to go rehab. It fucks everything up. Or at least it seems like it's going to fuck everything up. And for an alcoholic, by fucking everything up, it means that you are going to have to stop drinking. Stopping seems unimaginable. Impossible. It's like standing on the edge of a cliff. If you get too close, you might fall off. But if you retreat, move away from the edge, you just might be able to save yourself. The bad thing about a drunk, though, they refuse to recognize they are even standing near a cliff at all. Either that, or they have already fallen off and are falling and falling and falling just waiting for the ground to make it all stop.

\section{Erica hangs up the phone.}

\section{ERICA}

They have a bed open.

Really?

\section{SECOND}

ERICA

I can pack you a bag.

You want me to go right now?

\section{SECOND}

\section{ERICA}

Yes.

\section{SECOND}

I can't do that. What about work? I can't miss work.

\section{ERICA}

Actually, your boss called me. He doesn't want to fire you, but he will. He said to try and get you some help and he would cover for you. Said he'd give you one more chance.

One more, huh?

\section{SECOND}

\section{ERICA}

What he said.

\section{SECOND}

He doesn't bullshit.

\section{ERICA}

Nope. You have people that love you, Sec.

\section{SECOND}


I guess.

ERICA

Come on. To the bedroom. I'll help you pack.

Okay.

\section{SECOND}

Erica sees the bottle.

\section{ERICA}

Oh. Uhhh, the lady on the phone said you should keep drinking until you get there. They said they want to monitor you while you go through detoxification. I guess it's dangerous.

Really?

\section{SECOND}

\section{ERICA}

Weird, right.

Erica picks up the bottle and hands it to Second.

Here. Just a little.

\section{ERICA}

Sec takes the bottle. He stares at it but doesn't drink.

\section{SECOND}

I'm sorry.

\section{ERICA}

Don't be sorry. Just be better.

\section{SECOND}

Okay.

\section{ERICA}

I'll get your stuff.

Erica exits.

\section{SECOND}

(to audience)

See the thing about deciding to go to rehab, is that it sounds good for a little bit, and then real-quick-like, it doesn't. First you agree to go, but then you instantly regret it. For me, 
though, I know something has to give. My boss . . . it's strange that people won't just tell you to your face that they think you have a problem. So, I don't want to lose Erica and I don't want to get fired. Guess I better give this thing a shot. Before we go, though, it's only natural for one valiant last-ditch effort to get out of it. Here goes nothing. (to Erica) Hey. Erica. Are you sure this is a good idea? I mean, I'll be okay. I can stop. I'll like go to AA or something ...

No, Sec.

\section{ERICA}

\section{SECOND}

Alright. Alright. (back to audience) Shitballs.

Second exits.

\section{Outside of the The Good House.}

Second and Erica enter. Second is pulling a suitcase. Second is clearly more drunk than in the previous scene.

\section{SECOND}

So, this is it huh? The Good House.

This is it.

$$
\text { ERICA }
$$

\section{SECOND}

Wonder what's so good about it.

\section{ERICA}

Nice landscaping.

Can I please just go home?

\section{SECOND}

ERICA

Sec.

C'mon. Please.

\section{SECOND}

\section{ERICA}

No.

I'll be good. I promise.

\section{SECOND}


Second tries to hug Erica playfully. Erica pushes him away.

ERICA

If you stay, I won't leave.

Charlotte enters.

How ya'll doin?

CHARLOTTE

ERICA

Uhhh good. I'm Erica. This // is . . .

CHARLOTTE

You must be John?

ERICA/SECOND

Second.

(simultaneously)

Pardon?

CHARLOTTE

His name is John, but he goes by Second.

\title{
ERICA
}

\section{SECOND}

John Michael Silver, Junior. Second. At your service.

You must be Erica.

\author{
CHARLOTTE
}

ERICA

It's nice to meet you.

\section{CHARLOTTE}

We'll take good care of this guy.

\author{
ERICA
}

I hope so.

\section{CHARLOTTE}

We will. Okay, Second. You coming in?

SECOND

(To Erica) 
Am I?

ERICA

You are.

\section{SECOND}

I guess I am.

\section{ERICA}

Good.

CHARLOTTE

I have to ask, you got any booze or drugs on you?

Why? You want some?

SECOND

ERICA

Second.

CHARLOTTE

That's a good one, hunny. Never heard that before. But seriously, you can't bring any booze or drugs inside. Best if you have // any that . .

He doesn't do drugs.

\section{ERICA}

\section{CHARLOTTE}

Well that's good.

\section{SECOND}

She's right. No drugs. Probably shouldn't be here then, huh? Let's go.

\section{CHARLOTTE}

Only you know if you should be here, hunny. But I have a feeling you may be at the right place. So no drugs. How about booze? Flask or pint or anything? Airplane bottles?

Sec.

$$
\text { ERICA }
$$

\section{SECOND}

Erica.

ERICA

Se-ec. 


\section{SECOND}

Ericaaaaa.

ERICA

Just give it to her.

Give her what?

\section{SECOND}

\section{ERICA}

The pint.

\section{SECOND}

Huh.

\section{ERICA}

In your sock.

\section{SECOND}

What pint?

ERICA

C'mon Sec. I'm not an idiot.

\section{SECOND}

I don't have a pint in my sock. I mean who keeps a pint in their // fricking sock?

\section{ERICA}

He has a pint of vodka in his sock.

\section{SECOND}

(embarrassed)

No I don't.

\section{CHARLOTTE}

I tell you what. We'll make a deal. You take that pint out, you can take a drink right here, right now. You drink on the way here?

Before we left.

\section{ERICA}

\section{CHARLOTTE}

We do like our intoxicated patients to stay intoxicated until they get here. I know it seems unorthodox, but it's the safest way to do things.

\section{ERICA}


So weird. It' so weird.

I know, hunny.

CHARLOTTE

SECOND

Works for me.

\section{CHARLOTTE}

I can see that. So how about it? One last drink.

SECOND

Seriously?

Second looks at Erica.

\section{ERICA}

Don't ask me.

\section{SECOND}

This isn't a trick?

\section{CHARLOTTE}

No tricks, hunny. Only pedaling honesty around here.

\section{SECOND}

Okay, then.

Second pulls up his jeans and takes out a pint and twists the top off.

ERICA

One last one, okay? Ummm, I'm not gonna watch. I've seen you drink enough for this lifetime.

Erica turns away. Second takes a long look at the bottle.

\section{SECOND}

Last drink ever.

\section{CHARLOTTE}

That's the point.

He takes a long look at the bottle.

\section{SECOND}

Cheers. 
He takes a long swig.

Good.

\section{CHARLOTTE}

\section{Erica turns around.}

SECOND

(to Erica)

You okay?

\section{ERICA}

I will be if you will be.

\section{SECOND}

Okay. I guess this is it then.

\section{ERICA}

Yep. I love you, Second.

SECOND

You still want to marry me?

\section{ERICA}

Yes. Just ... do what you need to do to get better, okay?

Better go in.

\section{SECOND}

Right this way. I'll take that.

\section{CHARLOTTE}

Charlotte takes the bottle and dumps the rest.

Bye, babe.

\section{ERICA}

\section{SECOND}

(half-way looking at Erica, half-way watching the vodka pour onto the ground) Bye.

Call me tonight.

\section{ERICA}

\section{CHARLOTTE}

I'm sorry. But there's a five-day call rule. No calls out for the first five days. 


\section{SECOND}

What? That ain't cool. How // come I can't ...

ERICA

It's okay.

SECOND

This place better not be like prison.

\section{CHARLOTTE}

You've been to prison?

\section{SECOND}

County. For a night.

\section{CHARLOTTE}

Ha! Well, then that's a no. So you got nothing to compare it to, hunny.

\section{ERICA}

I love you.

\section{SECOND}

Love you too.

Second and Charlotte begin to exit. Erica stands and watches them leave.

\section{CHARLOTTE}

Anything else I should know about?

\section{SECOND}

Nope. Just that this should be no big deal. A few days and I'll be good.

Sure, hunny.

$$
\text { CHARLOTTE }
$$

\section{SECOND}

I'm a good guy.

CHARLOTTE

I'm sure you are, but in here everybody's the same.

I don't follow.

SECOND

CHARLOTTE 
Alcoholics. Addicts. Just a bunch of disappointments. At least that's what they think they are when they get here.

\section{SECOND}

Ya lost me.

\section{CHARLOTTE}

You've gotta a long way to go and a lot to learn, hunny. One step at a time.

They exit. Erica stands center stage. She addresses the audience.

\section{ERICA}

My Dad was an alcoholic. They say women are attracted to men that remind them of their fathers. I suppose I'm that. My Dad never got sober. But, he never really tried. If Sec wouldn't have checked in today, I would leave him. He really is a good guy. I know you're probably saying to yourself, "why would you even stay with him?" You think I should just run away. Well, you have to remember, I met Sec before you did. Long before you did. I know the REAL Sec. Sure, he liked to go out and he'd drink, but so did I. A few months ago, though, I noticed him changing. Hiding. Going out less and staying home more. We've been together for three years and I can tell when he's lying or if he's not telling me the whole truth. He was doing that a lot. For a little while, I let it go. I think I wanted to not know - like how we lie to ourselves when we don't want to believe something is true. I did that until I couldn't do it anymore. I'd surprise him at home, which he absolutely hated, and every time I did, he was really drunk. Well, let me tell you, there is no way I am staying in a relationship like that. I mean, I want to get married as much at the next girl, but I won't live like that. I hope he figures out something or, believe me, I will be leaving him. One chance. He's getting one chance. Or I will leave him. I will. I hope they can help him. They have to.

She exits. As she exits, Charlotte and Second enter.

\section{A Patient Room in The Good House.}

Lights up on room with four beds. In one bed is Robert, reading a book.

\section{CHARLOTTE}

Well. This is it. The medication we gave you will kick in soon and you'll want to be in bed.

Okay.

SECOND

How you doing today, Robert?

\section{CHARLOTTE}


Robert puts his book down, stands and crosses over to Second and shakes his hand.

Super-duper. You?

ROBERT

CHARLOTTE

Just fine, hunny. This is Second.

ROBERT

Second?

CHARLOTTE

It's short for Junior. Like John Jr.

ROBERT

Oh. Okay. Neat. How ya doing?

SECOND

Fine.

ROBERT

Ya look like I wanna feel.

SECOND

Which bed is mine?

\section{CHARLOTTE}

The second one. Ha! That'll be easy for you to remember. That's your trunk for your stuff. Robert, will you fill him in on the rest?

ROBERT

Sure.

CHARLOTTE

(to Second)

You gonna be okay, hunny?

SECOND

Yep.

\section{CHARLOTTE}

Alright Sweetie. If you need anything, just come to the patient station. We'll wake you in four hours to check your vitals, okay?

SECOND 
Sure.

\section{CHARLOTTE}

Get some rest, Sweetie. It's gonna be a rough few days, but you can do it. We'll do everything we can to keep you comfortable.

\section{SECOND}

This is gonna suck, huh?

\section{CHARLOTTE}

You'll be fine.

Charlotte exits. Second sits on the edge of the bed.

It's gonna suck.

\section{ROBERT}

\section{SECOND}

I know. I try like every day. Can't do it.

ROBERT

Mine was rough. Felt like slitting my fucking wrists.

That's comforting.

SECOND

ROBERT

No reason to sugar coat it.

SECOND

Guess not.

ROBERT

The Ativan 'll help. How long ago ya take it?

\section{SECOND}

Five minutes.

How many milligrams?

ROBERT

I don't know.

SECOND

\section{ROBERT}

One pill or two? 


\section{SECOND}

Just one.

What'd you blow?

\section{ROBERT}

Point two eight.

\section{SECOND}

ROBERT

Holy shit! You got me beat. Point one nine. You handle yourself well.

\section{SECOND}

Yeah. Not sure that's something to be proud of.

\section{ROBERT}

You'll be asleep soon. Probably won't start to withdraw for a few hours.

How long you been here?

\section{SECOND}

\section{ROBERT}

This is day four. Four days.

Where's everybody else?

\section{SECOND}

\section{ROBERT}

Group.

\section{SECOND}

Oh.

\section{ROBERT}

I'm technically still in detox, so I don't have to go. You been to rehab before?

Nope.

\section{SECOND}

\section{ROBERT}

Well, this is number three for me. This place ain't bad, except they don't have detox rooms. You just gotta do it in here, then you stay here. Different from other places I have been.

How's that?

\section{SECOND}




\section{ROBERT}

Other places have separate detox rooms. You move to another room after detox. If you come in sober, you don't have to stay in the same room with new patients.

\section{SECOND}

Oh.

\section{ROBERT}

But this place is alright. The Good House ain't too bad.

\section{SECOND}

Your wife make you come or something?

\section{ROBERT}

My wife took the kids and left long ago. A long story. And a boring one.

\section{SECOND}

Sorry.

\section{ROBERT}

No big deal. My story isn't half as bad as most of the people in here. Get some rest. We can talk later. Nifty and Luis are your other roommates. They don't ever shut the fuck up, so sleep while you can.

What if I want to leave?

\section{SECOND}

\section{ROBERT}

You can just leave. It's not prison. Hell, might as well give it a shot though. At least sober up. It's not gonna be pleasant, but it won't be near as bad as trying to do it at home on your own.

\section{Second lays back and stares at the ceiling.}

ROBERT

I'm hittin' the cafeteria. You need anything.

\section{SECOND}

Vodka soda. On the rocks with a lime.

\section{ROBERT}

Ha! Beer man, myself. Gatorade?

\section{SECOND}

I'm good. 


\section{ROBERT}

You'll be alright, pal. Just get some rest. See ya on the flipside.

\section{SECOND}

Yep.

Robert exits.

\section{SECOND}

(to audience)

I know I'm not showing it, but I'm . . . this sucks. This really fucking sucks. Sorry you have to watch this.

Second pulls the covers over him. After a moment he jolts up in bed, as if from a bad dream. He is in pain. He is in the throws of detox. He pulls his shirt off and throws it on the ground. He lays back, tosses and turns and then sits back up. He moves to the edge of the bed. He dry heaves.

Help me. Please help me.

\section{SECOND (CONT'D)}

Beat. Dry heave.

\section{SECOND (CONT'D)}

Hello? Anybody? Is anybody there?

Second tries to stand and walk but can't. He falls to the floor clutching his stomach.

\section{SECOND (CONT'D) \\ (desperate)}

Oh my God. Oh my God. Oh my God. I can't do this.

We hear the voices of Nifty and Luis from offstage as they enter.

NIFTY

(entering somewhere during this line)

So, I say, get back or I'm gonna stick one of these chopsticks in your eye and the other in your punk ass.

No way.

\section{LUIS}

NIFTY

I couldn't make this shit up if I tried. 
They see Second on the ground.

NIFTY (CONT'D)

Hey, you okay? (To Luis) Get Charlotte.

Luis runs out. Nifty crosses to Second.

NIFTY (CONT'D)

Can you get up man?

\author{
SECOND
}

I can't.

NIFTY

Yes you can.

Second dry heaves wildly.

Charlotte! Hurry up!

NIFTY (CONT'D)

Beat.

NIFTY (CONT'D)

Charlotte's coming. She'll give you something to knock your ass out.

It fucking hurts.

\title{
SECOND
}

NIFTY

I know man. You should try opiate withdrawals. They are like being thrown into a tornado full of knives.

I'm gonna shit my pants.

\section{SECOND}

NIFTY

What? No way, man. CHARLOTTE!! C'mon get up. I'll get you to the bathroom.

SECOND

Okay.

Nifty picks Second up and puts his arm over his shoulder. They start to exit slowly. Second stops.

SECOND 
Oh no. I'm sorry.

NIFTY

Sorry for what ... oh no you did not just shit your fucking pants!

Nifty drops him on the floor and moves away. Second clutches his stomach.

NIFTY

No way I'm touchin this shitty pants dude. That's where I draw the line. CHARLOTTE!

I'm sorry. I'm sorry.

\section{SECOND}

Charlotte comes running in with Luis behind him. Charlotte crosses to Second.

\section{CHARLOTTE}

Oh my. It's okay, hunny. Let's get you an Ativan and a shower. Come on.

Charlotte pulls Second $u$, but is struggling.

CHARLOTTE

I don't suppose you could help me.

No way.

NIFTY

\section{LUIS}

Something stinks.

NIFTY

I ain't gettin paid so no way I'm carrying a dude around that's got shit all over him.

What's that smell?

LUIS

NIFTY

He shit himself, dumbass.

LUIS

Oh. Gross. I'll help.

Luis helps pick Second up.

NIFTY

You're fucked up, you know that, Luis. 
What? Why?

\section{LUIS}

NIFTY

Nothing. Go ahead. Help her. Just make sure you wash your hands.

CHARLOTTE

Thank you Luis. Good to know there is at least one gentlemen left in this world.

NIFTY

Shit. I'm the gentlemenliest of all the gentlemen.

I'm sorry.

SECOND

CHARLOTTE

Come on, hunny. Let's get you cleaned up.

Charlotte and Luis help Second offstage. Nifty is left on-stage.

NIFTY

(to audience)

What up? You understand why I couldn't help just then, don't you? I mean, c'mon. A man has limitations. I'm Nifty. Real name is Roger. I like opiates. You know like Vicodin, Percocet, Fentanyl- all that shit. Broke my leg 'bout three years ago fallin out a damn tree. Long story. Anyhow, the doctors gave me some Vikes and the next thing I know I'm taking like twenty a day and robbing people and stealing shit just so I could get more. Well, I got caught - again - and the judge sent me here. My detox was just as bad as Second's there, 'cept I was smart enough to sleep by the toilet. Don't worry - I won't hold this little incident over his head or anything. Nah, I won't give him a hard time. That ain't like me. That ain't me.

\section{Robert enters.}

Whoa. What's so damn rank?

ROBERT

NIFTY

Homeboy shit his drawers.

\section{ROBERT}

Oh. Okay.

Robert crosses to his bed and lays down.

NIFTY 
Seriously. That's all you have to say about it. "Oh. Okay."

ROBERT

What? Not like it's abnormal. It's why we should be in a separate room from those in detox.

NIFTY

Aren't you still considered in detox?

\section{ROBERT}

Technically. But still.

NIFTY

What do you think about the new kid?

\section{ROBERT}

Seems alright. You know he blew a point two eight when he got here?

Is that high?

NIFTY

\section{ROBERT}

How do you not ... Yeah, man. That's borderline gonna die type stuff.

NIFTY

Wow. Dudes here are fucked up.

\section{ROBERT}

How was Group?

\section{NIFTY}

Man. Patrick's alright you know. He makes some good points, but I hate how he always starts every sentence with "To be honest" or "To tell you the truth" or "Honestly." I'm like, just be honest. Why can't he just be honest, you know and not preface every sentence by stating that you are getting ready to be honest.

What?

\section{ROBERT}

NIFTY

You'll see, when you come to Group. You got Patrick too, right?

ROBERT

Yep.

NIFTY 
Oh. So does Luis. And me. We'll be in Group together. Patrick's cool. He's smart. Been through some shit. Hey, you wanna hit up the smoke shack?

\section{ROBERT}

Sure. I got a dip in, but I can smoke and dip. The more nicotine the better.

NIFTY

Good. Let this place air out.

\section{ROBERT}

Yeah. You got cigarettes?

\section{NIFTY}

No, but you know Luis does. His Dad left him a carton.

\section{ROBERT}

What are we gonna do when he leaves?

What do you mean?

\section{NIFTY}

\section{ROBERT}

When Luis leaves, what are we gonna do about cigarettes?

Oh. Yeah. I'll just steal us some.

\section{NIFTY}

Robert and Nifty exit. Charlotte and Second enter. Second is in different clothes and looks a lot better. A couple days have passed since the incident.

\section{CHARLOTTE}

Well. Your vitals look good. You say you feel good?

\section{SECOND}

Yeah. I do. Thanks. And thanks again for helping me out the other day. Pretty embarrassing.

\section{CHARLOTTE}

Oh, hunny. I've seen much worse. You weren't the first and you won't be the last. My detox almost killed me.

Wait. You're // an ...

\section{SECOND}

\section{CHARLOTTE}

Alcoholic Addict. My DOC was downers, but I was into everything. 
DOC?

\section{SECOND}

\section{CHARLOTTE}

Drug of choice. Been sober for almost ten years now. I was a patient here. Former Good House patient, current Good House med tech.

Oh wow.

\section{SECOND}

\section{CHARLOTTE}

It's been almost ten years, but I still do it one day at a time. Helping people like you get sober keeps me sober. That's why I do it. It's a bit selfish, but for me its life or death. I go out again and it'll kill me. I'm sure of it.

\section{SECOND}

I don't know if I'd call it selfish. I sure appreciate it.

\section{CHARLOTTE}

Well, you are very welcome, hunny. In one more day, you can call Erica. We let her know that you were okay.

She called?

\section{SECOND}

\section{CHARLOTTE}

Three times a day. You got a good one there. A lot of folks show up here and they got nobody. You're lucky.

I know.

\section{SECOND}

\section{CHARLOTTE}

Well, I gotta get back to the front desk. We won't do vitals again for another eight hours. I believe you have your first appointment with Patrick soon. And you can start going to Group whenever you are ready. Day after tomorrow, you'll be out of detox and you'll be required to go. A little advice, though, the sooner you get involved the sooner you'll get to go home.

\section{SECOND}

Good to know. Thanks. Isn't there a Group going on now?

\section{CHARLOTTE}

Sure is. Small group. Patrick is meeting with his patients. You can join them if you want.

\section{SECOND}


Okay. Where is that?

CHARLOTTE

Go down the hall. Fourth door on your left. Room Fourteen.

SECOND

Okay. Again, thank you for everything.

CHARLOTTE

It's my pleasure, hunny.

Let the healing begin!

\section{SECOND}

CHARLOTTE

The physical part's almost over. Your body is starting to heal. Now it's time to get your mind right.

Yeah. Well. See ya.

\section{SECOND}

Second exits.

Have a good day, hunny.

CHARLOTTE

Charlotte stays. Turns and faces audience.

CHARLOTTE (CONT)

Chances are he won't make it. Sure, he'll probably make it through here. But more than likely he'll relapse. I know it sounds pessimistic, but it's the sad truth. I have seen hundreds of patients come through here and about maybe ten out of every one-hundred stay sober. Another ten out of a hundred will be dead within a couple years. I'd like to think that Second there might be different, but I won't get my hopes up. I've learned not to - if I did, I would probably relapse. (beat) Thirteen years ago, I killed somebody. A nineteen-year-old boy. I fell asleep at the wheel, went over the median and hit him head on. I came out without a scratch. The doctors said because I was so intoxicated my body was so relaxed that it helped it to not get injured. How's that for irony? I did a couple years in prison, but I stayed high in prison. Then, the judge agreed to let me out if I would come here. It was here that I learned to let go and let God. I don't know why I was the way I was, but I'm just glad I got another chance. I think about that boy every day. His name was Chase Albert Wright. I pray to him every day that I'm making amends to him for what I did. I never thought I could forgive myself, but then I came here, and my counselor told me that forgiving myself is above my paygrade. That only God has the power to truly forgive. I think God has forgiven me, but how can you ever really be sure. Just in case, I will keep doing what I'm doing and helping people like Second until I can't 
do it anymore. One day at a time. One patient at a time. Speaking of that, I better get back to work.

\section{Charlotte exits.}

Second enters.

\section{SECOND}

(to audience)

I made through detox. As you may have noticed, it was not what I'd call a good time.

As Second speaks Patrick, Nifty, Luis, and Robert enter and set up chairs and sit in a semi-circle.

\section{SECOND (CONT)}

I can't believe I shit myself. Please don't tell anyone about that. Definitely the low point of my existence. Sorry about that. Well ... so . . I f feel pretty good. Different, you know ... I've never been to counseling. I don't even really know what they do. Counsel, I would imagine.

\section{Small Group.}

Second crosses to where the group sits.

SECOND

Uhhh. Hello.

NIFTY

Shit storm!

\section{ROBERT}

How long you been waitin' for that one?

What's a shit storm?

\section{LUIS}

NIFTY

Dude.

\section{LUIS}

What?

\section{PATRICK}

Alright. How about everybody shuts up. 


\section{SECOND}

Charlotte told me I could come join you.

\section{PATRICK}

Of course. You must be John, but I hear everybody calls you Second.

\section{SECOND}

That's right.

\section{PATRICK}

Well. Let's get you a chair. Nift, go get Second a chair from Room Thirteen.

NIFTY

Why me?

\section{PATRICK}

Because I said so.

\section{LUIS}

I'll do it.

\section{PATRICK}

No, Luis, you won't. Honestly, this is not an opportunity for anyone to sneak a cigarette. Nifty, get the chair.

NIFTY

Man. Alright. But I better get a gold star or something.

\section{PATRICK}

What'd we talk about, Nifty? What's the number one cause of addiction?

\section{NIFTY}

Doin drugs.

\section{PATRICK}

Nope. Drugs are symptom of what?

\section{LUIS}

I know.

\section{PATRICK}

Let him answer, Luis.

I don't know. Selfishness.

NIFTY 


\section{PATRICK}

Bingo. See I am getting through that thick skull of yours. Now go get the damn chair.

NIFTY

Alright.

\section{Nifty exits.}

\section{PATRICK}

So Second, do you know everybody here?

\section{SECOND}

Yeah. We are all roommates.

\section{PATRICK}

No shit. Well that's not supposed to happen.

Why not?

\section{ROBERT}

\section{PATRICK}

To be honest, it's because we don't want you all of you to be in your rooms sitting around bitching about how much you don't like your counselor. You'll conspire together.

\section{ROBERT}

Us? Complain? Conspire? Come on. So, you're saying they fucked up?

\section{PATRICK}

Somebody did. Isn't the first time, won't be the last.

\section{ROBERT}

So how come we have to stay in the same rooms we detox in?

\section{LUIS}

Man, you are obsessed with that. What's the big deal?

\section{Nifty enters with chair.}

\section{NIFTY}

Here you go. Don't make a mess on it.

\section{SECOND}

I'm never going to live this down, am I?

\section{NIFTY}

Not a chance. 


\section{ROBERT}

I just don't think it's fair that we go through detox then have to watch others do it. No offense, Second.

None taken.

\section{SECOND}

\section{ROBERT}

I mean. Having to try and sleep by somebody that's sick and throwing up and shaking and all that crap - it's disgusting.

\section{PATRICK}

And why might you think that we choose to do that?

ROBERT

Save time. So you don't have to move patients around.

Ehhhh. Wrong. Anybody else?

\section{PATRICK}

NIFTY

So we can deal with patients so you lazy asses don't have to.

PATRICK

I'll just pretend you aren't speaking, okay Nifty?

What? Am I wrong?

NIFTY

\section{PATRICK}

Yes. Luis? Care to take a shot?

\section{LUIS}

Uhh. Maybe so we don't forget what were like when we came in here.

\section{PATRICK}

Ding, ding, ding! Good, Luis. There might be hope for you yet.

You think?

\section{LUIS}

\section{PATRICK}

I do. Honestly, I do. See. To be honest, one of the most important things you need to take away from this place is that recovery is an ongoing, never ending, life-long process. It means continually going to AA or NA meetings. Why do you think it's so important that you go to meetings? 


\section{ROBERT}

Because when others share their stories it reminds us of what we used to be like.

And ...

\section{PATRICK}

Silence.

\section{PATRICK}

Come on. Think about it. Same principle as being in the same room with a detoxing patient.

Ummm, can I talk?

\section{SECOND}

\section{PATRICK}

Of course, Second. That's why we're here.

\section{SECOND}

Ummm. Okay. Well, I guess because if you are in AA and go to meetings you will have to see new people come in and that can remind you of yourself when you first started.

Nice.

\section{PATRICK}

\section{NIFTY}

Damn.

\section{ROBERT}

That makes sense.

\section{PATRICK}

That's real good, Second. Exactly. In AA or NA, the most important aspect of any meeting is the newcomer. We try to make them feel welcome and that they are in a safe place where they can be honest and open. Helping a struggling newcomer reminds us of where we once were. Make sense?

\section{SECOND}

I'm sorry. You keep saying "we." Are you an alcoholic?

\section{PATRICK}

Very much so.

SECOND

Oh. 
Patrick was crazy-insane.

\section{PATRICK}

Yes I was. Still am. But now I exhibit my insanity in different ways. These guys already know my story, though. I'll tell you about myself when we meet this afternoon. How about you tell us about yourself?

\section{SECOND}

Ummm. Okay. Well, my name is John Silver. I'm actually John Silver, the Second. When I was a kid, my Dad didn't want to call me Junior, so he started calling me Second. I've been going by that since I can remember. I'm sorry, do you want to know like my life history, or like my drinking history?

How about a little bit of both.

\section{PATRICK}

SECOND

Okay. Well. My childhood was pretty normal, except my Dad died when I was twelve.

NIFTY

Of what?

\section{ROBERT}

Would ya just let him talk.

NIFTY

Man. I's just askin.

\section{PATRICK}

Fellas.

\section{SECOND}

It's okay. Cancer. Skin cancer. My Mom remarried a few years later and moved out to California. That wasn't a big deal though, I'm glad that she's happy. But we don't talk much. I'm sure she doesn't know that I'm here. Not much she could do anyway. I have one brother. He's in the military. Lives in Germany. Don't talk to him much either. I guess I started drinking in high school, you know, and kept drinking through college.

You graduated college?

NIFTY

Yeah.

SECOND

\section{PATRICK}


Nifty. The yapper. Shut it.

NIFTY

My bad. Go'on with your bad self, smarty pants.

\section{SECOND}

Well, I drank a lot in college, I guess. After school, I got a job. I still drank a lot - went out a lot. Did some cocaine and smoked weed sometimes, but all I every really wanted to do was drink. About three years ago, I met my fiance, Erica. She's great.

You got a picture?

\section{NIFTY}

Yeah.

\section{SECOND}

Second reaches back for his wallet.

\section{PATRICK}

That's not necessary. Please go on. Nifty, I swear I'll put muzzle on you if you don't shut up.

Muzzle? Shit. I'd like to see you try.

\section{NIFTY}

ROBERT

Would ya just be quiet.

\section{PATRICK}

Hey. Robert. This is my group.

\section{ROBERT}

Fine. The guy cannot shut up, though.

You got a problem?

\section{NIFTY}

Yeah, Robert. You got a problem?

\section{LUIS}

NIFTY

My man. Always got my back.

\section{PATRICK}

Gentlemen! Enough. Please, Second. Go on. They will be quiet and let you speak. 


\section{SECOND}

Okay. Well, as some point, I'm not even real sure when, I guess within the last six months or so, I started waking up in the mornings shaking real bad and I realized the only thing that would take that away was another drink. So, I started drinking all day, every day. I managed to hide it from Erica for awhile, but she figured it out. I mean how could she not. Anyway, she said I had to come here or she was gonna leave me. So, here I sit.

NIFTY

That's it. You didn't go to jail or nothing?

\section{SECOND}

Well, I've got two DUIs, but I've only spent one night in jail.

NIFTY

That ain't shit, man.

\section{PATRICK}

Alright. Thanks, Second. Thank you for that. Sound familiar to you guys?

\section{ROBERT}

Yep.

\section{LUIS}

I have pretty much the same story, except I was doing heroin. And I came in here because my parents made me.

\section{NIFTY}

That's not the same story.

\section{LUIS}

Same in that I started with a little and it just got more and more until I couldn't stop.

NIFTY

Heroin ain't the same as alcohol.

\section{PATRICK}

Why not?

NIFTY

What ya mean?

\section{ROBERT}

He means, it's all the same. Or at least similar. It's all chemicals we put in our bodies to make us feel different.

\section{PATRICK}


Or not feel all. Let me ask you something, Second, if you don't mind.

\section{SECOND}

Sure.

Have you ever had just one drink?

\section{PATRICK}

\section{SECOND}

Ummm. Not that I can recall.

\section{PATRICK}

Think about it. We'll talk about it this afternoon. Our time is almost up, anybody got anything else they would like to discuss. Luis, you are leaving the day after tomorrow. How ya feeling about that?

\section{LUIS}

Pretty good. I got that sponsor yesterday. Thanks, Patrick.

My pleasure.

\section{PATRICK}

\section{LUIS}

I'm going to a meeting the day I get out and planning on doing ninety in ninety.

I'm sorry. Ninety in Ninety?

\section{SECOND}

NIFTY

Ninety meetings in ninety days. They say it's what you need to do to stay sober.

\section{PATRICK}

Is that what we say you need to do?

NIFTY

It's what they suggest.

\section{PATRICK}

Yes. These are all only suggestions. Suggestions that work. What else you have planned, Luis?

LUIS

Well, my Dad is gonna get me a job at the store.

NIFTY

He still gonna hook me up? You promised. 
He said he would.

\section{LUIS}

\section{PATRICK}

What about the old circles? How you gonna stay away from those? Remember: change all...

People, places and things.

\section{PATRICK/LUIS}

\section{LUIS}

I know.

\section{PATRICK}

So, your plan?

LUIS

I don't know. I guess just not hang out with all those people. Like I said, I still owe my dealer that money. I'm sure he'll come looking for it.

\section{PATRICK}

You talk to your Dad about that?

\section{LUIS}

Yeah. I talked to him, but he doesn't really understand the seriousness of the situation.

Why not?

\section{PATRICK}

\section{LUIS}

He just says stuff like, "if he comes to the house, I just won't let him in" or "If he shows up, I'll call the cops." You know, dumb shit like that. He don't get the Heroin world. It don't work like that.

\section{PATRICK}

So what are you gonna do? Remember, it's all about having a plan.

\section{NIFTY}

I got your back homey. Just lay low til I bounce outta here. I ain't gonna let nothin happen to you.

\section{PATRICK}

You really think that way of thinking is gonna work for you outside these walls?

Done worked for me so far.

\section{NIFTY}




\section{PATRICK}

Really? That's why a judge sent you to rehab?

NIFTY

They got the wrong guy.

\section{PATRICK}

Yeah. Now we know that's not true.

\section{NIFTY}

You know what. You people in here. You don't know shit. You ain't got no idea what my life is like. What I deal with every day. You and your cushy fucking job, sitting here telling us how to live our lives.

Calm down.

\section{PATRICK}

NIFTY

Nah. Fuck that. I'm sick of being calm.

Nifty stands up.

NIFTY (CONT)

First, I get thrown in here by some judge that don't know the difference between a Vicodin and a goddamn aspirin. Dumb motherfucker. Then I get put in here with all these dudes and get some counselor that don't have a damn clue what it's like to be me and telling me how to live my life and shit. (pointing to Robert) Then I gotta watch homeboy throw up all over everything for three days straight and (pointing to Sec) then watch this motherfucker shit himself and spend two more days crying out for God to help him. Bunch of whiny fuckin pussies!

Robert stands.

I'm sorry. You just call me a pussy?

ROBERT

Yep.

NIFTY

Patrick stands. So does Luis. Luis moves over, getting on the side of Nifty. Second stands too.

PATRICK

Everybody, just calm down. Let's talk about this.

NIFTY 
Man, I'm sick of talking. All we do up in this motherfucker is talk.

ROBERT

I bet that mouth of yours gets you in a lot of trouble.

\section{NIFTY}

I bet that ugly face of yours attracts quite a few fists, old man.

\section{PATRICK}

Alright. There's going to be no fists. Everybody sit.

\section{SECOND}

Yeah. Hey, just calm down.

\section{NIFTY}

Shut the fuck up, new kid.

\section{SECOND}

Hey man!

\section{NIFTY}

What the fuck you gonna do about it? Hell, I'll take on all y'all motherfuckers.

\section{PATRICK}

Nobody's doing nothing about anything. Nifty, I just want to remind you, that if you throw a punch, you will go to prison. No more rehab and straight to a cell. That's the agreement.

Man. Fuck that.

\section{NIFTY}

\section{PATRICK}

How would your Mom feel about you going to prison for two years?

NIFTY

Man, don't bring Ma into this.

\section{ROBERT}

Your "Ma" should of taught you some manners.

Man, you done fucked up now.

\section{NIFTY}

Nifty tries to punch Robert, but Patrick catches his arm and twists it behind Nifty's back, trips Nifty and pins him to the floor. 


\section{PATRICK}

Robert, Second, Luis, I want you to leave.

\section{ROBERT}

What?

\section{PATRICK}

Please. Go back to your room. I want to have a little conversation with Roger here. GO! NOW!

Fine.

\section{ROBERT}

\section{LUIS}

You gonna be okay, Nifty?

\section{PATRICK}

He'll be fine, Luis.

\section{LUIS}

You ain't going to send him to jail are you?

No, Luis. Go to your room.

\section{PATRICK}

NIFTY

I'll be alright, homey. This ain't nothin I ain't used to.

Okay. I'll be in the room.

\section{LUIS}

Luis exits. Patrick lets go of Nifty's arm. Nifty jumps up and faces Patrick.

PATRICK

So, you gonna tell me what that was all about?

What you mean?

\section{NIFTY}

\section{PATRICK}

That tirade. You gonna tell me what's going on with you? You want to go to prison? We can definitely make that happen.

No.

NIFTY 
Then talk.

\section{PATRICK}

NIFTY

I ain't got nothing to say.

You wanna know what I think?

\section{PATRICK}

NIFTY

What?

\section{PATRICK}

I think you're scared about Luis leaving.

What? Nahhh. I don't give a shit.

NIFTY

\section{PATRICK}

Sure. You keep telling yourself that. Thing is you care about Luis and he cares about you.

NIFTY

I ain't gay.

\section{PATRICK}

No, that's not what I'm saying. I wouldn't give a shit if you were. The thing is, with you Nift, all the people in your life that you care about leave you. It's textbook fear of abandonment.

Fear of what?

\section{NIFTY}

\section{PATRICK}

Abandonment. When all the people you love leave you when you don't want them to, you can develop a fear of the next people you love leaving you. The fear manifests itself in different ways. Isolation, obsession and, in your case, anger or acting out. Make sense?

That ain't me.

\section{NIFTY}

\section{PATRICK}

It's okay to feel these things. You are supposed to feel sad when people leave. It's part of life. One of the reasons people use substances is so they don't have to feel. Opiates are especially good at taking pain away. Both physical and mental. I won't get into the science of it, but it's what they are supposed to do and they work. All I'm saying, it's okay to be upset that Luis is leaving. 
Yeah.

\section{NIFTY}

So you good?

\section{PATRICK}

NIFTY

Yeah. I just . . . I'm worried about him, you know. I don't know that he's gonna make it. He says he's got this plan, but I just don't know.

\section{PATRICK}

Right now, just take care of yourself. That's what you are here for. Let me worry about Luis. He's gonna be nervous about leaving, so he needs your support.

Alright.

NIFTY

\section{PATRICK}

And apologize to your roommates.

Man.

NIFTY

Apologize.

\section{PATRICK}

NIFTY

Fine.

PATRICK

You want me to go with you?

\section{NIFTY}

No. I got it.

\section{PATRICK}

Good. Now get outta here.

Thanks, Patrick.

\section{NIFTY}

No worries. It's what I do.

\section{PATRICK}

Nifty exits. 
Patrick faces the audience.

\title{
PATRICK \\ (to audience)
}

When I was twenty years old, I had a friend named Jeff that really wanted to go into the military. We were into everything at the time: alcohol, cocaine, crack, ecstasy, heroin, you name it. My buddy, Jeff, he was sick of it, all the drugs, you could tell. But he kept hanging out with us, you know, doing the same things we were doing. Hell, we would even give him a hard time if he didn't use with us. Well, he wanted to join the army so he went to the recruiter and got everything lined up. One of the stipulations was he had to do a drug test. So, he disappeared for a few days to clean out his system. All of the sudden he shows back up and tells us that he got into the army and wants to have one last huge party at his house. He was really excited to be doing something with his life. To be getting out of the scene. At the party, we were all really loaded, and we were dancing in the living room. I remember the song - U Can't Touch This, you know - that song by MC Hammer. In the middle of the party, he gets a phone call and all of the sudden he comes into the living room and looks all bummed out. Apparently, the army got his drug test results mixed up or something and he actually didn't pass his drug test, so they weren't going to let him join. Well, Jeff went back into his room, came out with a shotgun, stood right in the middle of us all, put the barrel in his mouth and blew his brains out. You wanna know why I do what I do? That's why.

Patrick sits.

\section{Patrick's Office.}

Second enters.

Have a seat.

\section{PATRICK}

Thanks.

\section{SECOND}

Thans.

How you doing?

\author{
PATRICK
}

\section{SECOND}

Okay, I guess. Looking forward to talking to Erica tomorrow.

PATRICK

I bet. How'd it go when Nifty got back to the room?

SECOND

A little tense, but he apologized, and everything seems to be fine. 


\section{PATRICK}

The patients in here are really dealing with some heavy stuff. Working through it is not always pleasant. Many of the men that come in here are used to solving problems with their fists. In here that can cause a great deal of trouble, especially for those on a probationary sentence from a judge.

Huh.

\section{SECOND}

\section{PATRICK}

About thirty percent of patients are in here because a judge makes them. We won't go over thirty percent, otherwise it gets a little out of hand.

Why is that?

\section{SECOND}

PATRICK

Well, being forced to go to rehab is a lot different than volunteering to go. Speaking of, you thought about checking out yet.

Almost every minute of the day.

\section{SECOND}

PATRICK

What day is this?

\section{SECOND}

Five.

\section{PATRICK}

Well I hope you stay.

\section{SECOND}

That's the plan.

\section{PATRICK}

Good. So, you told me a little about yourself during Group. Tell me more.

\section{Like what.}

\section{SECOND}

\section{PATRICK}

Well, I asked you to think about whether you ever just have one drink.

\section{SECOND}

Yeah. No. I've never just had one. Guess that makes me an alky, huh? 


\section{PATRICK}

Well yes, kind of. A lot of things do. The fact that you are in rehab is a pretty tell-tale sign that you have a problem with alcohol. You are an alcoholic, Second. Do you realize that?

Yeah. I guess.

\section{SECOND}

\section{PATRICK}

You guess? That's not good enough. Tell me, when you take a drink, can you stop?

\section{SECOND}

No.

\section{PATRICK}

You lose your ability to stop even when you want to?

Yeah.

\section{SECOND}

\section{PATRICK}

That's called powerlessness my friend. The first step to any recovery is admitting you have a problem. Our first step states: We admitted we were powerless over alcohol - that our lives had become unmanageable. Does that sound like you?

\section{SECOND}

I guess. I mean the powerless part. I'm not sure my life was unmanageable, though. I mean I still had a job.

Tell me, what are you doing here?

\section{PATRICK}

What do you mean?

\section{SECOND}

\section{PATRICK}

At The Good House. Why ya here? Why'd you decide to come spend twenty-one to twenty-eight glorious days with us?

\section{SECOND}

Twenty-one. I can only stay twenty-one at the most.

\section{PATRICK}

Let's not worry about that for now. One day at a time. One moment at a time. Why ya here? What do you want from treatment? 


\section{SECOND}

To get sober.

\section{PATRICK}

Done. You're sober. Why you wanna be sober?

\section{SECOND}

I don't know. So I'm not drunk all the time.

\section{PATRICK}

Why can't you be drunk all the time?

\section{SECOND}

I don't know. Cause I shouldn't be drunk all the time.

\section{PATRICK}

What'll happen if you continue to drink?

\section{SECOND}

Erica will leave me.

\section{PATRICK}

And ...

\section{SECOND}

I'll lose my job.

\section{PATRICK}

And ...

\section{SECOND}

I could maybe get another DUI and go to jail.

\section{PATRICK}

And ...

\section{SECOND}

And, I don't know.

\section{PATRICK}

And what about you? How do you feel being drunk all the time? Most people that come in here don't come in here cause their lives are all hunky-dory. How does it feel? Think back to the day you came in here. How'd you feel that day?

Miserable.

\section{SECOND}




\section{PATRICK}

And there it is. Being a drunk is a fucking miserable occupation! I swear I was the least fun alcoholic-addict ever. Just mean and depressing and obnoxious. Not happy, not fun, just fricking miserable.

I don't think I was that bad.

\section{SECOND}

\section{PATRICK}

Really? So you were on the brink of losing your fiance, your job, ending up in jail, to sit at home, drink and be miserable. That's not that bad, huh?

\section{SECOND}

I get your point.

\section{PATRICK}

Good. Look. Honestly, this is all for nothing if you don't admit you have a problem. If you go through this without admitting you are powerless, you will have another drink. And it'll only be worse. Trust me.

Okay.

\section{SECOND}

What do you think?

\section{PATRICK}

\section{SECOND}

About what?

\section{PATRICK}

Gonna take skill to crack through that noggin of yours, isn't it? Here's what I want you to do. Before we meet in a couple days, I want you to make a list of all the bad shit that has happened to you because of drinking. Then I want you to make a list of all the good things that have happened to you because of drinking. Bring in those lists and we'll talk. I need to go Vape. You smoke?

No.

SECOND

PATRICK

One of the rare ones.

Looks like it.

\section{SECOND}

\section{PATRICK}


To be honest, you might think about taking it up while you're here. It's a good way to make friends.

\section{SECOND}

I'm sorry. But are you telling me to start smoking? In an addiction treatment center?

\section{PATRICK}

Did I say that? I didn't say that. Can I tell you a secret, Second?

\section{SECOND}

Go ahead.

\section{PATRICK}

You're here because you don't want Erica to leave you, right?

In a nutshell, yeah.

\section{SECOND}

\section{PATRICK}

Well, that's okay for now. It's a good motivator.

That's the secret?

\section{SECOND}

\section{PATRICK}

No. Well, I guess the secret is really only a secret to you. Everybody else knows it.

What's that?

\section{SECOND}

\section{PATRICK}

You my friend are a full-fledged fucking alcoholic.

Patrick pokes Second on the forehead.

\section{PATRICK (CONT)}

The sooner you get that tattooed into that brain, the sooner you can start feeling the freedom of a life without alcohol. Say it with me.

Say what?

SECOND

My name is Patrick.

\section{PATRICK}

\section{SECOND}


My name is Patrick.

No, your name, numb nuts.

PATRICK

Oh. My name is Second.

SECOND

PATRICK

And I'm an alcoholic.

SECOND

And I'm an alcoholic.

PATRICK

Now put it all together.

\section{SECOND}

My name is Second and I'm an alcoholic.

Again.

PATRICK

What?

\section{SECOND}

PATRICK

Say it again.

SECOND

My name is Second and I'm an alcoholic.

PATRICK

Again.

SECOND

My name is Second and I'm an alcoholic.

Louder.

PATRICK

SECOND

My name is Second and I'm alcoholic!

PATRICK

Fucking scream it! 


\section{SECOND \\ MY NAME IS SECOND AND I'M AN ALCOHOLIC!!! \\ PATRICK}

Those are only words my friend. It's your actions that matter. I'm going to Vape. See ya next time.

Patrick exits.

Second stands and turns toward audience.

A Pause.

\section{SECOND}

My name is Second and I'm an alcoholic. (Beat) Huh.

Second exits.

\section{Outside of The Good House.}

Nifty and Luis enter.

\section{NIFTY}

So whatcha gonna do?

LUIS

Go to meetings. Talk to my sponsor. Work the steps.

Besides that.

NIFTY

LUIS

Oh, you mean the dealer.

NIFTY

Yeah, man. You gotta steer clear of him until I get out.

What if he finds me?

\section{LUIS}

NIFTY

He won't. Just hide at home. Go to meetings, go to work and go home. Your Dad will be with you all the time won't he?

\section{LUIS}

Yeah. But, like I said, my Dad, he just doesn't get it. 
You want I talk to him.

\section{NIFTY}

\section{LUIS}

No. That won't help, believe me.

NIFTY

You got any money to give to your dealer.

\section{LUIS}

I don't have shit.

\section{NIFTY}

I ain't got shit either.

\section{LUIS}

It'll be alright. I'll just do like you said. I'll hide til you get out. You still wanna stay at my house?

You sure your Dad won't care?

\section{NIFTY}

\section{LUIS}

Nah. He don't really pay attention.

\section{NIFTY}

Hell yes, then. I got nowhere else to go. Man, I ain't never met no one who's been as cool to me as you, Luis. You're alright, you know that.

\section{LUIS}

It ain't nothing. This place would have been really boring without you here. And you kept me from leaving and using. If it wasn't for you, I'd be high right now.

\section{NIFTY}

Ahhh man. I didn't do that. You did. I just nudged you in the right direction.

\section{LUIS}

I'm gonna miss you man.

\section{NIFTY}

Ahhh, hell, I'll be out in a week. You'll be sick of me before you know it.

I doubt that.

\section{LUIS}

Robert, Charlotte, Patrick and Second enter. Charlotte is carrying a backpack. 
You outta here?

\section{SECOND}

\section{LUIS}

Looks like it.

\section{NIFTY}

That's right. My boy gradgeeated!

\section{LUIS}

I don't know about all that.

\section{PATRICK}

Your ready. Stick to the plan and you'll be fine.

\section{SECOND}

Good luck to you.

You gonna stick it out?

\section{LUIS}

\section{SECOND}

I, uhhh, I . .

\section{LUIS}

Stick it out, man. It's worth it. I learned a lot from this place. Listen to Patrick. He knows what he's talking about.

Why thank you.

\section{PATRICK}

\section{SECOND}

Okay.

\section{LUIS}

Promise me, you'll stay. You don't want to lose that beautiful lady of yours.

\section{NIFTY}

Wait til she meets me. That'll be all she wrote. No woman can resist the irresistible Nift.

\section{Redundant.}

\section{ROBERT}

\section{NIFTY}

Redund-this. 
LUIS

(to Second)

You promise.

\section{SECOND}

I promise. Now get outta here.

\section{LUIS}

Well. This is it.

\section{Robert hugs him.}

\section{ROBERT}

Remember. Go to meetings. Meet with your sponsor. Work the steps.

I got it.

\section{LUIS}

Good.

\section{ROBERT}

\section{PATRICK}

Doin my job for me again, Robert. Thank you.

Robert moves away.

Here's your stuff, hunny.

\section{CHARLOTTE}

Charlotte hands Luis the backpack.

\section{CHARLOTTE (CONT)}

And you know you ain't gettin outta here without a big squeeze from Charlotte!

Charlotte grabs Luis and hugs the crap out of him.

\section{CHARLOTTE}

You take care of yourself, okay, hunny.

I will.

\section{LUIS}

Charlotte pulls away. Nifty steps in to give Luis a hug.

\section{LUIS}

I'm gonna miss you my friend. 


\section{NIFTY}

You're my brother. Always my brother.

\section{LUIS}

I know it.

NIFTY

Now get a move on, man. I'll hit you up in a week.

\section{LUIS}

Okay.

\section{NIFTY}

Kiss The Good House goodbye.

\section{PATRICK}

Your Dad here yet?

\section{LUIS}

He's on his way.

\section{PATRICK}

You sure?

\section{LUIS}

Yeah. I just talked to him.

\section{PATRICK}

Alright then. Everybody else inside. Group starts in five.

Patrick exits.

Bye sweet boy!

\section{CHARLOTTE}

She goes inside.

See ya man.

ROBERT

\section{Robert exits}

Later, Luis.

\section{SECOND}

\section{LUIS}


Promise you'll stay?

Sure.

SECOND

Good.

LUIS

Good.

Later.

\section{SECOND}

Second exits.

\section{NIFTY}

Don't forget me man. Stay hidden and I'll talk to you soon.

Alright.

\section{LUIS}

Nifty turns to exit.

\section{LUIS (CONT)}

Wait. Nift. I just wanna say. Well. Thanks for being my friend. I don't know that I ever really had a true friend. So. Yeah. That's it, I guess. Thanks.

My man. Take it sleazy.

\section{NIFTY}

Nifty exits.

Luis stands for a moment then addresses the audience.

\section{LUIS}

My Dad picks me up. We go home. I ask my Dad to take me to a meeting and he says he can't because he's watching a game. I ask if I can have the car and he says no. So, I go to my room and I'm just sitting there, chilling you know, reading my Big Book when there's a knock on my window. It's my old dealer. I don't know how he found out I was out or where I live. Word travels fast I guess. He wants his money. I tell him I don't have it and that I just got out of rehab. He doesn't give a shit. He hands me a bag of dope and tells me I have to sell it for him to repay my debt or he's going to kill me. I don't know if he would really kill me, but I'm scared anyway. So there I am, sitting in my room with a bag full of heroin and I've only been out of rehab for less than five hours.

\section{Luis exits.}

The nurse's desk in The Good House. 
Charlotte enters. She is on the phone.

CHARLOTTE

I understand. Yes. Thank you for letting us know.

Nifty and Second enter. They see that Charlotte is upset.

NIFTY

Good Charlotte. What's the haps?

Hey. You okay?

\section{SECOND}

\section{CHARLOTTE}

I should probably let Patrick tell you this, but I'm not sure where he is. That was the police. They just picked up Luis.

NIFTY

Man. He got arrested already. That dumb ass.

No, Nifty. He OD'd. He's dead.

\section{CHARLOTTE}

NIFTY

What? Nahhhh. I mean he was just here.

\section{CHARLOTTE}

Shoot. I should of let Patrick tell you. You gonna be okay, hunny?

NIFTY

Me. Yeah. I'm good.

\section{SECOND}

You sure, Nift?.

NIFTY

Ahh hell. Another one bites the dust, huh? Nuttin new in Nifty's world.

\section{SECOND}

Maybe we should find Patrick.

\section{NIFTY}

Nahh. I'm gonna ... I'll be out at the smoke shack if you need me.

Nifty runs away. 
He's not okay.

\section{SECOND}

\section{CHARLOTTE}

I know, hunny. I'll get Patrick.

\section{SECOND}

I'll help you find him.

\section{CHARLOTTE}

See if he's out front. I'll check the offices.

\section{SECOND}

Okay.

Second exits one way, Charlotte the other.

ZACH enters. He is carrying a suitcase.

\section{$\mathrm{ZACH}$}

(calling out)

Hello. Is anyone around? I'm here to check in.

\section{Robert enters.}

$\mathrm{ZACH}$

Hey man. Is this where I check in?

\section{ROBERT}

Yeah. Charlotte is usually up here, I'm not sure where she is. Your new, huh?

\section{$\mathrm{ZACH}$}

Yeah. Judges orders.

\section{ROBERT}

You detox already?

\section{$\mathrm{ZACH}$}

In jail.

\section{ROBERT}

Bummer.

It was no thing.

$\mathrm{ZACH}$ 


\section{ROBERT}

That right? Well, I'll find Charlotte, or somebody that can help you. It's weird - there is usually always someone up here. Not sure what's going on.

\section{$\mathrm{ZACH}$}

Maybe somebody died.

\section{ROBERT}

Ha! Wouldn't surprise me. I'll be right back. You'll probably be in our room. We've got a bed open.

\section{$\mathrm{ZACH}$}

Cool. Thanks. Hey. (whispers) You wouldn't happen to know anybody that's holding, would you?

Holding what?

$$
\text { ROBERT }
$$

\section{$\mathrm{ZACH}$}

Never mind.

\section{ROBERT}

I'm just a lonely old drunk. You keep that other shit to yourself.

\section{$\mathrm{ZACH}$}

Whoa, man. Chill. I was just kiddin.

\section{ROBERT}

Sure you were. On second thought, just wait here. I'm sure somebody will be here soon.

Robert exits.

\section{$\mathrm{ZACH}$}

(to audience)

What? Don't look at me. I could give a shit less about your feelings.

Zach exits.

Outside The Good House.

Nifty enters. Walking slowly with his head down. He starts punching the air. First slowly then uncontrollably.

Patrick enters. He runs to Nifty and grabs him by the shoulders. Nifty looks at him and then embraces Patrick. Nifty lets it all out. Patrick squeezes him tight. 


\section{PATRICK}

Come on.

They exit.

Second enters on one side of the stage and Erica comes in other. They both have phones in their hands.

\section{ERICA}

So how are you?

\section{SECOND}

I'm good. I'm good.

ERICA

You sound good.

\section{SECOND}

Thanks. You sound sexy.

\section{ERICA}

Second.

\section{SECOND}

I miss you babe. Too much testosterone in this place.

\section{CHARLOTTE}

(from offstage)

I heard that!

\section{SECOND}

If you don't want to hear it, then don't listen in on people's conversations. Sorry, babe.

What was that?

\section{ERICA}

\section{SECOND}

You remember Charlotte?

\section{ERICA}

Of course.

\section{SECOND}

Just her listening to every word I say. 
You know it, hunny.

\section{SECOND}

So what's going on with you, babe?

\section{ERICA}

Oh. Same ole, same ole. But I wanna hear about you. When I talked to you a few days ago, you told me that guy, Luis, your roommate had died. You okay?

\section{SECOND}

Yeah. I'm fine. My other roommate, Nifty, is pretty shaken up. They were close.

\section{ERICA}

That's really horrible. Right after rehab, he OD'd and died.

\section{SECOND}

Yeah. I guess it's dangerous cause their tolerance goes down after being sober and then they shoot up too much. I guess it's not that irregular.

\section{ERICA}

Wow. Doesn't sound like that place works very well.

\section{SECOND}

It doesn't. They are the first to tell you. They say one in every ten people that come here die within a year of getting out. It's crazy when you look around and wonder who's gonna live and who's going to die.

\section{ERICA}

Are you sure you should stay there?

\section{SECOND}

Yeah, babe. I'm going to stick out the twenty-one days. Maybe even stay a few days longer if Patrick thinks I should.

\section{ERICA}

Oh.

It's Patrick's call.

\section{SECOND}

Don't you wanna come home?

\section{ERICA}

\section{SECOND}


I don't understand. You're the one that wanted me in here in the first place.

\section{ERICA}

I know. But then you told me about that kid dying and I was talking to my mother and we were thinking that maybe it would be better if you just came and stayed with me.

Your mother, huh?

\section{SECOND}

\section{ERICA}

I know.

\section{SECOND}

Erica, let me tell you something. I . . I . . I I am an alcoholic. Like a bad one. And I understand that now. I don't want to be a statistic. And I don't want to lose you.

\section{ERICA}

Okay.

\section{SECOND}

I'm sorry for putting you through all this.

\section{ERICA}

Okay.

What's wrong?

\section{SECOND}

\section{ERICA}

It's nothing. I just ... I just have never heard you talk like this.

Is that a bad thing?

\section{SECOND}

\section{ERICA}

No. No. Not at all. It's really ... really ... good. I want you to take as much as time as you think you need. I just miss you is all. When can I come visit?

Anytime this weekend.

\section{SECOND}

I'm coming.

\section{ERICA}

SECOND 
Great. So let me tell you about this new roommate we got. His name is Zach. And he sucks.

Both Second and Erica exit to their respective sides.

Robert enters. While he is talking to the audience, Second, Nifty, Zach and Patrick set up for Group.

\section{ROBERT}

(to audience)

I was always just a beer man, you know. Thought it was fine if I just stuck to beer. Problem was, I would drink about forty beers a day. I know, it doesn't seem possible. But believe me, it is. Working out on a farm, sitting in a tractor all day by yourself. One time I lost my tractor. Completely lost it in the middle of a flat hay field. How do you do that when you can see for miles on all sides? That takes talent. My wife let me talk to my kids today. First time in eight years. I have a little girl, Susie, she's eleven and a teenage boy, Rusty. He's fourteen. Fourteen. Last time I saw him, I hit him. Right across the face. I don't even know what he did, you know, for me to hit him. (beat) Anyway, today I got to talk to my kids. If I was my wife, I don't know that I would have ever forgiven me. She asked me if I asked God for forgiveness and I told her I had. She said that was good and then she put Rusty on the phone. He remembered me. He was excited to talk to me. (beat) I can't imagine how Luis' father must feel. I know one thing, I'm gonna do whatever it takes to earn back the trust of my family.

Robert crosses to join Group. Zach is telling his story. Nifty is still not doing well. He is quiet.

\section{$\mathrm{ZACH}$}

So, we were way up on top of this water tower and I was like, jump motherfucker, jump! And he was all scared and crying and shit. It was so hilarious, I was laughing so hard, I almost fell over the side. Well he ended up calling the // cops and ...

\section{ROBERT}

Sorry I'm late. I was talking to my son.

\section{SECOND}

Hey man, that's great.

\section{PATRICK}

How'd it go?

\section{$\mathrm{ZACH}$}

Hey, do you mind? I was right in the middle of telling my story.

\section{PATRICK}

Just hold up a second. This is an important step for Robert. 
But I was just at the good part.

\section{SECOND}

That was the good part? You trying to talk a kid into committing suicide. It's sadistic.

\section{$\mathrm{ZACH}$}

What does that mean?

\section{PATRICK}

It means you enjoy it when other people are in pain.

Huh. Cool.

\section{$\mathrm{ZACH}$ \\ $\mathrm{ZACH}$}

PATRICK

No. Not cool. Anyway. Robert. So it was good?

\section{ROBERT}

Yeah. I was nervous, ya know, callin her. I didn't know if she would of even talk to me. But she was totally cool. Like, she was happy to talk to me. And then talking to my son. Wow. I'm just, ya know, it feels like the promises are already coming true. I mean, you all know I've been to rehab before, but this time, this time, I really think it's gonna stick.

\section{$\mathrm{ZACH}$}

Man, you actually sound like you like this place.

ROBERT

Well, that's because I actually do like this place.

Me too.

\section{SECOND}

\section{$\mathrm{ZACH}$}

Why?

Why what?

\section{ROBERT}

\section{$\mathrm{ZACH}$}

(mocking)

"Because I actually like this place." Come the fuck on.

ROBERT

You got a problem, man? What's his problem, Patrick? 


\section{PATRICK}

There's no problem. Zach, how about you just take it down a notch.

\section{$\mathrm{ZACH}$}

What'd I say? Man, you guys need to chill the fuck out. Ya take this shit way too seriously.

\section{PATRICK}

Yeah, we do. People in this room have a lot to lose, Zach.

\section{$\mathrm{ZACH}$}

Like what?

Second?

\section{PATRICK}

SECOND

My fiance. My job. My freedom.

\section{PATRICK}

Robert?

ROBERT

My son.

Nifty?

PATRICK

What?

NIFTY

PATRICK

You've been pretty quiet.

NIFTY

So.

PATRICK

Just tell us. What do you have to lose?

\section{NIFTY}

I don't know. My life.

PATRICK

Yeah. Tell me Zach. You ever disappoint anybody? 
Why you puttin me on the spot?

\section{PATRICK}

You put yourself there.

\section{$\mathrm{ZACH}$}

Man. I just wanna get my damn paper signed and get the hell out of here. I don't have to answer your questions.

\section{PATRICK}

No. No you don't. At least not right now.

\section{$\mathrm{ZACH}$}

Good. Can I go?

\section{PATRICK}

Go? No. Group ends when I say it ends.

\section{$\mathrm{ZACH}$}

Fine.

\section{PATRICK}

Good. Robert, I'm glad things went well with your wife and son. That took a lot of courage.

\section{$\mathrm{ZACH}$}

Oh, come on.

\section{SECOND}

Hey man, why don't you just shut up.

\section{$\mathrm{ZACH}$}

Why don't you shut me up?

\section{SECOND}

What?

\section{ROBERT}

Patrick. This isn't very productive with this guy in here.

\section{$\mathrm{ZACH}$}

Productive? What's being productive? I mean, didn't your last client just die?

What the fuck you say?

\section{NIFTY}




\section{PATRICK}

Okay.

Hey man, not cool.

\section{SECOND}

\section{$\mathrm{ZACH}$}

The last guy that was in my chair. Didn't he go through all this shit then just go out and die like the next day. Super counseling, counselor.

\section{NIFTY}

Man. You don't have a motherfuckin clue what you're talkin bout. Best if you just shut the fuck up.

\section{$\mathrm{ZACH}$}

Whoa-ho-ho! Hit a nerve.

\section{PATRICK}

ALRIGHT! We are done here. Zach, go outside.

\section{Zach stands.}

\section{$\mathrm{ZACH}$}

Fine by me. Ya need me, I'll be smoking. Later chumps. You know, he's got ya'll brainwashed. Grow the fuck up or you'll end up like the last guy. What a dumb ass.

Nifty jumps up and grabs Zach by the throat.

NIFTY

Motherfucker.

Everybody jumps up and pulls Nifty off.

PATRICK

Why does this keep happening? EVERYBODY CHILL!

$\mathrm{ZACH}$

Looks like I'll be needing a new group counselor.

\section{SECOND}

Looks like we'll be needing a new roommate.

\section{$\mathrm{ZACH}$}

Fine by me. You're lucky I don't report this. (to Nifty) You'd be going straight to the joint. 
Zach exits.

SECOND

Man, that guy is like the opposite of cool.

\section{PATRICK}

You okay, Nifty?

\section{NIFTY}

Yeah.

\section{ROBERT}

Patrick. We need a new roommate. That guy is messing up our whole thing. It's hard enough after Luis. Can you make something happen?

\section{PATRICK}

Yeah. I'll see what I can do. For now, just stay away from him.

\section{ROBERT}

Fine by me.

\section{NIFTY}

Yeah. I ain't needin nothin from that dude.

\section{SECOND}

I swear I haven't ever met anyone who defined the word "sucks."

Now you have.

\section{ROBERT}

\section{PATRICK}

Everybody good?

They all nod.

\section{PATRICK (CONT)}

Get out of here. Sec, stick around, would you?

Sure.

SECOND

Nifty and Robert begin to exit.

You gonna be okay, Nift?

SECOND (CONT) 
Nifty looks back.

Yeah.

NIFTY

Nifty and Robert exit.

\title{
PATRICK
}

Have a seat.

This place is nuts sometimes.

\section{SECOND}

PATRICK

A little bit different than the outside world, huh?

\section{SECOND}

It's like being on another planet.

\section{PATRICK}

Yeah. Look. You seem like you are doing pretty well. What are you, about fifteen days in?

\section{SECOND}

Yep. Six and wake up if you give me the green light.

\section{PATRICK}

I'll know in the next couple of days.

I trust you.

\author{
SECOND
}

\section{PATRICK}

You seem like a really solid guy, Second.

\section{SECOND}

I like to think so. Except for the whole alcoholism thing.

So what gives?

\section{PATRICK}

I don't follow.

\section{SECOND}

\section{PATRICK}


You had everything going for you. College educated. Somewhat stable family. Good job. Great girlfriend turned fiance'. But you were ready to fuck that all up. Why?

\section{SECOND}

I don't know.

Sure you do.

\section{PATRICK}

No. I don't.

\section{SECOND}

\section{PATRICK}

Yes you do.

\section{SECOND}

If you are trying to get me to admit I was molested as a kid or something, nothing like that ever happened. I told you that already.

Then what?

\section{PATRICK}

\section{SECOND}

I don't know.

PATRICK

Ahhh. Come on, Second. There's gotta be something.

I mean my Dad died.

SECOND

\section{PATRICK}

That's not it.

SECOND

How do you know?

\section{PATRICK}

I know. It's my job. And I am VERY good at my job.

My Mom moving away?

\section{SECOND}

\section{PATRICK}

Nope. 
Then I don't know.

\section{SECOND}

\section{Then I don't know.}

\section{PATRICK}

(forcing the issue)

It's gotta be something, John Silver, Jr.

Why that?

\section{SECOND}

Why what?

\section{PATRICK}

The full name?

\section{SECOND}

\section{PATRICK}

That's who you are, isn't it?

\section{SECOND}

Rather go by Second.

\section{PATRICK}

Fine. That brother of yours, the military// guy, he .. .

\section{SECOND}

My brother and I were fine. We are fine.

\section{PATRICK}

Then what is it? Why IN THE FUCK would you ruin your life?

I don't know.

\section{SECOND}

PATRICK

OH, COME ON!

\section{SECOND}

Why are you yelling at me?

\section{PATRICK}

ENOUGH BULLSHIT! GIVE ME SOME TRUTH!

I swear! I don't know!

\section{SECOND}


PATRICK

COME ON, SECOND - YOU REALLY HAVE NO IDEA WHY YOU WOULD

WASTE EVERYTHING? YOUR CAREER? YOUR LIFE? ERICA? YOU WOULD

BREAK HER HEART. WHY?

\section{SECOND}

I DON'T KNOW! YOU HEAR ME! I DON'T KNOW!!!

\section{Second breaks down.}

Hey. Second.

\section{PATRICK}

SECOND

What?

\section{PATRICK}

It's okay not to know.

\section{SECOND}

What? But you // just ...

\section{PATRICK}

Yeah. That's what I do.

\section{SECOND}

You're an asshole.

\section{PATRICK}

The truth is, it could be all those things, it could be none of those things, and it could be something locked in your brain that just doesn't want to come out. In the end, it doesn't really matter.

What the hell I am here for then?

\section{SECOND}

\section{PATRICK}

To learn what I just told you.

\section{SECOND}

Oh.

\section{PATRICK}

You cannot blame anything or anyone for your alcoholism. You own it and it is YOUR responsibility to manage it. You don't need therapy. You need recovery. Understand? 
I do.

\title{
SECOND
}

\section{I do.}

Look at me.

\section{PATRICK}

\author{
SECOND
}

I understand.

\section{PATRICK}

Good. Now, one more thing. These guys - they look up to you. You might not see that, but they respect somebody that has their shit together.

I don't see that.

\section{SECOND}

I want you to do a favor for me.

\section{PATRICK}

Sure.

\author{
SECOND
}

Keep an eye on Nifty.

\section{PATRICK}

\section{SECOND}

Why?

\section{PATRICK}

He's just, I can tell he's not doing well. I mean he's not saying much and that means he's hanging out in his head and when someone like Nifty spends too much time in his head, bad things can happen.

\section{Okay.}

\section{SECOND}

PATRICK

I just want you to look out for him, that's all. He's in a rough place with what happened to Luis. Can you do that?

Sure.

\section{SECOND}

PATRICK 
I think you'll find that helping others might be one of the keys to your recovery. I've had people like you come through here before, and it worked for them. They got less baggage to sort out, so they need another focus. That make sense?

I think so.

SECOND

\section{Ithink so.}

Trust me.

PATRICK

I do. But you know Nift.

\section{SECOND}

I just need you to be his friend.

\section{PATRICK}

We're already friends.

\section{SECOND}

\section{PATRICK}

Just try to get him to talk. He needs to talk.

\section{I got it.}

\section{SECOND}

Good. By the way, how is Erica?

\section{PATRICK}

\section{Erica enters with a bag of stuff and sits.}

SECOND

She's good. Coming tomorrow for a visit.

Great. Now get out of here.

\section{PATRICK}

\section{SECOND}

Til next time.

\section{PATRICK}

Next time.

Patrick exits one way and Second crosses and joins Erica.

Hey, babe!

\section{SECOND}


Erica jumps up.

Second!

\section{ERICA}

They hug and kiss.

\section{SECOND}

Whoa there. You gonna get me all friskified.

Second.

\section{ERICA}

\section{SECOND}

What?

ERICA

Gosh, babe. You look great.

\section{SECOND}

I do? I mean, so do you.

\section{ERICA}

Yeah, you're like, not bloated.

\section{SECOND}

Well thank you.

\section{ERICA}

So, how are things going?

\section{SECOND}

Okay. We are having some roommate trouble, but it'll work out.

Oh. The guy that sucks.

\section{ERICA}

\section{SECOND}

\section{Yeah.}

\section{ERICA}

How about the other guys?

\section{SECOND}

Nifty's supposed to leave tomorrow. Gonna be a bummer, but I'm happy for him. 


\section{Nifty enters.}

\section{SECOND (CONT)}

Well! Speak of the devil. Hey Nifty, this is my fiance you've been dying to meet. This is Erica.

Erica stands and shakes his hand.

\section{ERICA}

Hi. I've heard a lot about you.

\section{NIFTY}

That so?

\section{ERICA}

Second says you've been a good friend. He needs good friends.

Really?

NIFTY

SECOND

Erica, come on.

NIFTY

Well, it's nice to meet you. I gotta, uhhh, I gotta get goin.

\section{SECOND}

What? That's it. You're not gonna throw the famous Nifty-mack. I thought you were dying to steal my lady away. Show her what a real man is.

Yeah. Not today, okay.

NIFTY

Okay.

\section{SECOND}

It was nice to meet you.

\section{ERICA}

NIFTY

Yeah.

Nifty exits.

\section{SECOND}

Huh. Not sure what that was all about. 
He seems nice.

\title{
ERICA
}

\author{
SECOND
}

He's just ... well, he's just had a rough go, that's all.

\section{ERICA}

I bet. So, I brought some wedding stuff for us to look at.

Great.

\section{SECOND}

Erica pulls out a couple magazines from her bag and starts flipping through them. Second stands and steps toward the audience.

\section{SECOND \\ (to audience)}

Wedding stuff. Good times. (beat) I feel good. I have to say, I feel like a changed man. I almost feel like sometimes I don't belong in this place. The other people in here, they're lives are hard. They all seem to live with this feeling that they've disappointed everyone. That they let everybody down. It's not even about the alcohol and drugs. It's about the disappointment. The unfulfillment of dreams. The inability to feel like they can get back what they've lost. It makes me realize how lucky I am. I mean, after meeting these people, I just, well, I just feel blessed. Lucky. Look at this beautiful woman behind me, planning our wedding. If I have that, what else do I really need?

Nifty enters and gets into his bed.

\section{SECOND (CONT)}

I've been looking out for Nifty and he was doing okay, but now, he's just . . . well, something's wrong. He's just not the same. I think Luis was all he had. I try to talk to him, but it's just. . . It's not working. I just, well, I wish everybody could get out of this place the same thing I have. But, I know that's not possible. I wish it was, but it's just not.

Second turns back to Erica.

\section{SECOND (CONT)}

Hey babe. How about we go for a walk?

\section{ERICA}

That's sounds nice.

Erica puts her magazines away, stands and grabs Second's hand and they begin to exit. As they are walking off, Second turns to the audience and smiles.

\section{A Patient Room in The Good House.}


Nifty lays in bed. He stares up at the ceiling. A few moments pass and Second enters.

You wanna go smoke?

\section{SECOND}

\section{NIFTY}

Your lady gone?

\section{SECOND}

Yep. C'mon. Let's go. I didn't smoke all day cause I didn't want Erica to smell it.

NIFTY

I can't believe you started smoking in rehab.

I'll quit when I leave.

\section{SECOND}

NIFTY

Yeah. Cause quitting things is what we are good at.

\section{SECOND}

You know it. You just gonna stay in bed all day? You keep this up, they won't graduate you and you'll have to do your back-up.

NIFTY

Look at you. Got the rehab lingo down. They ain't gonna send me to do my back-up. Not after what happened to Luis.

\section{Robert enters.}

\section{ROBERT}

Hey fellas.

\section{SECOND}

I was just telling Nifty here that he better get his ass out of bed or they might send him to do his back up time.

How short are you?

\section{ROBERT}

\section{NIFTY}

Tomorrow was supposed to be the day, but it don't look like that's happenin.

\section{ROBERT}

It would be if you would get your ass up. 
NIFTY

Mind your own business.

\section{ROBERT}

Fine.

\section{SECOND}

He's just saying, you know Patrick's not gonna let you go home if you don't start going to Group and the meetings.

Whatever. How short are you, Robert?

NIFTY

\section{ROBERT}

Not long. Six days. But I might leave earlier. I really need to get back to work. What you got Sec?

\section{SECOND}

Well, technically I can leave whenever I want.

ROBERT

Yeah we know.

\section{SECOND}

But I'll probably stay another seven.

NIFTY

Damn. We all short timers.

\section{SECOND}

Yep. Kinda crazy. You seen Zach?

\section{NIFTY}

Yeah. What about him?

\section{SECOND}

Nothin. Just wish the dude would check out already. I don't understand why they couldn't just move him out of our room.

Bureaucratic bullshit.

ROBERT

Why? What'd you hear?

\section{NIFTY}

\section{SECOND}


Well I'm pretty sure he snuck out last night.

He's prolly just gettin a snack.

\section{NIFTY}

Besides he's just a total dick.

\section{SECOND}

\section{ROBERT}

I think its best that we all just keep avoiding him.

\section{SECOND}

I mean the dude has issues. Major fucking issues that go way beyond addiction.

\section{NIFTY}

I'd think twice before you believe your ass is better than him.

\section{SECOND}

Whoa, man. I thought we all agreed that he sucks and has absolutely no interest in getting sober.

I agree with that statement.

\section{ROBERT}

SECOND

I heard he might even be using.

NIFTY

What? Who thinks that? Did Patrick say something?

SECOND

No, just overheard a conversation around the smoke shack.

Who?

NIFTY

You know something we don't, Nift?

\section{ROBERT}

\section{NIFTY}

No.

\section{ROBERT}

I didn't tell you guys this because I don't go around talking about other people's business, but I ran into him when he first got here and he asked me if I was holding. 
What? You gotta tell Patrick.

\section{SECOND}

ROBERT

No, I don't.

SECOND

They can get his ass out of here and he can stop ruining it for everybody else.

NIFTY

Ain't no snitching happenin, Second. You still got a lot to learn about how this shit works.

Whatever. I'm telling Patrick.

\section{SECOND}

Second begins to exit. Nifty jumps out of bed and grabs him.

NIFTY

You can't do that, man.

\section{SECOND}

Why not? This is a treatment center for people who are trying to quit doing drugs. People can't bring shit in here or it defeats the whole purpose.

NIFTY

You can't tell nobody, man.

What's your deal?

\section{SECOND}

ROBERT

I know what it is. You're using, aren't you Nift?

NIFTY

Fuck you.

\section{ROBERT}

That's why you don't want him to say anything, isn't it? You're getting pills from him or something. That's why you're staying in bed all day.

That's not it, is it?

\section{SECOND}

\section{NIFTY}

Damn, you are one naive motherfucker, you know that? 
What's your problem?

\section{SECOND}

NIFTY

I don't like snitches.

\section{ROBERT}

Just calm down. He hasn't said anything to anybody.

NIFTY

He's going to. I can tell he's going to. Rich, righteous asshole.

\section{SECOND}

Rich?... why you being like this?

\section{NIFTY}

Let me splain something to you. You go tell Patrick or Charlotte or anybody that works here that you know somebody's holding, they will search and drug test everybody.

So.

\section{SECOND}

\section{ROBERT}

So, he'd piss dirty.

\section{NIFTY}

And to the joint I'd go. I'm not going to prison because you can't keep your goddamn mouth shut.

\section{ROBERT}

He's not going to say anything.

NIFTY

Why don't you just go home? You don't belong here, Junior.

\section{SECOND}

If you know you'd go to prison, then why the hell would you do drugs.

\section{NIFTY}

Cause I'm a drug addict. That's what I do.

But Luis.

\section{SECOND}

\section{NIFTY}

Don't even go there. 
Luis would be so disappointed.

\section{SECOND}

Hey Second. Lay off.

\section{ROBERT}

\section{SECOND}

No. We come in here. We sober up. We talk all this stuff about how we want to get better and do better and be sober and be happier and more spiritual and all that crap. And now you're telling me that one fucking guy comes in here and offers you some pills and you take them.

\section{NIFTY}

You are so green. You're about as green as a motherfuckin St. Pattie's Day parade.

\section{SECOND}

Stop saying I don't know shit. Just because you're some street-hustler-drug-addictcriminal does not mean you're smarter than me. It just means you are better at being a fuck up.

Watch yourself.

NIFTY

\section{SECOND}

Why, Nift? Why take the pills from him?

\section{NIFTY}

I didn't take the pills from him. I asked him to get them for me. He simply obliged.

You can't be serious?

ROBERT

NIFTY

As a motherfuckin' heart attack.

\section{SECOND}

Why?

NIFTY

Why do you think?

\section{SECOND}

Cause of Luis.

\section{NIFTY}

You're damn right cause of Luis. 


\section{SECOND}

Because you were sad? Come on.

NIFTY

You wouldn't understand.

\section{SECOND}

Try me.

\section{NIFTY}

I don't have to explain myself to you.

\section{SECOND}

Yes you do.

\section{NIFTY}

No I don't. I don't owe you a damn thing.

Nifty pushes Second. Right then, Zach enters.

What's going on guys?

$\mathrm{ZACH}$

\section{SECOND}

Who the fuck do you think you are, bringing drugs in here and giving them to a drug addict?!!

\section{$\mathrm{ZACH}$}

Whoa dude.

\section{SECOND}

You're a piece of shit.

\section{$\mathrm{ZACH}$}

Hey, man. I was just doing the guy a favor. He said he was hurting and I said I could help him take the pain away. That's what I do. I'm a drug dealer. Take it or leave it.

I can't believe this.

\section{SECOND}

\section{$\mathrm{ZACH}$}

Who is this guy? Some kind of self-righteous asshole? This is the real world man, you might as well start living in it.

ROBERT

(to Zach) 
I think it's best if you get out of here right now.

Eat a dick, old man.

$\mathrm{ZACH}$

What?

\section{ROBERT}

\section{$\mathrm{ZACH}$}

What you hard of hearing? I said, EAT. A. BIG. FAT. VEINY. DICK. OLD MAN.

ROBERT

Is that right? Well.

Robert rushes Zach and punches him in the face. Zach fights back. Nifty and Second pull them apart.

Everybody just chill!

\section{NIFTY}

Zach is totally amped up. He crosses to his bed and from under the mattress he pulls out a knife.

\section{NIFTY}

What the hell? No way man. Where did you get a fucking knife?

\section{ZACH}

I ain't afraid to cut a motherfucker.

I'm getting help.

\section{SECOND}

\section{NIFTY}

No. Second. Just chill. Everybody just chill. The only thing that can happen here is that we all get kicked out and I go to fucking prison. We don't want that do we?

\section{$\mathrm{ZACH}$}

I don't give a motherfuck. I'll twelve-twelve like a boss.

\section{ROBERT}

You better put that knife down.

\section{$\mathrm{ZACH}$}

You gonna have to come get it, you crotchety old shitbag.

\section{ROBERT}


I'm only forty-four you turd.

Robert steps toward Zach.

NIFTY

No, Robert. Just chill. Please, just chill.

$\mathrm{ZACH}$

"Just chill, everybody just chill." You sound like a faggot.

What is your problem, man?

\section{SECOND}

NIFTY

What'd you just call me?

$\mathrm{ZACH}$

I called you a faggot. Heard you were in love with that Luis kid. Sounds pretty faggotty to me.

NIFTY

You got a death wish or somethin?

\section{SECOND}

Come on. This is treatment center. Put the knife down, Zach.

\section{$\mathrm{ZACH}$}

I'll cut all of ya. I don't give a fuck.

\section{ROBERT}

Fine with me.

\section{NIFTY}

What do ya say, Bobbie boy? Should we just end this motherfucker?

ROBERT

I'm in.

This isn't happening.

SECOND

\section{$\mathrm{ZACH}$}

Well come on.

Nifty and Robert start to close in on Zach. 
Please don't do this.

\section{SECOND}

Just then, Patrick enters quickly.

What the hell is going on , , ,?!!!

\section{PATRICK}

Patrick runs up behind Zach. Zach turns quickly and the knife plunges into Patrick's gut. Patrick falls to the floor.

\section{PATRICK}

Honestly? You gotta be kidding.

Patrick!!!

\section{SECOND}

Nifty grabs Zach and throws him to the ground. Nifty and Robert proceed to kick the shit out of Zach.

\section{SECOND}

Help!!! Help us! Please, somebody help me!!!

Patrick bleeds on the floor and Nifty and Robert proceed to kick Zach in his face and side.

Everybody suddenly freezes. Everybody except Second. He stands and steps toward audience.

\section{SECOND}

(to audience)

Fear. It's fear. Huh. Well I'll be damned.

\section{Lights Down.}

\section{Outside of The Good House.}

Lights up.

Charlotte and Second stand side by side. Second is holding his suitcase.

You ready?

CHARLOTTE

Yeah. I think so.

\section{SECOND}




\section{Good.}

\section{CHARLOTTE}

Any word on Patrick?

\section{SECOND}

\section{CHARLOTTE}

He's going to be fine. Actually gonna be back at work next week if you want to give him a call.

I'll do that. Know anything about Nifty?

\section{SECOND}

\section{CHARLOTTE}

He's gonna have to do his back up time.

Robert?

\section{SECOND}

\section{CHARLOTTE}

No idea. I'm sure he's in some trouble, but probably won't be that bad. That's if he stays sober.

Yeah.

\section{SECOND}

\section{CHARLOTTE}

You remember what you have to do?

\section{SECOND}

Go to meetings. Get a sponsor. Work the steps.

That's right.

\section{CHARLOTTE}

\section{SECOND}

How do you do it, Charlotte? How can you deal with all the tragedy in this place? The disappointment?

\section{CHARLOTTE}

Because, every once in awhile someone comes along that really wants help. They come here, to The Good House, and they figure out how to change their life for the better.

Instead of losing everything, they gain a life. Now, I won't say everybody gets quite the same experience you had.

\section{SECOND}


I would hope not.

CHARLOTTE

But you got a glimpse into this world. Most people want to ignore it even exists. I hope you don't.

I won't.

\author{
SECOND
}

\title{
Erica enters.
}

Hey babe!

\section{ERICA}

Erica runs to Second, hugs him and kisses him.

You ready to go home?

\section{ERICA (CONT)}

\section{SECOND}

Yeah. I am.

\section{ERICA}

Hi Charlotte.

\section{CHARLOTTE}

Hi Erica. You got yourself a good one. Hold on to him.

I know.

\section{ERICA}

Erica pulls out four envelopes from her purse and hands them to Charlotte.

What are these?

\section{CHARLOTTE}

\section{ERICA}

Save-the-dates.

\section{SECOND}

One for you. One for Patrick. And if you know how, could you get one to Nifty and one to Robert. I figure you might have billing addresses for them or something.

I can try, hunny.

\section{CHARLOTTE}




\section{SECOND}

Well. I hope you can make it.

\section{CHARLOTTE}

If I can get a day off, I'll be there. And I know Patrick will be too.

Good.

SECOND

Second hugs Charlotte.

\section{SECOND (CONT)}

Let's go babe.

\section{ERICA}

Bye, Charlotte.

\section{SECOND}

You saved me, you know that. You all saved me.

CHARLOTTE

Oh no hunny. You saved yourself.

Second and Erica begin to exit one way. Charlotte the other. Charlotte stops.

CHARLOTTE

Hey Second.

Second stops and turns.

SECOND

(to Erica)

Go ahead. I'll catch up.

Erica exits.

SECOND

(to Charlotte)

Yeah.

Just don't drink.

\section{CHARLOTTE}

SECOND

Yeah. Okay. 


\section{CHARLOTTE}

Seriously. No matter what. Just do not drink.

\section{SECOND}

I won't.

\section{CHARLOTTE}

Good.

Charlotte exits.

\section{SECOND}

(to audience)

I won't. I won't.

Lights Down.

End of Play. 


\section{Chapter 5: The Recovery Project}

\section{A Performance Ethnography Text}

\section{Introduction}

The Recovery Project is like nothing else I have ever written. Though I had read the work of Anna Deveare Smith and was a big fan, her work did not strike me as something I really wanted to do. It was not until I took a Performance Ethnography class and, at the same time, was considering what I was going to do for my dissertation, that I had the idea to create an ethnographic performance text based on recovery. I also want to stretch myself as an actor and thought I could create a text that I could use for a oneperson show. Furthermore, the idea gained more traction when I thought, if I kept it simple, I could take the show into recovery houses, meetings, possibly prisons and perform it for people struggling to find recovery.

I knew that I wanted to create an ethnographic performance text about alcoholism, but I was not sure where to start. In class, we examined and discussed the work of many ethnographers and ethnodramatists. Johnny Saldaña, a well-known practitioner and a scholar of ethnographic dramatic work (or ethnodrama as he calls it) states:

An ethnodramatic play script and its ethnotheatrical production are deliberately chosen as representational and presentational methods of ethnographic fieldwork or autoethnographic reflection because the researcher or artist has determined that these art forms are the most appropriate and effective modalities for communicating observations of cultural, social, or personal life..$^{50}$

This statement made me contemplate whether moving forward with this idea was the "most appropriate and effective" way to communicate what I wanted to say. Then it hit

\footnotetext{
50 Johnny Saldaña, Ethnotheatre: Research From Page to Stage, (Walnut Creek, CA: Routledge, 2011) 15.
} 
me, this was not about what I wanted to say, but about what others had to say. Instead of my voice shaping the message, the voices of others could do that for me. I was enthralled and began to think a great deal about how to proceed.

In my Performance Ethnography class, we talked at great length about the difficulties an artist can face when representing the "other" in an ethnographic performance. These difficulties can include misrepresentation, inaccuracies, and the idea that there is no way to take the "self" out of the examination of the "other." In many ethnographic works, an ethnographer (the self) enters an unfamiliar world to examine a people and culture that he or she wishes to learn more about. Therefore, when analysis and/or qualitative data is formed and disclosed it becomes impossible for the ethnographer to eliminate his or her effect on the results. Put more simply, an interviewer cannot, in good conscious, deny that their affective presence impacts the interviewing process; as soon as the recorder is turned on, people act differently. This was a challenge I set out to overcome.

For The Recovery Project, there was no way to take myself out of the equation. I knew I needed to personally interview alcoholics to obtain the data I needed. However, the fact that I am a part of the "other," or, rather, that I am also an alcoholic, automatically counteracts the effect of the "self" on the process. In short, it helps that I am an alcoholic too. Additionally, to get the interviewees to talk to me honestly about their experience, I decided to allow them to just tell me their story. Most recovering alcoholics have done this at some point in their recovery, so it is familiar terrain. Therefore, I decided to keep the interview to one prompt: Tell me what you were like; what happened, and what you are like now. I would then let them tell their story while I 
listened.

As I previously explained, I did not want this play to be a collection of "war stories." This was a difficult decision because "war stories" are fascinating. They usually have beginning, middle and ends and are quite dramatic in nature. These stories would make for great theatre. To me, though, that seemed too easy. If I was going to take this performance into places of recovery, then I wanted the play to be about recovery. Therefore, I decided to tell the interviewees that this was my focus. I soon found they appreciated what I was trying to do and expressed relief that I did not want them to recount much of their past, as it was to be recorded.

Finding alcoholics and addicts to record posed the biggest challenge of the project. Alcoholics and addicts tend not to want their life stories recorded as their lives usually include events they would rather keep private. This was a reminder of the sad truth about alcoholism and addiction, it carries with it a stigma that keeps people from speaking their truth. This makes recovery even that much more difficult-if those who are in recovery fear being identified as "in recovery" it only makes active alcoholics and addicts more likely to hide out of shame, instead of seeking recovery. I had five people turn down interviews after I explained to them I wanted to record. They simply did not want their story on file somewhere. I completely understood their apprehensions.

Luckily, I found five individuals who were willing to participate. In the interest of their anonymity, I will not disclose the demographical breakdown of the participants. It does not matter. In her book The Recovering, Leslie Jamison provides defense of the power of recovery stories from unknown authors. She writes:

In recovery, I found a community that resisted what I'd always been told about stories - that they had to be unique - suggesting instead that a story was most 
useful when it wasn't unique at all, when it understood itself as something that had been lived before and would be lived again. Our stories were valuable because of this redundancy, not despite it. Originality wasn't the ideal, and beauty wasn't the point. ${ }^{51}$

Jamison's statement artfully summarizes what I learned by creating The Recovery Project. Though everyone is unique, in recovery we all share a similar story. Creating this text once again assured me that I am not alone.

The interviews were a lot of fun. After the anonymity guarantee, a brief discussion about recovery instead of "war stories" and the prompt, I hit record and just sat back and listened. One thing I noticed as the interviewees told their stories was how well they knew who they are; they had figured themselves out. It was easy to tell each person had spent a great deal of time thinking about his/her life, his/her alcoholism and/or addiction and his/her recovery. Each of them carried a deep understanding of the world, how it works and his/her place in it. They were all also hyperaware that their addiction is ever-present and could reach out and grab them at any time, if they let it. Listening to their stories, then listening to them again and again became one of the most rewarding activities of my life because through their stories I learned about myself. That is the essence of why I think this text and subsequent performance can be effective.

Though this script is intended for a one-person show, I also wanted to open it up to be produced by a cast of different actors. If it is performed by an ensemble, it is imperative that gender-conscious and color-conscious casting is implemented. To that end, I gave all the characters gender-neutral names, Lynn, Jessie, Avery, Kasey, Sydney and Sam. Anyone of any type can play these characters. This also aids in the promise of

\footnotetext{
51 Leslie Jamison, 9.
} 
anonymity for the participants because it should be practically impossible to determine the sex of the character from the text.

To guarantee anonymity and to make sure the research I was preparing to do was on the level, I applied to the Internal Review Board for approval of my plan. When I conceptualized this project, I thought it may be difficult to get approval from IRB due to the need for anonymity among people in recovery, but this was not the case. I filled out the required forms and was approved after a couple of simple amendments to my original application. Upon approval, I set out to find people to interview. This was the hard part.

I knew that I wanted to use people with differing lengths of sobriety who were also active members of either AA or NA (Narcotics Anonymous). Geographically, I wanted to keep it to central Missouri, and in that endeavor, I was successful. After some searching, I found enough people. Originally, the goal was eight to ten interviews, but after I had completed five, I felt like I had enough material to complete a script.

Prior to each interview, I read the contractual statement, which guarantees the anonymity of each person participating and then explained how that would work. I told them I would, in no way compromise their anonymity. To achieve this, no one else would listen to the recordings or read the transcripts of the interviews. I also stated that if the script were to be performed, I would in no way do an imitation of the person in performance or try to embody their body or voice. Additionally, I would allow each person the right to approve the script prior to a public performance or publication. All agreed and seemed comforted by the attention I placed on their anonymity. This led to the interviewees being more open in their responses.

Another important aspect of the pre-interview process was my insistence that they 
focus more on recovery than "war stories." All the participants obliged. They were actually heartened because it gave the project a sense of purpose; that it was not going to be a staged interpretation of all the crazy stuff they did prior to recovery.

For the interview, I asked them to respond to one prompt: Tell me what you were like, what happened and what you are like now. This is common in AA storytelling and helped to put them at ease because it was language they understood. All the participants had told their story prior to this, so this allowed them to simply tell their story again — this time into a recorder. After I gave them the prompt and turned the recorder on, I just let them talk and I listened. I did not interject any questions at any point. Only in my first interview did I ask a couple of follow-up questions; but, I decided soon after, that was not necessary.

I found the responses I received to be fascinating, tragic at times, funny, enlightening, educational and uplifting; exactly what I want The Recovery Project to be. All the participants possessed deep and complicated connections to their active alcoholism or addiction and a definite sense of pride in their recovery. Their insights into recovery and how it is achieved will prove to be invaluable to audiences that experience the play.

After transcribing the recordings, I set out to piece together the script. I had no idea what a fascinating process it would be. There were many ways to approach this, but I decided to begin with some of the more profound statements then move into a linear type of story along the lines of the prompt I gave them: what we were like, what happened and what we are like now.

Anna Deveare Smith's work, as previously stated, was extremely influential on 
this project and the process I went through to complete it. Smith begins by finding a topic she wants to explore, usually an event or a social issue. She then proceeds to find as many people as she can to interview about that topic. For example, her play Twilight: Los Angeles, 1992 is an ethnographic performance that includes sixteen different perspectives on the L.A. riots. Her most recent work, Notes from the Field is the centerpiece of The Pipeline Project, which raises awareness and combats the systemic "pipeline" of youth poverty to prison. Smith says the overall mission of her life is "the pursuit of the American character." ${ }^{\text {25 }}$ Her work is exceptionally well done, and her one-person performances are second-to-none. When she discusses her work, she always comes back to the one aspect that is crucial to the success of her scripts and performances: listening.

Even though I knew I could not do what Smith does and depict the actual characters I interviewed, it did not diminish the importance I placed on listening when interviewing subjects for The Recovery Project. Smith does not pepper people with questions; she asks them a question, then listens. This was an additional reason why I only gave my subjects the one prompt. By exploring Smith's work, I realized that all I needed to do was listen and the story would reveal itself. The play would create itself if I just listened to the stories.

Each of the stories in the play relate to each other because they are stories about recovery. However, each story is unique, and each voice is unique. When editing the play together, I paid special attention to the musicality of the voices of the play. Like Deveare Smith, I wanted to capture the distinct auditory shape of each person's voice. To accomplish this in the text, instead of writing in paragraph form, I broke up the sentences

52 Anna Deveare Smith, Talk to Me, (Random House: New York, NY. 2000), 23. 
according to the pauses and beats each person used while telling his/her story. The result, I think, is sonata-like in nature. Voices in relationship with each other, playing different notes of the same song.

We had a workshop reading of the first draft recently and I was overwhelmed by the positive response. The people in the reading seemed incredibly moved by the work. The actors reading felt like their characters were distinct and possessed specific voices. Structurally, the response was that they felt like there was a good story arc but stated they would like more in the "what happened" section, i.e. the middle. I have since added to the middle. They thought that musicality existed in how the play was written and that it came across in the reading - so in that endeavor, I feel the play is successful. The reading excited me to continue to work on the play. Right now, the play is twenty-seven pages with a running time of around a half hour. This is where I want it to be, though I think I could add about ten more pages. However, I am anxious to get the play into a rehearsal room and see what happens as I build it into a one-person show. I would like to see how rehearsing the play affects the choices in the text.

The main goal for The Recovery Project is to travel a performance around to recovery facilities. I know that when I was in treatment I would have appreciated someone like me bringing in a performance like this. I think it would foster productive dialogue among the patients in the facility. If possible, I would like to perform it for their families to increase their understanding of what the patient is going through and trying to achieve. If ever possible, and if I thought the performance warranted it, I believe it would be beneficial to take the performance into jails and/or prisons. Beyond that, I want to perform this piece for the public too. I truly think everyone would benefit from hearing 
the words of these people who were willing to share their story with me. 


\title{
The Recovery Project: An Ethnographic Performance Text EDITED B Y: Aaron M. Scully
}

\author{
Characters: \\ Jessie \\ Lynn \\ Avery \\ Kasey \\ Sydney \\ Sam \\ If played by multiple actors, it is preferred that different \\ genders and/or races are represented.
}

Time:

Now

Place:

Here 
Setting: No set is needed. Perhaps a chair.

At Rise: An actor or actors appear and address the audience.

\section{JESSIE}

In about 2002 or 2003 my addiction got to the point where the compulsion to use took priority for uhh in my life over everything else I quit work My wife of 34 years divorced me

I lost a business that I loved that I built from scratch.

I had disowned mostly everyone for lack of the ability to control my using my relationships with my family

my children and my friends and I ended up homeless penniless My spirit broken therein lies the problem that most addicts encounter in active addiction a loss of their spirit and their willingness to seek a power greater than themselves. And trust in that power that they can change if they desire to And when I reached that point in my life where there was no other choice but to die or go to prison which I was looking at a prison sentence

\section{KASEY}

I had no faith in myself

I had no self-esteem

Because everything that I touched had seemed to fall apart 
And I didn't understand that

because of my

you know

Everybody else in the room

you know

They could see it

But it was just too close to my face

for me to see it

And one weekend after I got the job

we went out to celebrate

And coming back

riding the Metro back home

I missed my stop

And there is another group of people on the train

that took issue with my race and my sexuality

And probably because I was also intoxicated

I got off at the next stop

And one of them

or the group

followed me

I'm not for sure I remember

And I was beaten with a two-by-four

Uhh

I suffered from a really bad traumatic brain injury

And I was life-flighted

to the Shock Trauma Center

Now while I was in the hospital

that was right before I was supposed to start my new job

and so I couldn't do that

I lost that

I was pretty mangled 
My face was swollen

And broken

And I had contusions everywhere

And no income

They gave me

after five days of recouping in the hospital from surgery

they discharged me

with two Percocet

and a prescription I had no way of filling

ummm

So I filled that space with more alcohol

And that's not a good idea on a traumatic brain injury

(laughs)

And I was sleeping on the sofa of my friend

that I met at the psychiatric center

It was a pretty dark time

Yeah

So

I was really depressed

I had no hope for any future

I looked like hamburger

And I wanted to kill myself

\section{AVERY}

I have come to believe

that I suffer from a disease known as addiction

And that I have suffered from this disease

from the very time I was born

I believe that the disease of addiction

is in part genetically--based

But the disease itself

manifested itself in many ways over time 
I believe there a couple contributing factors

in addition

to which I state that I'm genetically predisposed

to alcoholism and addiction

and that it is my belief today

that children really only need two things

They need to be made to feel significant

and they need to feel needed

SAM

About seven years ago

Right after Christmas of 2010 I think

I turned yellow

I looked in the mirror and was like

Shit!

I'm yellow

(laughs)

I remember going to the gas station

to get another pint

And the girl behind the counter

The woman

Looked at me with this frightened look on her face

Like a surprised

uhh

declaration

"You're yellow!"

(laughs)

I remember letting it go on for days

The "yellowing"

Hiding in my house

Drinking

Finally, I looked on the internet 
And it said that I probably had jaundice

That my liver was shutting down

My body was toxic

Still

I kept drinking

I called a buddy of mine who is a nurse practitioner

It was a Sunday night

I remember

He told me to stop fucking around

And go the ER

So

Reluctantly

I did

I drove myself to the ER

They did blood tests and stuff

And I remember the doctor on duty

He seemed scared

After the tests

the nurse told me I could go home

I was walking out the door

And the nurse called after me

And stopped me

And said the doctor changed his mind

And he wants me to check in to the hospital

I did

the next day

I woke up in the hospital

And my family doctor was there

He told me that if I would have went home

And drank more

I would have been dead within 24 hours 
I had actually almost drank myself to death

Drank myself to death

How stupid does that sound?

The sad thing is

This near-death experience

It only kept me sober for about three months

My eyes were yellow

And as soon as they turned white again

I was slamming vodka

That is the power of this disease

It's so powerful it can change you

It can even make you change colors

(laughs)

\section{LYNN}

So often what I hear in AA meetings

and what is great about AA

is how much you realize you're not

so very alone

And it's really been an amazing thing in my life

And all the way back to my youngest years

As an only child

I often felt different just like they

Just like they

Say often

I often felt different and felt

like I needed

to work on fitting in

instead of fitting in

And I found myself

comparing myself to a lot of other people

And so oftentimes I was in large groups of people and stuff 
And so oftentimes

And this is just as childhood

It would often be the rowdy kids or whatever

and even with them I would be the rowdiest of them all

\section{SYDNEY}

My story started a long time ago

Uhhh

Umm

uhhh

After my husband passed away

I went pretty much full-tilt boogie

And I was drinking some

But mostly doing drugs

I got busted in '95

Even while

you know

They were busting me in my house

I knew it was the best thing

that could happen to me at the time

and that

you know

I had absolutely no clear positive thought in my brain

I was just like

Just

Just

Uhh

A mode

And there was no stopping me

Then when I went to jail

Of course, you get assessed

And the only thing I could think to say was 
I want to learn to think right again

I just want to learn how to think right

\section{JESSIE}

I can remember how they made feel

How the alcohol made feel

It gave me comfort

It gave me peace

It gave me a feeling of social interaction

And I was not

uhh

And under the influence

I was a different person

I do remember that one thing that I distinctly remember

was that I was never satisfied with one drink

I'd always be the last one standing

\section{KASEY}

I have always had a problem with alcohol.

\section{LYNN}

There were many, many, many, many good times

A lot of them

But inside me

you know

There was maybe

umm

Periodically a war going on inside myself

you know

In a lot of ways

I could say and do anything I want

I didn't know things like the golden rule

and all that.

And further along in my marriage 
right before we were leaving the big city and moving to a small town

A little teeny thing of a situation came up

And there's a guy

with a bunch of years in this town

Who talks about that

And that little thing that could be so tiny

It can just grow

And grow

And grow

And grow

And it can eventually kill you

you know

Because it will just grow into a resentment

with such enormity

it can take you down

And I've learned resentments are the number one reasons

It happened in our marriage

And it was small

And neither of us were equipped to deal with it

\section{SYDNEY}

Things were just in the right order

To sustain myself

And alcohol was just a part of me

It was just a part of my lifestyle

If you knew me

I was drinking

And I was going to make you drink too

That's pretty important

And I had no problem with that at all

I

See 
I had like

I don't have

I really cannot pinpoint

you know

Sitting and looking at myself in a mirror

and telling myself

That's something not right

AVERY

I decided to go into a drug treatment program

and I was in that program

for thirty days

And I don't know that I was that serious

about getting clean

because I really quite honestly

I really, really, enjoyed doing drugs

I really love getting loaded

And I had visions of being an old man

in a rocking chair on my front porch

you know

At the age of eighty ninety years old

Just rocking away

Smoking a big old joint

Watching the sunset

But the disease got the better of me

And took me down

Down.

Pretty hard.

JESSIE

I

As uhh

My first indication of a behavioral problem 
I had an obsessive-compulsive personality

I Would

would

Go back as far as my grade school years

when I realized that I couldn't

That umm

Umm

That I would obsessive-compulse

Obsess over candy

And could not control the amount of candy

I would eat at any given time

That was probably my first recollection

Of a

Of a

Of a

Addiction

Or nature of

Or characteristic of addiction

uhhh

in my early years of high school

And that elevated itself in areas in my life

That were not normal for other kids that were close to me

and who were my friends

In that I would obsess over

(long pause)

sexual images of the female species

and that affected my behavior

And I think

It was

I could identify that as a pleasure mechanism

that was going on in my brain 
And I would obsessive-compulse in that area

KASEY

I couldn't stay sober long enough

or not get angry enough

or

I mean

Stop myself from getting so angry

That I would go out and use

Or justify a reason to drink

And use

\section{SYDNEY}

You know

I would wake up at four o'clock

every morning

And I'd go downstairs

And I'd do six or seven shots of whiskey

And go back to sleep

Wake up at seven/eight o'clock

normal time

normal people wake up

you know

to get myself together

and go to work

But when I was getting ready for work

I'd do

six

seven

eight

shots

In-home health care

(laughs) 
Yeah.

JESSIE

As I grew older

I remember picking up my first cigarette

At about the age of sixteen or seventeen

I stole cigarettes

My brother and I would steal cigarettes

from my grandfather

When he would come visit

That was my first recollection of smoking

And ultimately it became a habit

That I developed over time

And I think that these new pleasure-seeking character

Cara

Characteristics

that I exhibited as a young person

They were probably filling some kind of void in my life

And a hole in my soul

Because of not having a male father influence

On a daily basis in my life

Growing up as a youth

I think there was something missing there in my life

And these gave me

Where I felt alone

and felt sadness

That euphoric feeling

I got from these external sources

Like sugar

Cigarettes

Sex

Helped me overcome any of these issues 
That may have been caused by my single parent upbringing.

\section{SAM}

All I really

Cared about

For twenty years of my life

Two decades

Was getting fucked up

I mean

Umm

There were other things I cared about

But I was always either

getting loaded

Or

Looking forward

to the next buzz

Drinking

or getting high

or both

\section{LYNN}

And anyway

Somewhere around that age

It was summertime

And we all ended up around some girl's house in the daytime

And I went straight to the parent's liquor cabinet

And I didn't care

I was enjoying being obnoxious

And not caring

I was in this person's house

And grabbed some bottle of something

And drank it down

And then we were 
You know we hung at the house for awhile

And we were leaving

And I drank it down like a beer

And I didn't know what I was doing

And I was in a blackout within minutes

And we all ended up at the park

And I don't know how I got there

And it was told to me later on

But apparently when I got to the park

I passed out face down into a pond

and some girl I had been nice to at school

pulled me out of the pond

and essentially saved my life

I was drowning

The police showed up and threw me in the back of the van

And took me to my parent's house

instead of the hospital

and I puked over'em for hours

and they got me

and it is all black stuff

which was probably the pond

And I woke up the next day with buckets

and newspapers around me

and I could hear my parents down there

and I didn't know what the heck had happened

But I knew it wasn't good.

And they weren't talking

But I could hear their movements

And finally I had the guts to go down and see what

And they were shocked

and terrified 
and angry

and told me the whole story.

\section{SYDNEY}

I'm calling my hotlines

(faking crying) Do you think I might be an alcoholic?

And drinking the whole time

But I knew

I wasn't thinking right

I hadn't learned how to think right yet

So that was my first detox

And it was a medical detox

You know

And I was in the hospital

and I say this with all honesty

It didn't hurt enough

It did not hurt enough

\section{AVERY}

I grew up in an alcoholic household

My earliest recollections of the environment

In which I was nurtured as a child was one of an absentee parent

Most of my young life, my father was either away in military service

During the war

or following that service his work in the private sector

Kept him away from home and we only saw him on weekends

When I did see my father

Most of that time

My recollections of him drinking and drinking substantially

Is a very vivid memory in my mind

Uhh

I lost my father when I was thirteen years old

And as a child 
while with limited exposure to my father

Do not remember my father ever telling me

one time in my life

That he loved me

Umm

That behavior on his part

combined with those needs

That I stated earlier

of young children in terms of having been nurtured

made to feel significant

And made to feel that they belong

are

Or part of

were the early contributors to me

finding outlets to deal with the pain

and the isolation of feeling alone

\section{KASEY}

I was on a trip

Where I was getting stuff

And bringing it back

And they stopped me in the airport

Because I had a three-ounce bottle

Instead of a two-ounce bottle

Maybe I forget how many ounces you need

Two ounces?

I don't know

I was over the limit anyway

And

Uhhh

I grabbed this wrong suitcase

And there was a side pocket 
That

umm

had all this paraphernalia in it

that I wasn't planning on bringing to the trip

and they confiscated that

my laptop

and all the money

cash

that I had

that I was going to get my drugs with

and umm

It just sounds like I'm talking about a whole other person

Because

The sober me

Would never consider flying on an airplane

Or going somewhere

To buy drugs

That's just nuts

But I did it

\section{LYNN}

Oblivion is what I am looking for

\section{AVERY}

And you know I think

You know

Addicts are really very interesting people

I love addicts

I love being around addicts

I love being around addicts in recovery

I love the newcomer

Because the newcomer

I was in a meeting just in the last week 
A kid

A young man

Who I had seen in meetings for over a couple of years

Evidently, he was doing the same kind of thing I was doing

Decades ago

When I first got clean

And he came into the meeting

And he took a white chip

You know

Just came back from a relapse but he came back

He knew where to go

And just the expression on his face

Just the expression on his face

Took me back to a place

That I never want to go again

I don't want to be there

And I'm so grateful for the newcomer

I'm so grateful to interact with people that come into the program

It's a constant reminder

That this disease of mine

Can take me back

Any time

Any time

\section{JESSIE}

And then something happened in April of 2009

In fact

I can remember the day

April 1 ${ }^{\text {st }}, 2009$

Where a divine

Through a divine request and prayer

I was able to put forth enough initiative 
To take myself back to California from Kansas City

And once and for all

Not go back to narcotics

And I've been clean from that day forward

I think it's different for everybody

I think the point in a person's life

Where they're not willing to pay the consequences

For their behavior associated with chemical use

Or alcohol

Or anything else that makes one feel good

Is different for everybody

And in my case

The time came where the euphoria had gone

It had disappeared

And what made that disappear

Was divine intervention

And not of my own accord

And I don't

And it's hard for us to convince other people

That that possibility exists for them

And

Uhh

But when it does the fight is over

And I

So from that day forward

Has my life has gotten better?

To people on the outside

Maybe not

But that's not what I was striving for in the first place

What I was striving for was peace within my own

Within myself 
Some sense of

of

controlling the demons

That were going on in my own

My own mind

\section{LYNN}

There were introductions

If you will

Or my returning to AA

Multiple times through my twenties

And into my early thirties

And there were sometimes when I really

Really

Really

Thought I had it

But I can look back now

And see where I really

Really

Didn't

\section{KASEY}

There went rent money

And I got evicted

And lost everything

And I needed to

People were coming through

And picking through my belongings

And I remember this one old man

Going by with his cane

And he's stopping

And with his cane

He's looking through my stuff 
And this old man is getting ready pick up something of my mother's

And I'm like

That's mine!

And he hit me with his cane!

And he's like

I'll touch this stuff if I want to

It's out on the street

And I'm like

You asshole

This is my stuff

It was an old man

and I came close to hitting him

and taking his cane or something

I mean

At least I wasn't that far gone

\section{LYNN}

I was down

I was going down that total saturation

That total

I've heard so many variations

On that description

Where it's just taking a little bit

And it's bad

So you drink some more

And it owns you some more

And it's just taking

And taking

And taking

A rapacious creditor

And umm

I wanted out 
I just wanted out

I remember at one point

Naked in my house

I rounded up every single pill

That said drown or dizziness

And rounded them all up

And I was ready

I thought about suicide before

But this time

I wanted to do it

I just

The only thing that kept me alive

Was what would my kid's life be like

If I did this

I reached that point

In my insanity

That I justified it somehow

That they'd be better off

And I didn't kill myself

I was going to do it

And it didn't happen

I remember thinking

I'm too much of a coward to kill myself

SAM

There is a difference between

Feeling like I can't drink

And not wanting to drink

My first substantial length of time

Of sobriety

Was not a happy one

I was resentful 
Though I didn't realize it

That I could not drink

That I could not join the party

Inevitably, then

Two days away from what would have been

Four years sober

I had a beer

One beer quickly turned into two beers

And within a week

I was chugging pints of Vodka

Ultimately, I ended back in treatment

And I was so pissed

The people in treatment reminded me

Through the rest of my treatment stay

How angry I was when I got there

I couldn't believe it had happened to me again

Even though every single person I met in recover

Told me that if I relapsed it would be worse

I still ended doing it

Anyway

For about five days at rehab I sulked

I moped around and just

And just

Beat myself up

Then

And I will never forget the moment

I realized that it was over

That I didn't need to struggle anymore

That I didn't need alcohol in my life

That I didn't want alcohol in my life

It was like the world got lighter 
in an instant

This weight I had carried around for years

Was finally gone

I'm not sure that until that point

I ever knew what it meant

To be happy

\section{KASEY}

I had really had enough

This was just not the way

I wanted my life to be

I wanted to have meaningful relationships

I know I'm smarter than what I was doing

But I didn't have enough self-esteem

To realize my potential goals.

I've got over a year sober now

I've had a year in school

That's really hard but it's what I wanted

And I had the support in place to get it

I have a therapist

I have a social worker

I have a psychiatrist

I have a medical doctor

It really does take a village.

JESSIE

That's not to say

That I'm perfect

In any means

In any way

That I don't have problems

I do

But I can tell you 
I'll tell you

That is was only through the twelve steps

That I was able

To establish some kind of pattern

Of connection with a higher power

On a daily basis

That has kept me clean.

There are still decisions to be made

I make in my life

And one of them first and foremost

Is not use no matter what

I still have thoughts of using

I have using dreams

Do I still have problems with sugar?

Yes, I do.

Do I still smoke?

Yes, I do.

I'm trying to curtail my cigarette smoking

Do I have sexual issues in my relationship?

Yes.

I do.

But it is healthy a relationship

I have been in

In twenty-five years

I owe that all to the 12-step program

Which I identified with

And allows us

Allows us

To participate in it

And to identify issues

That we need help with 
in our lives.

\section{KASEY}

AA gives a feeling of belonging

And we all connect on some of the

The kind of

Most obscure ways

Ways that no one else

Can really connect on

Laughing about our third DUI

Or what we said to the cop

Or some of our obsessive behavior

That comes along with this disease

Sharing stories about that

Yeah

End of Play 


\section{Chapter 6: Reflection}

Prior to embarking on this dissertation, I thought I knew the importance of stories. After all, I am a theatre artist and theatre artists are storytellers. However, I had no conception of the profound effect creating these stories would have on me. I recognized early in my recovery that it was the stories people told with which I related. I read every single story in "The Big Book" multiple times and made it a point (and still do) to be at any meeting that included a speaker telling their story. Prior to this project, though, I just chalked this phenomenon up to the fact that I liked stories. However, this dissertation has taught me that, as human beings, our ability to tell stories truly is something magical. Stories can change lives. They certainly have changed mine.

When Dr. Crespy and I first discussed writing plays for my dissertation, I, of course, jumped at the opportunity. I mean, playwriting is my thing — it is one of my favorite activities. However, I also know that playwriting is hard work. It takes hundreds of hours of mental deliberation and concentration to complete a full-length play. Whether those hours are spent in front of the computer, or, in my case, out walking my two golden retrievers Phin and Ophelia, making choices about plot, character, language and structure can be painstakingly slow and arduous. Because I knew how much work it would be, I also knew I needed the plays to be about something important to me. It did not take long for me to settle on recovery. As I mentioned in the first paragraph of this dissertation, without recovery I would have nothing. I am pretty sure I would be dead. For me, recovery is truly life or death. 
At first, I thought I was going to write plays about alcoholics. It was not until I spent a good deal of time thinking about the project that it dawned on me that the plays needed to about recovery. The single most significant personal benefit I gained from completing this dissertation is the realization that my life is not about being an alcoholic, it is about being in recovery. Prior to starting this project, I was in a different headspace. "Hello. My name is Aaron and I'm an alcoholic." This was how I thought of myself: an alcoholic. However, when I honestly considered what my relationship to alcohol really is, I made a giant leap forward. I am not an alcoholic, I am a recovering alcoholic. For this realization, I will be forever grateful that I chose to do this dissertation.

I have learned so much about alcoholism, addiction, recovery, identity, playwriting, dramatic literature and myself during this process. It has been challenging, exciting, disheartening, uplifting, miserable, joyous, frustrating, productive, boring and fun. Above all, though, it has been incredibly rewarding. I learned so much about people and the capacity of people to hope, change, get better, be better, persevere, and in some instances, simply live another day. The last line of Jean Paul Sartre's existential play, No Exit, is "Hell is other people." Perhaps, then, recovery suggests that maybe Heaven is the stories other people tell.

The purpose of these plays is to aid in the understanding of and recovery from alcoholism. By utilizing creativity, relational identity theory and a focus on recovery, I completed what I believe are effective dramatic works that have the possibility of accomplishing this goal. While I am proud of how these plays currently live as literature, to fully achieve their intended purpose, they will need to be produced. Audiences need to see them, and I fully intend to make this happen. A playwright can never really predict 
the amount of future productions a play may receive; however, there are alternative methods for ensuring a future for my works. Simply put, I may have to produce the works myself. I cannot wait to see audience reactions to fully-realized productions of Sliding into Home and The Disappointments. Likewise, it is going to be an incredible day when I stand in front of a room full of struggling alcoholics and addicts and say, "Hello. My Name is Aaron. I'm a recovering alcoholic. And this is The Recovery Project." 


\section{APPENDIX A}

\section{The Twelve Steps of Alcoholics Anonymous ${ }^{53}$}

Step 1: We admitted we were powerless over alcohol— that our lives had become unmanageable.

Step 2: Came to believe that a Power greater than ourselves could restore us to sanity.

Step 3: Made a decision to turn our will and our lives over to the care of God as we understood Him.

Step 4: Made a searching and fearless moral inventory of ourselves.

Step 5: Admitted to God, to ourselves, and to another human being the exact nature of our wrongs.

Step 6: Were entirely ready to have God remove all these defects of character.

Step 7: Humbly asked Him to remove our shortcomings.

Step 8: Made a list of all persons we had harmed, and became willing to make amends to them all.

Step 9: Made direct amends to such people wherever possible, except when to do so would injure them or others.

Step 10: Continued to take personal inventory and when we were wrong promptly admitted it.

Step 11: Sought through prayer and meditation to improve our conscious contact with God, as we understood Him, praying only for knowledge of His will for us and the power to carry that out.

Step 12: Having had a spiritual awakening as the result of these Steps, we tried to carry this message to alcoholics, and to practice these principles in all our affairs.

53 Alcoholics Anonymous, 59-60. 


\section{BIBLIOGRAPHY}

Albee, Edward. The Collected Plays. Woodstock: Overlook Duckworth, 2005. Print.

Alcoholics Anonymous: The Story of How Many Thousands of Men and Women Have Recovered from Alcoholism. Alcoholics Anonymous World Services, New York, NY, 2001. Print.

"Alcohol Facts and Statistics." National Institute on Alcohol Abuse and Alcoholism (NIAAA). N.p., n.d. Web. 08 July 2016.

Alexander, Doris. Eugene O'Neills Last Plays: Separating Art from Autobiography. Athens: University of Georgia Press, 2005. Print.

Ben-Zvi, Linda. Susan Glaspell: Her Life and Times. Oxford University Press: New York, NY, 2005). Print.

Bloom, Stephen A. “Empty Bottles, Empty Dreams: O’Neill’s Use of Drinking and Alcoholism in Long Day's Journey into Night." Critical Essays on Eugene O’Neill. US: CCG, 1984. Print.

Brantley, Ben 'Review: Anna Deveare Smith's 'Notes From the Field' Delivers Voices of Despair and Hope." The New York Times, Nov. 2, 2016. Retrieved from https://www.nytimes.com/2016/11/03/theater/notes-from-the-field-review-annadeavere-smith.html

Campbell, Thomas Michael. "Alcoholism on the American Stage: Destigmatizing Socially Constructed Depictions of the Alcoholic through Performance." Diss. 2013. (n.d.). Print.

Crespy, David A. Dreamwork for Dramatic Writing: An Organic Approach to Magic and 
Theatricality. [unpublished manuscript]. University of Missouri-Columbia. Print.

Denzin, Norman K. The Alcoholic Society: Addiction \& Recovery of the Self. New Brunswick, NJ, U.S.A.: Transaction Publishers, 1995.

Diehl, Heath A. Wasted: Performing Addiction in America. Farnham: Ashgate, 2016. Print.

Delistraty, Cody C. "The Psychological Comforts of Storytelling." The Atlantic. November 02, 2014. Retrieved from https://www.theatlantic.com/health/archive/2014/11/the-psychological-comfortsof-storytelling/381964/.

“Drunk Driving”. NHTSA, 8 Feb. 2018, www.nhtsa.gov/riskydriving/drunk-driving.

Fletcher, Anne M. Inside rehab: The surprising truth about addiction treatment - And how to get help that works. New York, NY, US: Viking, 2013. Print.

Fitzpatrick, Michael. Dr. Bob and Bill W. Speak: AA's Cofounders Tell their Stories. Center City: Hazeldon, 2012. Print.

Frick, John W. Theatre, Culture and Temperance Reform in NineteenthCentury America. Cambridge University Press, 2008.

Garrison, Gary. A More Perfect 10. Indianapolis: Focus Publishing/R. Pullins Co, 2009. Print.

Gilmore, T.B. "The Iceman Cometh and the Anatomy of Alcoholism. Comparative Drama, Kalamazoo, MI. Vol. 18 Issue 4 Winter, 1984 . Pgs. 335 -348. Retrieved from https://login.cyrano.ucmo.edu/login?url=https://search.proquest.co 
$\mathrm{m} /$ docview/740651542?accountid=6143

Greene, Ellin, Del Negro, Janice M., Storytelling: Art and Technique, Libraries Unlimited: Santa Barbara, CA, 2010.

Guirgis, Stephen Adly. Between Riverside and Crazy. New York: Dramatists Play Service, 2015. Print.

Guirgis, Stephen Adly. The Motherfucker with the Hat. New York: Dramatists Play Service, 2011. Print.

Hatcher, Jeffrey. The Art and Craft of Playwriting. Cincinnati: Story Press, 1996.

Hudes, Quiara Alegría. Water by the Spoonful. New York: Theatre Communications Group, 2012. Print.

Jamison, Leslie. The Recovering: Intoxication and its Aftermath. Little, Brown and Company, New York, 2018. Print.

Kesslery-Harris, Alice. A Difficult Woman: The Challenging Life and Times of Lillian Hellman. Bloomsbury Press: New York, NY. 2012. Print.

LaFreniere, Nicole as told to Jessica Kowal. Cosmopolitan Magazine. "I Drove Drunk and Killed Three People,” Dec. 3, 2015. Retrieved from https://www.cosmopolitan.com/lifestyle/a50255/three-people-killed-drunkdriving-story/

Lennon, Gary. Blackout. New York: S. French, 1997. Print.

Letts, Tracy. August: Osage County. New York: Theatre Communications Group, 2008. Print. 
Inge, William. Come Back, Little Sheba. New York: Samuel French, 1950. Print.

Madison, D. Soyini. Critical Ethnography: Method, Ethics, and Performance. Thousand Oaks, CA: Sage, 2005. Print.

Macmillan, Duncan. People, Places and Things. Dramatists Play Service, Inc., 2017

"New Site: VisionsRecoveryPlay.org." Visions. N.p., n.d. Web. 08 July 2016.

O'Neill, Eugene. Long Day's Journey into Night. New Haven: Yale UP, 1956. Print.

Paul, Michelle. "People, Places and Things: Addiction, Identity and Performance.” Journal of Comparative Drama in English, Nov. 2016, Vol. 4, Issue 2. Print.

Pond, Gloria Dibble. “A Family Disease.” The Eugene O’Neill Newsletter, Vol. IX, No. 1, Spring, 1985. http://www.eoneill.com/library/newsletter/ix 1/ix-1c.htm. Accessed April 4, 2018.

Saldaña, Johnny. Ethnotheatre : Research From Page to Stage. Walnut Creek, CA: Routledge, 2011. eBook Academic Collection (EBSCOhost), EBSCOhost (accessed April 4, 2018).

Smiley, Sam. Playwriting: The Structure of Action. Yale University Press: New Haven and London, 2005. Print.

Smith, Anna Deavere. Talk to Me: Listening between the Lines. New 
York: Random House, 2000. Print.

Smith, Anna Deavere. Twilight--Los Angeles, 1992. New York, NY:

Dramatists Play Service, 2003. Print.

Twelve Steps and Twelve Traditions. New York: Alcoholics Anonymous World Services, Inc., 2014. Print.

States, Bert O. Dreaming and Storytelling. Ithaca and London: Cornell University Press, 1993. Print.

Vaccaro, Bethany. Glamour Magazine. "Drunk Driving: 'I Drove Drunk and Killed Two Sisters,"” January 2, 2011. Accessed April 12, 2018. https://www.glamour.com/story/drunk-driving-i-drove-drunk-and-killed-twosisters

"What Is the Success Rate of AA?" (n.d.). Retrieved December 17, 2017, https://americanaddictioncenters.org/rehabguide/12step/whats-thesuccess-rate-of$\mathrm{aa} /$

Williams, Tennessee. Cat on a Hot Tin Roof. New York: New Directions, 1975. Print. Wilson, Lanford. Fifth of July: A Play in Two Acts. New York, NY: Dramatists Play Service, 1982. Print.

Wright, Michael. Playwriting in Process. Newburyport: Focus Publishing/R. Pullins Company, 2010.

Vogel, Paula. How I Learned to Drive. New York: Dramatists Play Service, 1997. Print. Young, Lance Brendan. "Alcoholism and Identity: How An Alternative Framing Of Identity Can Facilitate Alcoholics Anonymous Research." Addiction Research \& Theory 19.3 (2011): 213-223. Academic Search Complete. Web. 3 Feb. 2016. 


\section{VITA}

Aaron Michael Scully is a teacher, scholar, playwright, director and actor. He earned his Ph.D. in theatre studies from the University of Missouri-Columbia. Currently, he is an Instructor of Theatre at the University of Central Missouri. Aaron teaches playwriting, screenwriting, acting, directing, theatre history and general theatre education classes. Aaron's plays have been performed in Washington D.C. Seattle, Minneapolis, Des Moines, and Columbia, MO. He is the 2017 recipient of the Planet Earth Playwriting Award and has been a semi-finalist for the Eugene O'Neill National Playwrights Conference. He received the first prize at the 2018 Little Theatre of Alexandria One-Act Contest for his play Doctor Scott which will receive its world premiere there in July.

Aaron grew up in Warrensburg, MO. He received his undergraduate degree in Hotel and Restaurant Management from Mizzou in 1998. In 2000, he moved to Los Angeles where he spent several years working as an assistant film editor in Hollywood. In 2005, he moved back to Warrensburg and became the General Manager of his family's restaurant. In 2012, he earned his MBA from UCM. During his last semester of his MBA, Aaron auditioned for a play and was cast. After participating in the production, Aaron decided to change directions and decided to pursue a Ph.D. in Theatre to teach, study and practice theatre as a career. He completed his M.A. in Theatre at UCM and recently earned his doctorate from Mizzou.

Aaron is married to Ashley Miller-Scully who is an associate professor of dance at UCM. They have two golden retrievers, Phinlan and Ophelia. Ashley and Aaron enjoy traveling, theatre, movies, sports and spending time with family and friends. 